\title{
Don José Canga Argüelles, señor despótico de vasallos
}

\author{
Manuel de Abol-Brasón y Álvarez-Tamargo \\ Universidad de Oviedo
}

CES.XVIII, núm. 19 (2009), págs. 7-72. 
Resumen: Este artículo muestra cómo uno de los ideales del Antiguo Régimen, ser señor de vasallos, estaba enraizado en la sociedad de transición al liberalismo, incluso entre los hombres ilustrados y liberales que lucharían por el cambio sociopolítico en la España de los primeros años del siglo XIX. Aludimos a la adquisición del coto jurisdiccional de Lindes por el liberal Canga Argüelles durante el reinado de Carlos IV como culminación de las diferentes estrategias matrimoniales, económicas y honoríficas de su familia a lo largo del siglo XVIII y más aún como forma de prestigio social.

Palabras clave: Hidalguía. Probanza de nobleza. Colegiata de Arbas. Coto jurisdiccional. Señor de vasallos. Desamortización. Antiguo Régimen. Ilustración. Liberalismo. Siglos XVI-XIX. 


\section{Introducción}

La falta, durante largo tiempo vivamente sentida, de una biografía rigurosa sobre nuestro economista liberal, don José Canga Argüelles ${ }^{1}$, ha sido colmada con creces, hace unos años, por la profesora Fonseca Cuevas ${ }^{2}$. La monografía que le dedicó contempla con detalle su trayectoria vital, los múltiples aspectos de su quehacer literario, político y administrativo, y lo que resulta el meollo de su aportación científica, es decir, el pensamiento económico y hacendístico ${ }^{3}$.

Hay, sin embargo, un detalle que ha pasado desapercibido a los que se han ocupado de Canga Argüelles y que ahora, en este trabajo, se va a destacar: su condición de titular señorial. Efectivamente, este prohombre de la revolución, ministro de Hacienda dos veces, una vez durante la guerra de la Independencia ${ }^{4}$ y la segunda bajo la efímera vigencia del texto constitucional gaditano, cuando el Trienio Liberal ${ }^{5}$, fue señor de un pequeño coto perdido en las montañas de Asturias, que se llamaba Lindes ${ }^{6}$. La noticia no sería sorprendente si don José lo hubiera tenido de sus mayores, como el célebre conde de Toreno, que heredó de su familia un patrimonio cuantioso, en él: el señorío de Cerredo y Degaña ${ }^{7}$. Pero

1 Resulta una aportación biográfica especialmente documentada: Ángel DE HuARTE Y JÁuREGUI, «Don José Canga Argüelles. Su vida y su obra», en José Canga ArgüElles, Diccionario de Hacienda, I, Madrid, 1968, págs. IX-XC.

2 Palmira Fonseca Cuevas, Un hacendista asturiano: José Canga Argüelles, Oviedo, Real Instituto de Estudios Asturianos (RIDEA), 1995. Véase también: Carmen García Monerris, La Corona contra la historia: José Canga Argüelles y la reforma del real patrimonio valenciano, Valencia, Universitat de València, 2004.

3 Fonseca Cuevas, Un hacendista, págs. 203-519.

4 Lo fue entre el 15 de enero de 1811 y el 6 de febrero de 1812 (Fonseca Cuevas, Un hacendista, págs. 45-48).

Fue nombrado ministro de Hacienda, secretario de Estado y del Despacho de Hacienda el 22 de marzo de 1820 (Gaceta del 23 de marzo de 1820). Tuvo la cartera hasta el 2 de marzo de 1821 (José María García Madaria, Estructura de la Administración Central (1808-1931), Madrid, Instituto Nacional de Administración Pública, 1982, pág. 295).

6 Gonzalo Anes y Álvarez de Castrillón, Los señoríos asturianos, Madrid, 1980, pág. 119. Pascual Madoz, Diccionario geográfico-estadístico-histórico de España y sus posesiones de Ultramar, X, Madrid, 1847, pág. 303, voz «Lindes (Santo Tomás)». Fermín Rodríguez GuTiÉrRez, La organización agraria de la montaña central asturiana, Oviedo, Gobierno del Principado de Asturias, 1989, págs. 270 y 317, n. 201.

7 Se trata del célebre VII conde de Toreno, don José María Queipo de Llano y Ruiz de Sarabia (1786-1843), un aristócrata adscrito sinceramente a la ideología liberal, que pertenecía a una de las familias de la nobleza de Asturias más ricas y opulentas. En los esponsales de su padre, don José Marcelino o José 
Fernando Queipo de Llano y Bernaldo de Quirós con la que sería su mujer, y madre de aquél, doña María Dominga Ruiz de Sarabia y Dávila, figura con toda la pompa de los títulos de su casa, y eso que en aquel momento todavía no había heredado el condado de Toreno. José María PataC de las Traviesas, «Apéndice III», en Luis Alfonso de Carballo, Linajes asturianos, Gijón, Auseva, 1987, pág. 83. Archivo Histórico Provincial, León (AHPL), Protocolos de León (PL), caja 762, leg. 1241, escribanía de Felipe Rodríguez de Tovar, ff. 254-257, vto.: «Capitulaciones matrimoniales otorgadas por don José de Villafañe Flórez Osorio, señor de Ferral y coronel de los Reales Ejércitos y del Regimiento de Milicias de León, en nombre de don Juan José de Eulate y Santa Cruz, caballero de la orden de Carlos III y del Consejo de Su Majestad en el de Guerra, como tutor y curador de doña María Dominga Ruiz de Sarabia Dávila Enríquez, residente en el monasterio de Santa Catalina de la Orden de Predicadores de la ciudad de León, por don Joaquín José Queipo de Llano y Quiñones Pimentel, vizconde de Matarrosa, y por don José Marcelino Queipo de Llano y Bernaldo de Quirós, hijo de este ultimo y de su esposa doña María Antonia Bernaldo de Quirós y González de Cienfuegos, en la que conciertan los esponsales de la citada doña María Dominga, hija de don Domingo Ruiz de Sarabia Neira Montenegro y Enríquez de Calatayud y de su mujer doña María Joaquina Dávila Enríquez de Cabrera, con el mencionado don José Marcelino. Real monasterio de Santa Catalina de León, 12 de noviembre de 1777», f. 254, vto.: «Don Joaquin Josef Queipo de Llano y Baldes, Quiñones, Pimentel y Yebra Doriga y Malleza, Puebla y Lugo, vizconde de Matarrosa, rexidor y alferez maior perpetuo de la villa de Cangas de Tineo en el Principado de Asturias alguacil y alcalde maior perpetuo de la Real Villa y Carcel de Ponferrada, señor de las jurisdiziones y villas de Degaña, Cerredo, Fondos de Vega de Arriba y de Abajo, de El Rebollar, Tablado, el Bao y la Sisterna en dicho Principado y de las de Tejedo, Mata de Otero y Cuebas en este reyno de Leon patrono y presentero ynsolidum de las buenas memorias y obras pias que en la iglesia parroquial de Santa Maria Magdalena doto y fundo su tío el illustrisimo señor don Fernando de Baldes, presidente que fue de Castilla y arzobispo de Granada, y asi mismo patrono y presentero de los beneficios curados de Santiago de Degaña y Santa Maria de Cerredo Santiago de Libran, y San Benito de Pardamaza su anejo, Santa Maria de Tejedo y otros». La figura del VII conde de Toreno está esperando todavía una buena biografía, a cuyo efecto hay materiales manuscritos e impresos sobrados. Resulta un personaje interesante, porque no formaba parte de una más o menos incolora nobleza, sino de la primera esfera de la hidalguía de Asturias, con notorios antecedentes en el patriciado de otras regiones españolas. Y sin embargo, a pesar de esto, su profesión constitucional es indiscutible, incluso, en ocasiones, con formulaciones bastante extremistas. Su hijo, el VIII conde, don Francisco de Borja, sería un prócer conservador, muy alejado de las demasías liberales de su antecesor. Es una trayectoria que recorrieron numerosos personajes y bastantes familias del patriciado. Cfr. Joaquín Varela Suanzes-Carpegna, El conde de Toreno (1786-1843). Biografía de un liberal, Madrid, Marcial Pons, 2005, págs. 31, 54 y 262. Esta aproximación biográfica, más que biografía —posee escasa apoyatura documental—, sin embargo tiene algunos errores de perspectiva histórica: afirma que el VII conde de Toreno nació cuando reinaba Carlos IV, siendo que en 1786 el soberano español era Carlos III. Por otra parte asegura que el primer Consejo de Regencia, formado en 1810, estaba integrado por «Francisco de Saavedra, obispo de Orense, Antonio Escaño, el general Castaños y Miguel de Lardizabal». Cualquier lector medianamente informado sabrá que Saavedra no era el ordinario orensano, y que el miembro del organismo que tenía esta dignidad se llamaba don Pedro de Quevedo y Quintano — pontificó en la diócesis gallega entre 1776 y 1818 - , personaje famoso que no puede pasar desapercibido para los estudiosos, por su realismo y sus extraordinarias cualidades morales y pastorales. Es más, el error es reiteradamente cometido según se indica en el índice. Don Francisco de Saavedra y Sangronis fue hombre casado: contrajo matrimonio el 17 de noviembre de 1788 con doña Rafaela Jaureguihondo, camarista de la entonces princesa de Asturias, doña María Luisa de Borbón Parma. Dejó interesantes escritos, que lo son, habida cuenta su trayectoria y protagonismo políticos durante los reinados de Carlos III y Carlos IV y en tiempos de la Francesada. Su retrato más famoso se debe a Goya. Cfr. Varela Suanzes-Carpegna, «Estudio preliminar», en Conde de Toreno, Discursos parlamentarios, Oviedo, JGPA, 2003, págs. XXv y XLIII. Archivo Histórico Nacional de Madrid (AHN), Estado, Orden de Carlos III, exp. 138: «Pruebas de don Francisco de Saavedra y Sangronis, oficial de la Secretaría de Indias», 1782. Francisco de SAAVEDRA, Los decenios. Autobiografía de un sevillano de la Ilustración, Sevilla, Ayuntamiento de Sevilla, 1995, págs. 303-305 (testamento de don Francisco de Saavedra, Sevilla, 20 de marzo de 1817) y 307-320 (memoria testamentaria de don Francisco de Saavedra, Sevilla, 30 de enero de 1805-6 de marzo de 1814). Francisco Morales Padrón, «Introducción», en SaAvedra, Los decenios, págs. 
no es éste el caso que nos ocupa. Canga Argüelles fue señor por voluntad propia y mediante una de aquellas discutidas operaciones desamortizadoras que tuvieron lugar a caballo entre los siglos XVIII y XIX, casi siempre durante el reinado de Carlos IV ${ }^{8}$. Resulta por lo tanto llamativo que uno de los impugnadores más característicos de la antigua monarquía, y en consecuencia del régimen señorial — también acosado por los ilustrados ${ }^{9}$-, se quisiera convertir en prócer a la vieja usanza, como los añejos mayorazgos de Asturias —Quiroses, Mirandas, Valdeses, Navas, Pradas o Navias ${ }^{10}$ — que conservaron hasta el primer tercio del siglo XIX la titularidad de sus cotos y jurisdicciones ${ }^{11}$.

Esta tardía transfiguración era un evidente anacronismo. El régimen señorial formaba parte de aquel denostado feudalismo que atraía las filípicas liberales ${ }^{12}$ y al que incluso la monarquía ilustrada le había mostrado una franca anti-

9-21. Miguel Artola, La España de Fernando VII, Madrid, Espasa-Calpe, 1999, págs. 339-350. Francisco Martí Gilabert, La Iglesia en España durante la Revolución francesa, Pamplona, Universidad de Navarra, 1971, págs. 93, 225, 284-285, 296, 304 y 310-313. Juan Manuel BEDOYA, Retrato histórico del eminentísimo excelentísimo e ilustrísimo señor don Pedro de Quevedo y Quintano, Madrid, 1835. Eugenio LóPEz AydiLlo, El obispo de Orense en la Regencia del año 1810. Planteamiento de los problemas fundamentales de la vida constitucional de España, Madrid, 1918.

8 Marta Friera Álvarez, La desamortización de la propiedad de la tierra en el tránsito del Antiguo Régimen al liberalismo, Gijón, Fundación Foro Jovellanos del Principado de Asturias, 2007. Se trata de un estudio sobre todo formal. Resulta fundamental para comprender esta operación el estado de la propiedad y la fiscalidad eclesiásticas al final del Antiguo Régimen y la contribución del clero a la Hacienda Real, aspectos éstos sin los cuales aquélla resulta deficitariamente explicada. Estos temas han sido esbozados con sumariedad por Martí Gilabert, La Iglesia en España, págs. 219-256.

9 Antonio domínguez orTiz, Sociedad y Estado en el siglo XVIII español, Barcelona, Ariel, 1976, págs. 429-453. Richard Herr, España y la revolución del siglo XVIII, Madrid, Aguilar, 1975, págs. 79-80, 94 y 371.

10 Cfr. María Ángeles FaYA DíAz, Los señoríos eclesiásticos en la Asturias del siglo XVI, Oviedo, RIDEA, 1992, págs. 381-390.

11 Anes y Álvarez de Castrillon, Los señoríos, págs. 22-25.

12 Salvador De Moxó, La disolución del régimen señorial en España, Madrid, Consejo Superior de Investigaciones Científicas, 1965. José CANGa ArgüElles, Elementos de la ciencia de hacienda, Madrid, 1961, pág. 39: «En los siglos calamitosos de la feudalidad los pequeños caciques que oprimían a los pueblos, disputando no pocas veces la autoridad al monarca, llenaron de trabas el comercio»; pág. 50: «Los autores de los fueros de Cuenca, Sepúlveda, Alarcón, Consuegra, Alcaraz, Baza y Plasencia, al explicarse en estos términos, descubrieron bien a las claras lo distantes que estaban de impedir los cierros de los terrenos, ni de conceder a otro el derecho privativo de construir hornos y molinos, que disfrutan los señores baronales con daño de la agricultura»; págs. 129-131: «Pertenecen a esta clase (contribuciones que recaen sobre los productos de los capitales) los diezmos, las primicias, los derechos feudales, la contribución territorial y mobiliaria, y la que recae sobre el alquiler de las casas, sobre los censos y sobre los intereses de la deuda publica [...]. Con los nombres de diezmo, primicia y derechos feudales se cobra un 3, 5, 6 o 10 por ciento del producto de las tierras, en el momento de la cosecha, sin deducción de gastos de cultibo. Estas contribuciones imponen el sacrificio sobre una clase de productores con exclusión de los demás; desnivelan la justicia, en el hecho de no compartirse con proporción a las ventajas del contribuyente; atacan los capitales y hacen desfallecer la industria; porque igual cantidad paga el que cultiva frutos que exigen una grande anticipación de fondos y de trabajo, que el que se dedica a la producción de objetos de corto coste [...]. Las ventajas mezquinas de un corto número de hombres que mantienen su opulencia a costa del abatimiento del labrador han impedido hasta aquí la reforma de los derechos feudales, los cuales, adoleciendo de los mismos vicios que el diezmo y la primicia, han merecido 
patía $^{13}$. El curso de los acontecimientos presagiaba que tenía los días contados. Si en teoría era una seria cortapisa al concepto de «Estado» que por entonces formulaba el constitucionalismo, en la práctica tenía muy pocas posibilidades de perseverar, cuando incluso los propios nobles lloraron muy poco su pérdida en cuanto a los aspectos públicos ${ }^{14}$. Pero es evidente que en medio de aquella tremenda confrontación de ideas que supuso el tránsito del viejo orden al nuevo se entremezclaron, incluso en estos prebostes apasionados del credo liberal, otros aspectos que nada tenían que ver con la supuesta pureza de su pensamiento político y que incluso lo contradecían abiertamente. A veces, sin nada que ver con las prédicas políticas o parlamentarias, los comportamientos iban por otros derroteros. Se trata del eterno deseo del hombre por ascender en su condición socioeconómica, aunque ello sea sacrificando los ideales.

Un defecto que tradicionalmente se ha achacado a los españoles es su propensión a imitar los usos nobiliarios y a introducirse, por las buenas o por las malas, en el estamento patricio ${ }^{15}$. Parece que esta tendencia sólo era propia de aquellos tiempos dorados en los que el sol no se ponía en los dominios españoles y que al llegar, primero los filósofos y después los revolucionarios, se amortiguó o quedó relegada a unas minorías anacrónicas y trasnochadas. Un noble señor de Asturias, caballero de la orden de Malta ${ }^{16}$, don Juan Antonio Suárez de la Granda $^{17}$, convertido al liberalismo, en 1820 lamentaba que su casa no tuviera escudo:

[...] para que arrancándole como un signo de la preocupación caballeresca de los tiempos quijotescos, pudiese substituir su hueco ese precioso monumento [la

el nombre de bárbaros, por que destruyen la agricultura; y ponen obstáculos invencibles al establecimiento de un sistema bien organizado de hacienda»; págs. 140-141: «Cerca de cuatrocientos años han transcurrido desde que las provincias de la península española que obedecían a monarcas diferentes se unieron bajo la mano de uno solo: y al cabo de tanto tiempo, no se ha logrado establecer un plan de hacienda, que fundado sobre bases uniformes descubra una unidad de principios. Compuesto de contribuciones, unas de origen romano; otros de estirpe agarena; algunas fundadas sobre las ideas libres; no pocas derivadas de la feudalidad; varias que han debido su fatal nacimiento al genio desolador de los arrendadores y arbitristas extranjeros; y no pocas que fueron recursos estraordinarios adoptados en el conflicto de las urgencias momentáneas, los cuales debiendo cesar con la variación de las circunstancias se han perpetuado desgraciadamente: forman un cuerpo dislocado de elementos heterogéneos y una combinacion monstruosa, ajena de las máximas económicas».

13 Domínguez Ortiz, Sociedad, pág. 431.

14 Moxó, La disolución, págs. 20-58 y 147-178.

15 Cfr. Alfonso de Figueroa y Melgar, «Los prejuicios nobiliarios contra el trabajo y el comercio en la España del Antiguo Régimen», Cuadernos de Investigación Histórica, 3, (1979), págs. 415-436. Julio ÁlvAREZ Rubio, Profesiones y nobleza en la España del Antiguo Régimen, Madrid, 1999.

16 AHN, Órdenes Militares (OM), San Juan de Jerusalén, exp. 23 601: Pruebas de don Juan Antonio Suárez de la Granda Robledo Vitorero y Toro (1798).

17 José Antonio Fidalgo Sánchez, «Prólogo», en Juan Antonio SuÁrez Victorero, Descripción geográfico-histórica del concejo de Colunga, Gijón, 1985, págs. XI-XXII. 
lápida de la Constitución], que ha de transmitir a las más remotas generaciones el recobro de nuestros derechos, y el suceso más heroico de la nación española ${ }^{18}$.

Esto parecía ser lo consecuente para aquellos fanáticos del constitucionalismo. Sin embargo no fue siempre así, y esta estridente investidura de Canga Argüelles convertido en titular señorial, y así, todavía en pleno Trienio Liberal, convence de que, como dice el refranero, una cosa era predicar y otra dar trigo. Al fin y al cabo, el liberalismo no habría de consolidarse sino mediante la promoción de unos pocos, aunque ello supusiera la discriminación de los intereses comunes del cuerpo social. La magia del denominado progreso y de la idolatrada libertad tiene también aspectos sórdidos.

\section{Nobleza ilustre pero modesta}

Gracias, sobre todo, a las pruebas de nobleza para ingresar en la orden de Carlos III de don José Canga Argüelles ${ }^{19}$ y de su padre don Felipe ${ }^{20}$, se puede conocer con minucioso detalle la hidalga condición de ambos por los cuatro costados. Aunque es seguro que ni uno ni otro mostraron apreciable deferencia por los principios caballerescos que, como un auténtico fósil, todavía pervivían en las postrimerías del Antiguo Régimen ${ }^{21}$, lo cierto es que estas informaciones se realizaron con un sorprendente derroche de exclusivismo nobiliario $^{22}$. En las de don Felipe Ignacio, de 1797, se forzaron hasta

18 Alberto Montero Prieto, El valle de Cuna a través de los tiempos, Mieres del Camino, 1995, págs. $147-148$.

19 AHN, Estado, Carlos III, exp. 1309: Pruebas de don José Canga Argüelles y Cifuentes Prada, nombrado caballero de la orden de Carlos III por decreto de 18 de octubre de 1805. Se realizó la información en Oviedo, Gijón, Villaviciosa y Madrid y fue aprobada el 22 de marzo de 1806.

20 AHN, Estado, Carlos III, exp. 1032: Pruebas de don Felipe Ignacio Canga Argüelles y Pérez de la Sala, nombrado caballero pensionista de la orden de Carlos III por decreto de 27 de junio de 1797. Se realizó la información en Oviedo, Gijón, Langreo y Madrid y fue aprobada el 7 de diciembre de 1797.

21 Domínguez Ortiz, Sociedad, págs. 345-358.

22 La genealogía de don Felipe Canga Argüelles, en sus pruebas, se testimonia con sumo rigor hasta los segundos abuelos: pretendiente: don Felipe Canga Argüelles, natural de Oviedo; padres: José Canga Argüelles, natural de Oviedo, y María Pérez de la Sala, natural de Gijón; abuelos paternos: Ambrosio Canga Argüelles y Catalina de las Riestra, naturales de Oviedo; abuelos maternos: Adriano Pérez de la Sala, natural de la parroquia de San Andrés de los Tacones (Gijón), y Catalina Amado, natural de la parroquia de San Salvador de Deva (Gijón); segundos abuelos paternos-paternos: Tomás Canga Argüelles, natural de Ciaño (Langreo), y María García de Villar, natural de Guimarán (Carreño); segundos abuelos paternos-maternos: Bernabé de la Riestra y Francisca Álvarez de Otero, naturales de Oviedo; segundos abuelos maternos-paternos: Alonso Pérez, natural de la parroquia de San Andrés de los Tacones, e Inés González Bango, natural de la villa de Avilés; segundos abuelos maternos-maternos: Pedro Amado e Isabel García, naturales de la parroquia de Deva. Igual ocurre con los ascendientes de don José Canga Argüelles: pretendiente: don José Canga Argüelles, natural 
el máximo los testimonios que mostraban la precedencia de la estirpe, más allá, incluso, de la simple prueba nobiliaria. Se demostró cómo los Canga Argüelles eran patronos y presenteros del beneficio curado de San Martín del Rey Aurelio en su calidad de descendientes de uno de los solares más antiguos de la comarca, la casa de Lai ${ }^{23}$. Y también se probó documentalmente que los Pérez de la Sala ejercían igual patrocinio en el curato de San Andrés de los Tacones, en virtud de su oriundez en la casa de San Andrés o de la Reboira, en el solar de los Pérez, y en nada menos que el castillo de Jepeláez, otras de las matrices insignes del concejo de Gijón, que a la sazón poseía don Fernando de Valdés Solís, maestrante de Granada ${ }^{24}$. Unos de los tatarabuelos del hacendista, Pedro Amado, e Isabel García resultaban oriundos de la casa solariega de los Ramírez de Deva, y por ende parientes del marqués de San Esteban del Mar:

[...] que el don Pedro Amado y su muger doña Ysabel Garcia provienen de la casa solariega de Ramirez de Deba que ha dado como la de Valdes tantos hombres ylustres en letras y armas y es esta la que goza en la actualidad don Manuel Ramirez marques de San Esteban señor del coto y jurisdicion de Natahoyo, theniente coronel de ynfanteria, y comandante de las armas de este puerto, y mas de la costa de Asturias ${ }^{25}$.

En esta ocasión se infló tanto la calidad del linaje que uno de los testigos, don Ramón de Solís Antayo, alférez mayor de Oviedo y señor de las torres de la

de Oviedo; padres: don Felipe Canga Argüelles, natural de Oviedo, y doña Paula de Cifuentes Prada, natural de Gijón (la genealogía paterna ya estaba probada en la información de su padre); abuelos maternos: Juan Francisco de Cifuentes Prada y María Francisca Fernández Mieres, naturales de Gijón; segundos abuelos maternos-paternos: Francisco de Cifuentes Prada y Ángela García, naturales de Gijón; segundos abuelos maternos-maternos: Antonio Fernández Mieres, natural de Villaviciosa, y Manuela Menéndez Valdés, natural de Gijón. AHN, Estado, Carlos III, exp. 1032, s. f.: Índice de pruebas y árbol genealógico. Ibídem, exp. 1309, s. f.: Î́ndice de pruebas y árbol genealógico.

23 Ibídem, exp. 1032, ff. 44 vto.-70 vto.: Diligencias realizadas en el archivo del Tribunal Eclesiástico de Oviedo sobre el beneficio curado de San Martín del Rey Aurelio (Langreo), Oviedo, 14-16 de septiembre de 1797. Esta pieza eclesiástica era de presentación de los descendientes de las casas de Pumarabín, Sanfrechoso, Sienra y Lai. El titular de la primera de ellas en el siglo xvIII era el marqués de Camposagrado, uno de los próceres de mayor representatividad en la región.

24 Ibídem, exp. 1032, ff. 70 vto.-84: Diligencias realizadas en el archivo del Tribunal Eclesiástico de Oviedo sobre el beneficio curado de San Andrés de los Tacones (Gijón), Oviedo, 16-18 de septiembre de 1797; ff. 120 vto.-122: Testimonio de don Mateo Antonio García Sala, Gijón, 12 de septiembre de 1797; f. 121: «Que dicho señor fiscal como descendiente por su madre de la casa solariega de la Reboria y castillo de Xepelaez en dicha parroquia de San Andres que posehe actualmente don Fernando de Valdes Solis maestrante de Granada tiene voz y presentacion en dicho curato de San Andres siempre que subceda bacante».

25 Ibídem, exp. 1032, ff. 119-120: Instancia presentada por don José Cifuentes Prada, presbítero, vecino de Gijón. Gijón, 12 de septiembre de 1797. 
Quintana en Ciaño, Langreo, depone que «sabe y le consta que las familias de Canga y Argüelles son de las mas antiguas de este conzejo ${ }^{26}{ }_{»}$.

La información de don José fue menos detallista, porque pocos años antes había probado todo el costado masculino su padre, pero aun así el informante no se reprimió lo más mínimo y rascó papelorios hasta la saciedad, con lo que los puntos rumbosos del linaje materno no resultaron menos que los de los Canga Argüelles. La familia de la madre del economista, doña Paula Cifuentes Prada y Fernández de Mieres, era de lo más insigne:

Asi mismo sabe y le consta que la referida doña Pabla, su padre y abuelos provienen de la casa y torre que llaman de San Nicolas de la Arena y en la que recayeron todos sus primogénitos como lo es oy don Miguel de Zifuentes Prada regidor perpetuo de esta villa quien como subcesor en la dicha casa se halla gozando varias regalías como son entre otras la presentación de una capilla en el combento de Santo Domingo de Oviedo y la de tener en esta parroquia (San Pedro de Gijón) varias sepulturas como descendiente de Suero Gonzalez Zifuentes, de cuio veneficio disfrutan todos sus parientes ${ }^{27}$.

Los Cifuentes eran una de las familias más veteranas de la nobleza de Gijón. De ella había salido el célebre jurisconsulto y comentarista de las leyes de Toro, Miguel de Cifuentes ${ }^{28}$. A finales del xvi habían mostrado no sólo una llamativa vanidad por su hidalguía, sino también por su limpieza, tanta, que sus humos ofendieron al patriciado de Oviedo y provocaron un serio incidente entre los nobles de la capital del Principado ${ }^{29}$.

No hay que poner en duda los vínculos biológicos de la prosapia del economista con gentes tan conspicuas, pero eran tan lejanos que sólo las exigencias de los estatutos de la orden y, sobre todo, el orgullo desmedido de los Canga Argüelles, los sacaron a la luz, porque evidentemente la línea de don José no podía ostentar aquellas grandezas. Sus antepasados no eran personajes conocidos de la sociedad asturiana, sino individuos comunes que vivían al socaire de

26 Ibídem, exp. 1032, ff. 116-116 vto.: Testimonio de don Ramón de Solís Antayo. Sama (Langreo), 11 de septiembre de 1797.

${ }_{27}$ Ibídem, exp. 1309, ff. 26 vto.-28: Testimonio de don Mateo García Sala, regidor perpetuo que fue de Gijón y vecino de esta villa. Gijón, 28 de diciembre de 1805.

28 No se sabe mucho de este jurista, fallecido en Oviedo por el año 1566, que resulta ser antepasado de don José Canga Argüelles. Aunque se le atribuyen diversas obras, no siempre localizables, la más importante versa sobre las leyes de Toro: Miguel de Cifuentes, Glosa de Cifuentes. Nova lectura sive declaratio legum Taurinorum edita a Michaele de Cifuentes civi ovetensi: et naturali ratione originis ville de Gijon, Salamanca, Juan de Junta, 1546.

29 Cfr. María Pilar García Cuetos, El convento dominicano de Nuestra Señora del Rosario de Oviedo. Historia y arquitectura, Oviedo, RIDEA, 2001, págs. 46-47 y 105-14. 
los grandes linajes, como el de los marqueses de Camposagrado o el de los riquísimos Valdés de Gijón ${ }^{30}$. Por eso es casi inaudito verlos ahora en los tiempos finales del Antiguo Régimen, cuando en Francia ya habían cortado la cabeza a los reyes y sometido a la aristocracia a la más sanguinaria de las persecuciones, regodearse con tanto aliento en las viejísimas glorias familiares y ocultar la condición útil y laboriosa de sus deudos inmediatos. Es como si en vísperas de la Francesada y de la obra constitucional de Cádiz, las consecuencias de la Ilustración y el esbozo del igualitarismo apenas los hubieran arañado. Parece probable que, habida cuenta sus orígenes menestrales, hubieron de sufrir más de una afrenta, como al parecer le ocurrió al conde de Floridablanca por ser hijo de un papelista ${ }^{31}$.

La trayectoria de los Canga Argüelles, a partir de la segunda mitad del siglo XVIII, es un emblemático arquetipo de la superación por el aprendizaje y la cultura. Se trata de un producto típico de la Ilustración, pero no tanto porque haya alcanzado una notable posición desde los círculos apocados de la sociedad provinciana, que esto había ocurrido siempre. Lo que merece ser notado es que a partir de los ambientes artesanales de una ciudad levítica y aristocrática, que era el Oviedo de entonces, los Canga Argüelles se lanzaron al alto mundo de la política y la magistratura con un pensamiento reformista primero y liberal después. Este salto portentoso hubo de conjurar los prejuicios sobre la cuna y el ejercicio de los oficios mecánicos que todavía estaban presentes en la mentalidad social, y se produjo en un tiempo relativamente breve. Tan excelente carrera comenzó en el reinado de Carlos III y continuó en el tiempo sucesivo: don Felipe Ignacio, tras ser catedrático de prima de leyes en la Universidad de Oviedo y fiscal en la Audiencia de Zaragoza, el 19 de agosto de 1792 era nombrado fiscal del Consejo de Castilla, y diez años después, el 7 de septiembre de 1802, consejero del mismo ${ }^{32}$. Su hijo don José, el 3 de marzo de 1798 recibía una oficialía en la secretaría de Hacienda ${ }^{33}$, el 11 de octubre de 1804 la contaduría principal del Ejército de Valencia y Murcia ${ }^{34}$ y en 1811 la secretaría de Estado y del Despacho de Hacienda ${ }^{35}$.

Los Canga Argüelles procedían de Villa de Sama, en la parroquia langreana de San Esteban de Ciaño, en donde nació su tercer abuelo, Tomás, un huérfano que, seguramente en búsqueda de fortuna, trasladó su domicilio a

30 Véanse documentos citados en las notas 23 y 24.

31 Domínguez Ortiz, Sociedad, pág. 319.

32 Santos Manuel Coronas GonzÁLEZ, Ilustración y derecho. Los fiscales del Consejo de Castilla, Madrid, 1992, pág. 254.

33 Fonseca Cuevas, Un hacendista, pág. 37.

34 Ibídem, pág. 41.

35 Ibídem, págs. 45-46. 
Oviedo en la segunda mitad del siglo XVII y que hizo información de su calidad en $1668^{36}$.

Pero no era lo mismo formar parte de la élite en los discretos entornos rurales e hidalgos del valle del Nalón que situarse con el mismo tono en la capital del Principado, donde había que codearse con la aristocracia civil y eclesiástica de la tierra, en sus auténticos palacios, sedes de provincianas cortes y rodeadas de un enjambre de servidores o plumíferos ${ }^{37}$. Por eso la circunstancia inicial de los Canga Argüelles en Oviedo no trascendió la rutina de una vida ordinaria y menestral, condición por otra parte muy corriente entre la nobleza de la tierra. El abuelo paterno del hacendista, José, era un maestro cerero, confitero y minorista que vivía en la calle de Jesús ${ }^{38}$, y así aparece en el catastro de Ensenada:

Jose Canga Argüelles hijodalgo de cinquenta y seis años casado con Ana Maria Perez, tiene en su casa a Phelipe Lazara y Josepha menores sus hijos y a Isabel Suarez su criada, que la da de comer y sesenta y seis rreales al año, es maestro zerero y confitero porque le regulan las ganancias ochocientos rreales al año. Es tratante y mercader de por menor, y por el capital de sesenta mil rreales vellón le consideran de intereses a un diez por ciento seis mil y por tratante en vino para vender por menor tres mil rreales vellón que todo haze nueve mil y ochocientos ${ }^{39}$.

La descripción de su casa era la correspondiente a su actividad mercantil ${ }^{40}$. Tenía en ella, además, dos yeguas, dos potros y dos crías de cerdo. No consta

36 AHN, Estado, Carlos III, exp. 1032, ff. 14 vto-25 vto.: Justificación de hidalguía de Tomás Canga y Argüelles, Oviedo, 14 de mayo de 1668-Vega de Linares (Langreo), 7 de junio de 1668. Tomás Canga y Argüelles era hijo de Juan Canga (empadronado noble en Langreo en 1639 y 1644) y de doña Catalina de Argüelles, su mujer; y nieto por línea paterna de Domingo Canga (empadronado noble en 1596, 1608 y 1635) y de su esposa María Canga, todos vecinos de Villa de Sama (Langreo). Se casó el 19 de julio de 1661 con María García de Villar en la ovetense parroquia de San Tirso. En esta misma iglesia fue bautizado el 9 de febrero de 1666 Ambrosio, bisabuelo del hacendista. Ibídem, exp. 1032, ff. 30-33 vto.: Compulsa de las partidas sacramentales en las parroquias de San Tirso y San Isidoro de Oviedo. Oviedo, 11-12 de septiembre de 1797.

37 Una descripción pormenorizada del vecindario de Oviedo a principios del siglo XVIII: José Ramón Tolivar Faes, Oviedo, 1705, Oviedo, Diputación Provincial, 1981.

38 Archivo del Ayuntamiento de Oviedo (AAO), B-44, doc. 8: Padrón de vecinos de la ciudad de Oviedo del año 1751, f. 21 vto.: Parroquia de San Tirso El Real, calle de Jesús: «Jose Canga Argüelles y Phelipe su hixo hixodalgo».

39 AAO, B-128, Obiedo. Tomo 1. Ciudad de Oviedo y su concejo. Copia del Libro Segundo de Seglares, Oviedo, 30 de mayo de 1753, f. 206-206 vto.

40 AAO, B-132, Respuestas particulares. Oviedo. Tomo 5, f. 3468-3468 vto.: «Casa tiene en la que vive que se compone de portal y en el una tienda, bodega y cavalleriza, sus dos altos se componen de dos cozinas dos salas y mas oficinas confronta de oeste casa de don Francisco Moran Valdes, de poniente casa de doña Maria de Villar, de mediodia calle publica y de norte huerta de don Bernardo de Quiros y Benabides, y si se arrendara fuera en diez y ocho ducados vellon. Carga. Paga a las monjas agustinas de la villa de Jijon los reditos de un zenso principal de doscientos ducados a razon de tres por ciento que sobre sus vienes tiene cargado». 
poseyera otros bienes raíces que su vivienda, en el concejo de Oviedo. En los de Corvera y Riosa, y en el coto de Valdedios, disponía de cuarenta y seis cabezas de ganado mayor dado en aparcería, señal de que los beneficios del negocio le permitían algunas inversiones ${ }^{41}$. El hermano de José, Jerónimo, vivía en la calle de Santo Domingo ${ }^{42}$ y era de oficio chocolatero ${ }^{43}$.

Pero, como ocurrió en otros muchos casos, las letras hicieron despegar a esta familia desde las modestas posiciones del patriciado urbano al estado de los burócratas y gobernantes. El momento histórico era propicio para ascensos fulgurantes. La sociedad del Antiguo Régimen ofrecía señales evidentes de descomposición y estancamiento, y no se podía enfrentar con éxito a los desafíos y las necesidades de la época. La vieja nobleza, en gran parte, se mostraba inerte y escasamente compatible con los cambios precisos en el orden social y en el económico. Acaso su fragilidad cultural y el exacerbado criticismo de que fue objeto le hizo perder su propia autoestima y el significado de funcionalidad social que siempre la había caracterizado ${ }^{44}$.

En tal situación, estos pequeños hidalgos, validos de su formación literaria y con escaso interés por el mantenimiento a ultranza del viejo orden, cumplieron el papel de ofrecer el vigor suficiente al arraigo del liberalismo ${ }^{45}$. De esta nobleza sin grandes alardes no sólo surgió Canga Argüelles, sino también don Alejandro Mon ${ }^{46}$ o su cuñado don Pedro José Pidal ${ }^{47}$.

Así, el único hijo varón del confitero no siguió el oficio de su padre. Don Felipe estudió leyes y cánones y terminó siendo consejero de Castilla ${ }^{48}$. Este caballero fue una figura notoria de la Ilustración. No hay duda por lo tanto de que los Canga Argüelles pasaron del horno de los confites a la palestra de la intelectualidad, en un tiempo en el que la novedad de las ideas poseía un atractivo vigoroso y eficaz.

41 AAO, B-132, Respuestas particulares. Oviedo. Tomo 5, ff. 3469 vto.-3470.

42 AAO, B-44, doc. 8, Padrón de vecinos de la ciudad de Oviedo del año 1751, f. 40: Parroquia de San Isidoro, calle de Santo Domingo: «Geronimo Canga Argüelles hixodalgo, Santos, Bizente y Lazaro sus hijos lexitimos hijosdalgo».

43 AAO, B-128, Obiedo. Tomo 1, Oviedo, 30 de mayo de 1753, ff. 205 vto.-206: «Geronimo Canga Argüelles hijodalgo de treinta y cinco años casado con Theresa Piñero tiene en su casa a Santos Vizente Lazaro y Maria menores sus hijos su oficio chocolatero y le regulan de ganancias quinientos veinte rreales al año».

44 Jean Sarrailh, La España ilustrada de la segunda mitad del siglo XVIII, Madrid, 1974, págs. 87-89.

45 Lo mismo se puede decir de algunos ilustrados asturianos como Campomanes. Senén González Ramírez, Hidalgos de armas poner y pintar en el concejo de Tineo (estudio genealógico), Oviedo, 1996, págs. 290-298. González Ramírez, Pequeños anales de la feligresía de Santa Eulalia de Sorriba natalicia del conde de Campomanes, Salas, 2002, págs. 130-135.

46 Manuel de Abol-Brasón y Álvarez-Tamargo, «Alejandro Mon: los ascendientes familiares y su primera época ovetense», Alejandro Mon. Hacienda y política en la España isabelina, Oviedo, 2003, págs. XXV-XL. $216-226$.

47 Constantino SuÁrez, Escritores y artistas asturianos. Índice biobliográfico, VI, Oviedo, 1957, págs.

48 Fonseca Cuevas, Un hacendista, págs. 25-26. 
Fue a raíz de este salto, consecuencia del propio esfuerzo y de la voluntad por superarse, cuando estos añejos hidalgos comenzaron a ser conocidos con el título de don. En el momento en el que, en 1797 y en 1805, se hicieron las pruebas para la orden de Carlos III de don Felipe y su hijo don José, se tuvo que realizar un minucioso examen de los padrones de distinción de estados de sus antepasados, en donde figuran alistados sin más seña que sus nombres y apellidos ${ }^{49}$. Pero entonces una mano interesada cometió un pequeño fraude en la información, intrascendente jurídicamente pero muy expresivo, según la mentalidad aburguesada que entonces se iba imponiendo: les puso el consabido don, que nada añadía a la nobleza pero que convertía al confitero de la calle de Jesús y a sus ascendientes en unos vecinos campanudos con pinta de señorones ${ }^{50}$. El título de don llegaría tardíamente, cuando la prole y la familia del pastelero se iban situando con ventaja en la sociedad ovetense, pero semejante distinción no alcanzó a otras ramas de la estirpe, menos afortunadas ${ }^{51}$. En las pruebas, no obstante, se empleó con prodigalidad.

49 AAO, B-45, Padrón de la ciudad de Oviedo del año 1705. Feligresía de San Tirso, calle de Solazogue, f. 19: «Ambrosio la Canga Argüelles Joseph Antonio y Marcos sus hijos hijosdalgo». AAO, B-44, doc. 2, Padrón de la ciudad de Oviedo de 1710. Feligresía de San Tirso, calle de Solazogue, f. 9: «Ambrossio Canga Argüelles; Joseph; Antonio y Bernardo sus hixos hixosdalgo». Ibídem, doc. 3, Padrón de la ciudad de Oviedo de 1717. Feligresía de San Tirso, calle de Solazogue, f. 4: «Ambrosio de la Canga Argüelles, Joseph Antonio, Marcos Antonio, Luis Bernardo, Gregorio y Geronimo sus hijos lexitimos hijosdalgo». Ibídem, doc. 5, Padrón de la ciudad de Oviedo de 1732. Feligresía de San Tirso, calle de Jesús, f. 17 vto.: «Joseph Canga Argüelles hijodalgo». Ibídem, doc. 6, Padrón de la ciudad de Oviedo de 1737. Feligresía de San Tirso, calle de Jesús, f. 22: «Jose Canga Argüelles hijodalgo Antonio ausente y Geronimo hermanos hijosdalgo». Ibídem, doc. 7, Padrón de la ciudad de Oviedo de 1744. Feligresía de San Tirso, calle de Solazogue, f. 12: «Antonio Canga Argüelles hermano de Joseph Canga Argüelles que vive en la calle de Jesus hijodalgo»; calle de Jesús, f. 21: «[Al margen: Noble] Joseph Canga Argüelles hijodalgo Phelipe su hijo legitimo hijodalgo»; feligresía de San Isidoro, calle de Santo Domingo, f. 36 vto.: «Geronimo Canga Argüelles hijodalgo, Santos y Bicente sus hijos lexitimos, hijosdalgo». Ibídem, doc. 8, Padrón de la ciudad de Oviedo de 1751. Feligresía de San Tirso, calle de Solazogue, f. 12: «Antonio Canga Argüelles hijodalgo»; calle de Jesús, f. 21 vto.: «Jose Canga Argüelles y Phelipe su hixo legitimo hixodalgo»; feligresía de San Isidoro, calle de Santo Domingo, f. 40: «Geronimo Canga Argüelles hixodalgo, Santos, Bicente y Lazaro sus hijos lexitimos hijosdalgo». AAO, B-47, doc. 1, Borrador del padrón de la ciudad de Oviedo del año 1766. Feligresía de San Tirso, calle de Jesús, f. 11: «Joseph Canga Argüelles y Phelipe su hijo»; Padrón de la ciudad de Oviedo del año 1766. Feligresía de San Tirso, calle de Jesús, f. 83: «Jose Canga Argüelles, y don Phelipe su hijo lexitimo hijosdalgo»; feligresía de San Isidoro, calle de Santo Domingo, f. 103: «Geronimo de Canga Argüelles sus hijos Vizente y Lazaro hijosdalgo».

50 AHN, Estado, Carlos III, exp. 1032, ff. 12-14 vto.: Compulsa de los padrones de la ciudad de Oviedo en los que figuran los Canga Argüelles desde el año 1664 hasta el de 1794. Oviedo, 9 de septiembre de 1797.

51 AAO, B-47, 2, Padrón de la ciudad de Oviedo del año 1773. Feligresía de San Tirso, calle de San Francisco, f. 11: «El doctor don Phelipe Ygnacio Canga Argüelles y su hixo Joseph hijodalgo»; calle de Jesús, f. 13 vto.: «Don Joseph Canga Argüelles hijodalgo»; f. 14: «Maria Theresa Gonzalez Piñera, viuda de Geronimo Canga Argüelles, sus hijos Santos, casado en Gixon, y Vizente; dicho Santos, Vicente y Joseph Antonio hixosdalgo»; «Doña Josepha Canga Argüelles viuda de don Gregorio Blason sus hixos, Ignazio, y Francisco hixosdalgo». Ibídem, 3, Padrón de la ciudad de Oviedo del año 1780. Feligresía de San Tirso, calle de los Pozos, f. 15 vto.: «El doctor don Phelipe Ygnazio Canga Argüelles cathedratico de Prima de Leyez en esta Unibersidad, sus hijos don Joseph y don Bernave hijosdalgo»; calle de Jesús, f. 17 vto.: «Doña Josefa Canga 
Naturalmente en ningún momento de las probanzas figura el oficio de pastelero, pues incluso en la recientemente fundada orden de Carlos III también terminaron por imponerse los escrúpulos en materia de limpieza de oficios ${ }^{52}$. Todos los testigos deponen la pulcritud de empleos de los antepasados de los pretendientes por los cuatro costados ${ }^{53}$.

Cuando los Canga Argüelles fueron abandonando sus hábitos artesanos, adoptaron las costumbres de los patricios de más alto empaque: el mismo don Felipe adquirió en el monasterio ovetense de San Francisco una sepultura en propiedad, al lado de los enterramientos de los marqueses de Valdecarzana, sobre cuya lápida colocó la aparente inscripción de su titularidad ${ }^{54}$. El

Argüelles viuda de don Gregorio Alvarez Blason, sus hijos don Ygnazio y don Francisco hijosdalgo»; feligresía de San Isidoro, calle de la Ferreria, f. 43: «Vizente Canga Argüelles hijodalgo. Santos Canga Argüelles que vive en Gijon y su hijo Nicolas hijodalgo». Ibídem, 4, Padrón de la ciudad de Oviedo del año 1787. Feligresía de San Tirso, calle de los Pozos, f. 81: «El señor don Phelipe Ygnacio Canga Argüelles, del Consejo de Su Majestad y su fiscal en la Real Audiencia de Zaragoza, sus hijos don Joseph y don Bernabe hixosdalgo»; calle del Rosal, f. 87: «Doña Josefa Canga Argüelles, viuda de don Gregorio Alvarez Blason viuda de hixodalgo, sus hijos el licenciado don Ygnacio presvitero fiscal eclesiástico de este obispado y Francisco hijosdalgo»; feligresía de San Isidoro, calle de la Ferreria, f. 112: «Don Vicente Canga Argüelles, hixodalgo. Don Santos Canga Argüelles su hermano que bive en Jixon y su hixo Nicolas, hijodalgo». AAO, B-48, 1, Padrón de la ciudad de Oviedo del año 1794. Feligresía de San Tirso, calle de los Pozos, f. 15: «El señor don Felipe Canga Argüelles del Consejo de su majestad en el Real y Supremo de Castilla, sus hijos don Josef y don Bernabe hijosdalgo». AAO, B-49, 1, Padrón de la ciudad de Oviedo y sus arrabales del año 1801. Feligresía de San Tirso, calle de los Pozos, f. 17 vto.: «El señor don Felipe Ygnacio Canga Argüelles cavallero pensionado de la orden de Carlos tercero del Consejo de Su Majestad el mas antiguo en el Supremo de Castilla, y sus hijos el señor don Josef del Consejo de Su Majestad su secretario, y oficial de numero de la secretaria de Hacienda, y don Bernave, hijosdalgo. El doctor don Felipe Vazquez Santullano abogado de los Reales Consejos y catedratico de Visperas en esta Universidad, hijodalgo. Doña Lazara Canga Argüelles viuda de don Benito Vazquez Santullano, viuda de hijodalgo, y su hijo el lizenciado don Bentura hijodalgo»; feligresía de San Isidoro, calle de la Escuela Vieja, f. 58: «Don Santos Canga Argüelles, y su hijo don Manuel capellan de Coro Viejo en la santa yglesia catedral de esta ciudad, hijodalgo». AAO, B-50, 1, Padrón de la ciudad de Oviedo del año 1815. Feligresía de San Tirso, calle de los Pozos, f. 17: «El doctor don Fhelipe Vazquez catedratico de prima de canones de esta Real Universidad hijodalgo»; f. 17 vto.: «Don Jose Canga Argüelles hijo del señor don Fhelipe del Consejo Supremo de Castilla difunto y sus hijos hijosdalgo»; feligresía de San Isidoro, calle de los Ángeles, f. 29: «Don Santos Canga Argüelles sus hijos don Manuel capitan de los Reales Exercitos, y doña Teresa, hijosdalgo». AAO, B-52, 1, Padrón de la ciudad de Oviedo del año 1831. Feligresía de San Tirso, calle de los Pozos, f. 16: «Señor don Jose Canga Argüelles ausente, y sus hijos don Jose y don Joaquin, hijosdalgo. Don Felipe Canga Argüelles, hijo del antecedente, y su hijo don Jose, hijosdalgo».

52 Domínguez Ortiz, Sociedad, pág. 353.

53 Así ocurre tanto en las pruebas de don Felipe, en 1797, como en las de su hijo don José, en 1805. Evidentemente para nadie era un misterio que la varonía de los Canga Argüelles no podía probar la limpieza de oficios, pero se pasó como sobre ascuas en lo que toca a este aspecto, que ya resultaba un auténtico anacronismo para la mentalidad ilustrada. Acaso no tanto para la sociedad, sobre todo cuando aquellos oficiales mecánicos se aprovecharon de la situación política para enriquecerse.

54 En las pruebas de don Felipe Ignacio se hace mención a ella. AHN, Estado, Carlos III, exp. 1032: Información y vista ocular en el monasterio de San Francisco de Oviedo, ff. 102 vto-103: «En seguida pasamos a la iglesia de San Francisco y en la sepultura que pega por el lado del evangelio con la inmediata a la del excelentisimo señor marques de Valdecarzana se halla la inscripción siguiente: Soy de el señor doctor don Phelipe Ygnacio Canga Argüelles de el Consejo de Su Majestad y su fiscal en la Real Audiencia de Zaragoza. 
convento era el lugar tradicional del sepelio de la nobleza más notoria del Principado y en su iglesia solían celebrarse con toda pompa las funciones funerales ${ }^{55}$.

Éste es el hogar en el que nació el que sería famoso hacendista. No se han puesto los autores de acuerdo ni en la fecha ni en el lugar de nacimiento de don José ${ }^{56}$. Fonseca Cuevas, sobre todo fijándose en la información de Huarte Jáuregui y en algunos testimonios fundamentales, de indiscutible crédito, se inclina por pensar que vio la primera luz en Oviedo, dentro de los límites parroquiales de San Tirso, el 11 de julio de $1771^{57}$. Ahora se añade a este dato, que es cierto, la inscripción bautismal. Había nacido en efecto el 11 de julio de 1771 y fue bautizado, no en la parroquia de San Tirso — que era la de la vecindad de los Canga Argüelles desde su venida a Oviedo ${ }^{58}$ — sino en la de San Isidoro, en el mismo día por el teniente de cura don Jacinto Antonio García. Se le impusieron los nombres de José Antonio Pío y fueron sus padrinos don José Antonio Canga Argüelles y doña María Francisca Fernández Mieres, sus abuelos paterno y materna ${ }^{59}$. El hecho de que el mismo día en que nació fuera acristianado asegura que su madre le dio a luz en la misma ciudad de Oviedo, pues parece muy poco probable que se expusiera a un recién nacido a un viaje desde fuera de ella. No se sabe por qué, siendo sus padres feligreses de San Tirso, y lo mismo su abuelo paterno el confitero José, sin embargo fue acristianado en la de San Isidoro. Lo más seguro es que viniera al mundo en el hogar de sus progenitores, que entonces debía estar en la calle de San Francisco, perteneciente a aquella parroquia ${ }^{60}$, pues en el acta bautismal de su hermana María Teresa, en 1783, de la que él fue padrino, se afirma que era

En el año de mil setecientos noventa y dos de el Supremo de Castilla», Oviedo, 20 de septiembre de 1797. Miguel Vigil recoge la inscripción de dos lápidas de la iglesia del monasterio de San Francisco de Oviedo. La que se encontraba en el centro del templo y al lado de la de los Miranda, marqueses de Valdecarzana, decía: «Soi de don Felipe Canga Argüelles caballero de la real orden de Carlos 3. ${ }^{\circ}$ del Consejo de Su Majestad en el Supremo de Castilla, y de sus hijos y subcesores». Había otra en la capilla mayor, que este historiador sólo alcanzó a ver en parte, por su deterioro, y lo que pudo descifrar era: «[...]lipe io[...] o $[\ldots]$ a $[\ldots]$ o $[\ldots]$ de su majestad [...] fiscal en $1[. .$.$] Audiencia d[...] Zaragoz[...]». Ciriaco Miguel Vigit, Asturias, monumental,$ epigráfica y diplomática. Texto, Oviedo, 1887, ed. facs. 1987, págs. 165 y 168; Láminas, Oviedo, 1887, ed. facs. 1987, láms. H VII y H XI.

55 Miguel Vigil, Asturias. Texto, págs. 157-180; Láminas, láms. H II-H XIV.

56 Fonseca Cuevas, Un hacendista, págs. 23-24.

57 Ibídem, pág. 24.

58 AHN, Estado, Carlos III, exp. 1032, ff. 12-14 vto.: Compulsa de los padrones de la ciudad de Oviedo en los que figuran los Canga Argüelles desde el año 1664 hasta el de 1794. Oviedo, 9 de septiembre de 1797.

59 Véase esta partida sacramental en el apéndice documental III de este trabajo.

60 María del Carmen Ansón Calvo, La ciudad de Oviedo en el siglo XVIII: estudio informático, Oviedo, 1990, págs. 203-204. 
natural de la colación de San Tirso ${ }^{61}$. Hay por lo tanto que concluir que vio la primera luz en esta feligresía.

Mientras vivió en Oviedo, Canga Argüelles debió de conocer a otro hidalgüelo que también estaba allí, estudiando en su universidad, y con el que tendría una estrecha $\operatorname{amistad}^{62}$. Con el paso del tiempo coincidirían en parecidas ideas políticas y económicas, y terminarían incluso por emparentar. Se llamaba don Felipe de Sierra Pambley y Fernández de Cuenllas ${ }^{63}$. Tenía los mismos humos nobiliarios que él, e igualmente procedía de atribuidos solares norteños, pero sus orígenes próximos no sobrepasaban un acomodo decente, fruto de la laboriosidad y el esfuerzo de sus mayores.

\section{Una presencia arqueológica: la colegiata de Arbas del Puerto}

A principios del siglo XIX pervivía encaramada sobre la cordillera entre Asturias y León, en la demarcación de este reino pero perteneciente a la dió-

61 Archivo de la parroquia de San Tirso El Real Oviedo (APSTO), Libro V de Bautismos de la parroquia de San Tirso El Real de Oviedo (1771-1804), f. 109 vto.: «[Al margen: Maria Teresa Canga. 313] En trece de octubre del año de mil setecientos ochenta y tres, don Francisco Menendez, mi escusador baptizo solemnemente en esta iglesia parroquial una niña, que nació el dicho dia, mes y año, y se llamo Maria Teresa Faustina hixa legitima del doctor don Phelipe Canga Argüelles natural de esta parroquia y de doña Paula Cifuentes natural de la villa de Jixon su muger y mis feligreses: fueron sus padrinos don Josef Canga Argüelles hermano de la niña natural de esta parroquia y doña Teresa Cifuentes tia de la niña y natural de la de Jixon; quedaron enterados de sus obligaciones, y del parentesco que la madrina no contruxo: en cuia fee lo firmo, como cura propio de esta parroquia [Firmado: Doctor don Sebastian Velez de Cossio]».

62 Francisco Carantoña Álvarez, «De la Ilustración al liberalismo moderado. La trayectoria política de Felipe Sierra Pambley», Ideas reformistas y reformadores en la España del siglo XIX. Los Sierra Pambley y su tiempo, Madrid, 2008, pág. 23.

Incluso un hermano de don Felipe, don Ángel, falleció en Oviedo en 1792. APSTO, Libro de Difuntos (1753-1798), f. 154: «[Al margen: Don Angel Sierra. 410] En siete de enero de mil setezientos noventa y dos murió en la parroquia de San Thyrso el Real de esta ciudad don Angel de Sierra Pambley natural de la parroquia de San Miguel de La Ceana, e hijo legitimo de don Angel Sierra y de doña Javiera Fernandez vecinos de dicha parroquia recibió los Santos Sacramentos de Eucharistia por Viatico y Extremaunzion, y se dio sepultura a su cadáver el dia siguiente con mi licencia en la iglesia de San Francisco de Oviedo, en cuya fe lo firmo como cura propio de la dicha de San Thirso [Firmado: Doctor don Sebastian Velez de Cossio]».

63 Cfr. AHN, Consejos, exp. 28: Expediente del bachiller don Felipe de Sierra Pambley y Fernández de Cuenllas sobre su recepción como abogado de los Reales Consejos (1798). Entre los documentos que existen en este legajo se encuentran: Certificación del licenciado don Manuel Cuvero, natural de Villanueva, jurisdicción de Ponferrada, vecino de Palacios del Sil y abogado de la Real Chancillería de Valladolid, en la que testifica que el bachiller don Felipe de Sierra Pambley asistió a su despacho desde septiembre de 1794 al mismo mes del año siguiente. Palacios del Sil, 30 de septiembre de 1795; Certificación del licenciado don Felipe Aldonza, vecino de León, abogado de los Reales Consejos, en la que testifica que el bachiller don Felipe de Sierra Pambley asistió a su despacho desde julio de 1795 hasta el día de la fecha. León, 27 de mayo de 1798; Certificación de don Pedro Mere, secretario de la Universidad de Oviedo, en la que testimonia que don Felipe de Sierra Pambley recibió en dicho establecimiento el grado de bachiller en leyes el 30 de junio de 1794. Oviedo, 8 de junio de 1798. 
cesis exenta de Oviedo, la real colegiata de Santa María de Arbas del Puerto de Pajares, bajo el patronato de la Corona ${ }^{64}$. La pervivencia de esta iglesia de orígenes medievales ${ }^{65}$ en aquellas alturas escasamente pobladas y con relativa utilidad sólo se debía a la inercia paralizante que embargaba no pocos aspectos del viejo orden ${ }^{66}$. Habían existido intentos de suprimirla o trasladarla a otros lugares más convenientes, con el fin de que sus prebendados cumplieran con mayor eficacia sus obligaciones religiosas y asistenciales, pero habían resultado fallidos ${ }^{67}$. Sus abades habían tenido frecuentes enfrentamientos jurisdiccionales con los obispos de Oviedo ${ }^{68}$ y la vida de los clérigos, en la segunda

64 AHN, Toledo, Nobleza, Osuna, 3867: Copia de privilegios reales concedidos a la colegiata y hospitales de Santa María de Arbas del Puerto. Vicente García Lobo, Santa María de Arbas. Proyección social y cultural de una canónica, León, 1987. Vicente y José Manuel García Lobo, Santa María de Arbas: catálogo de su archivo y apuntes para su historia, Madrid, 1980.

65 En la Baja Edad Media la colegiata de Santa María de Arbas era una de las cinco abadías regulares de la diócesis de Oviedo. Las otras eran Covadonga, Gurullés, Teverga y Celón. Por este tiempo su prelado ejercía el derecho de presentación íntegramente (Santa María de Casares, la capellanía de Santa María de la Pobla de Gordón, San Martino de Pobladura, San Miguel de Campongo, Santianes de Tonín, San Pedro de Ruydierno, San Pedro de Villanueva, Santo Andrés de Ventosilla, San Martino de la Puebla de Lena y San Miguel de Robredo, Santa María de Murias) y de forma compartida (San Miguel de Montosa y San Mames de Coviellas) en diversas piezas eclesiásticas. Se convirtió en abadía secular en 1419. Francisco Javier Fernández Conde, La Iglesia de Asturias en la Baja Edad Media. Estructuras económico-administrativas, Oviedo, 1987, págs. 24, 30, 125, 127-129, 133 y 134. García Lobo, Santa María de Arbas, págs. 44-50.

66 En 1565 la iglesia colegial de Arbas contaba con treinta prebendados, además del abad, tres dignidades (prior, tesorero y chantre), veinticuatro canonicatos y seis raciones. Había un sacristán y cuatro mozos de coro. Una parte considerable de los beneficiados no residían en ella. Según los estatutos de 1611 del abad don Francisco de Neira y Turienzo, las piezas eclesiásticas eran la abadía, el priorato, la tesorería, la chantría, nueve canonicatos y ocho raciones. En 1630 la abadía tenía una renta de 1000 ducados y cada uno de sus doce canónigos disponía de 80. En 1639 los cálculos eran ligeramente distintos: el prelado de Arbas poseía unos ingresos como tal valorados en 800 ducados y los restantes prebendados, en número de veinte, 70. Según la concordia de 1645 entre el obispo de Oviedo don Bernardo Caballero de Paredes y el prelado de la colegial don Suero Queipo de Llano, el personal eclesiástico debía componerse de un abad, las tres dignidades señaladas ya en otras ocasiones, ocho canónigos y cuatro racioneros, en los que se incluirían aquéllas. En 1725 el abad de Arbas disponía de 2500 ducados. En este año, además del prelado, había en esta iglesia doce prebendados, de los que tres eran el prior, el chantre y el tesorero. A mediados del siglo XVIII el cabildo estaba compuesto por el abad, el prior, el tesorero y siete u ocho canónigos; al menos, éstos eran los residentes. Según los estatutos de 1797 los canónigos no debían pasar de doce. García Loвo, Santa María de Arbas, págs. 51-52, 64, 74 y 79. José Luis GonzÁlez Novalín, Las visitas «ad limina» de los obispos de Oviedo (1585-1901). Una fuente eclesiástica para la historia de Asturias, Oviedo, 1986, págs. 81, 123 y 149.

67 Existió un intento de trasladarla a Mayorga de Campos, auspiciada por el señor de esta villa, el conde de Benavente, por los años 1565-1566. AHN, Toledo, Nobleza, Osuna, 486: Información sobre el proyecto de trasladar la colegiata de Santa María de Arbas del Puerto a la villa de Mayorga de Campos (1565). García Lobo, Santa María de Arbas, págs. 58-59.

68 García Lobo y Tuñón Escalada recogen los conflictos y arreglos que existieron entre el obispo de Oviedo y el clero colegial por los años de 1419, 1610, 1628-1645, 1662 y 1772-1793. García Lobo, Santa María de Arbas, págs. 68-69. Juan José Tuñón Escalada, Don Agustín González Pisador, obispo de Oviedo (1760-1791). Iglesia y sociedad en Asturias, Oviedo, 2000, págs. 180-206. GonZÁlez Novalín, Las visitas, págs. 81, 123 y 149. 
mitad del siglo XVIII, solía ser bastante asilvestrada, cuando no francamente disoluta ${ }^{69}$.

Dependientes de la iglesia, de antigua y bella arquitectura, se encontraban dos hospitales con el deber de atender los viajeros y peregrinos que por aquel puerto transitaban ${ }^{70}$.

En el siglo de las luces, pocos eran los que comprendían la existencia de aquella reliquia del pasado. Sus provechos aparecían ningunos, sobre todo en un tiempo en el que el utilitarismo materialista quería incluso imponerse a los aspectos más espirituales de la realidad eclesiástica. Sin embargo, no debía ser este criterio muy parcial cuando los propios ordinarios, así un obispo tan tradicional como don Gregorio Ceruelo de la Fuente, se mostrarían conformes en aniquilar la institución ${ }^{71}$. El prelado de Oviedo don Agustín González Pisador, encargado por la Corona de establecer un plan de dotación de las cátedras universitarias, puso sus ojos en las rentas de la colegiata. A mediados de la década de los setenta del siglo XVIII el prelado propone a la Corte suprimir la iglesia, trasladar sus obligaciones asistenciales al Hospital General, que se pensaba erigir, incorporar las cargas piadosas en la capilla de la universidad, emplear a los prebendados en otros beneficios de la diócesis, racionalizar la cura de almas de los pueblos inmediatos a la iglesia y, naturalmente, con el sobrante de rentas, subsidiar la reforma académica ${ }^{72}$.

Tuvo el obispo en la corte el apoyo incondicional del fiscal del Consejo de Castilla, don Pedro Rodríguez de Campomanes, pero fueron pasando los años y nada terminó por decidirse ${ }^{73}$. Ya durante el reinado de Carlos IV el nuevo obispo de Oviedo, don Juan de Llano Ponte, vuelve a elevar a la corte la propuesta de supresión, pero tampoco en este caso tuvo éxito; es más, la Cámara de Castilla, lejos de favorecer el proyecto, contesta en 1796 que no es suficiente causa la dotación universitaria para extinguir la colegiata a la que califica de «monumento tan recomendable y antiguo ${ }^{74}$ ». Se ve que las ambiciosas ínfulas del reformismo carlostercista se habían suavizado, efecto

69 En 1767 una real cédula de Carlos III, como patrono, impone un conjunto de preceptos disciplinares que indican la flojedad moral de los prebendados. En 1781 el obispo ovetense don Agustín González Pisador se queja al Consejo de Castilla de la laxitud del clero colegial, cuyos miembros abusan del alcohol, son pendencieros e incumplen sus obligaciones canónicas. En la visita que en 1787 hace a la colegiata por comisión regia el chantre de la catedral de Oviedo, don Jacinto Díaz de Miranda, se promueve el proceso del chantre don José de Robles Castañón y de su hermano don Juan, entonces vicario capitular, sede vacante. García Lobo, Santa María de Arbas, págs. 74-77. Tuñón Escalada, Don Agustín, págs. 201-204.

70 García Lobo, Santa María de Arbas, pág. 82.

71 Tuñón Escalada, Don Agustín, págs. 206-207.

72 Ibídem, págs. 197-198.

73 Ibídem, págs. 198-199.

74 Ibídem, págs. 199-200 y 205-206. 


\section{sin duda de las expresivas lecciones de la Revolución francesa ${ }^{75}$. La verdad es que contra viento y marea y en medio de frecuentes percances Arbas pervivió hasta bien entrado el siglo XIX ${ }^{76}$. Fue necesario el terrible colapso que padeció la Iglesia a raíz de la implantación del sistema liberal ${ }^{77}$, y como efecto de la}

75 HERr, España, págs. 197-260.

76 En 1847 los vecinos de la parroquia de Pola de Lena apoderan a don Manuel Álvarez Buylla y a don Francisco Díaz, de la misma residencia, para que hagan las diligencias precisas del traslado de la colegiata a la referida feligresía. Archivo Histórico de Asturias (AHA), Oviedo, Protocolos de Lena (PL), 10 538, Protocolo del año 1847 del escribano Pedro Antonio de Aza Muñiz, f. 31-31 vto., Pola de Lena, 2 de febrero de 1847: «Don Francisco del Fueyo alcalde pedaneo de la parroquia de esta capital con don Antonio Hebia Campomanes vecino de ella, don Antonio Tuñon que lo es del valle de Palacios de la misma, don Gregorio Gonzalez y don Francisco Fernandez de Cabo del Valle de Muñon de la repetida parroquia con don Jose Tuñon que lo es del valle espresado el que hizo de la misma y asi juntos en representación de los demás vecinos de la membrada parroquia de la Pola de quienes están facultados in voce según constumbre dijeron: que ya antes de ahora se ha intentado el que fuese trasladada la colegiata de Santa Maria de Arbas del Puerto a esta capital por ser mas útil en ella que el paraje montañoso que ocupa a la continua cubierto de nieve esponiendo las poderosas razones para la referida traslación que asistia a los reclamantes lo otro y ventajoso que se reportaba en ello, pero parece que se han retardado las providencias para conseguirlo y siendo ahora mas que nunca la utilidad que se sigue en que se fije en la yglesia parroquial de esta capital aquel piadoso establecimiento por la presente en la mejor forma que pueden y en derecho lugar haya por si y en representación de los demás vecinos de la repetida parroquia otorgan que dan todo su poder cumplido cual por derecho se requiere y es necesario a don Manuel Alvarez Buylla y a don Francisco Diaz, vecinos también de esta villa y capital, para que a nombre de los otorgantes y demás vecinos soliciten y espongan las razones que hallen oportunas para que se consiga el remover la citada colegiata a la yglesia de esta capital haciéndolo presente al ylustre ayuntamiento del concejo y elevándolo a donde competa y corresponda y hasta conseguirlo hagan y practiquen cuantas solicitudes y agencias sean necesarias pues que el poder que para conseguirlo es necesario ese mismo dan a los Buylla y Diaz».

77 La situación económica de los prebendados de Arbas en el siglo XIX nos la testimonia este documento, procedente del archivo de la casa de Carvallo, de los Flórez de Valdés, linaje al que pertenecía el abad don Manuel Flórez de Valdés:

Archivo de la casa de Carvallo, Cangas del Narcea, sin catalogar: «Numero 1. ${ }^{\circ}$ : Colegiata de Arbas del Puerto. Nomina de los individuos que componen el clero de esta colegiata con espresion $1 .^{\circ}$ de la renta anterior que han acreditado que antes correspondió a sus respectivas prevendas en el año común del quinquenio de 1829 al $33 ; 2 .^{\circ}$ de la dotación que actualmente les corresponde con arreglo a la ley; $3 .^{\circ}$ de lo que perciben en cuenta de esta misma dotación por razón del levantamiento de las cargas de obras pias y fundaciones particulares de aniversarios, misas y otras funciones o festividades religiosas; $4 .^{\circ}$ del haber liquido que debe avonarseles por el Tesoro; 5. ${ }^{\circ}$ de lo percivido a buena cuenta en virtud de las ordenes para el pago del tercio, y $6 .^{\circ}$ de lo que les falta percivir para su completo.

Abad don Manuel Florez Valdes: 1. ${ }^{\circ}$ Renta anterior 24887 (reales) 14 (maravedís); 2. ${ }^{\circ}$ Dotacion actual 12000 (reales); $3 .^{\circ}$ Percepcion en cuenta; $4 .^{\circ}$ Haber liquido 12000 (reales); 5. ${ }^{\circ}$ Percivido a cuenta; $6 .^{\circ}$ Falta para su completo 12000 (reales).

Dignidades. Don Domingo Vega, dignidad de tesorero: $1 .^{\circ}$ Renta anterior 5251 (reales) 20 (maravedís); 2. ${ }^{\circ}$ Dotacion actual 5251 (reales) 20 (maravedís); 3. ${ }^{\circ}$ Percepción en cuenta; 4. ${ }^{\circ}$ Haber liquido 5251 (reales) 20 (maravedís); 5. ${ }^{\circ}$ Percivido a cuenta; $6 .^{\circ}$ Falta para su completo 5251 (reales) 20 (maravedís). Don Francisco Abol, chantre: $1 .^{\circ}$ Renta anterior 5251 (reales) 20 (maravedís); 2. ${ }^{\circ}$ Dotacion actual 4900 (reales); $3 .^{\circ}$ Percepcion en cuenta; $4 .^{\circ}$ Haber liquido 4900 (reales); . $^{\circ}$ Percivido a cuenta; $6 .^{\circ}$ Falta para su completo 4900 (reales).

Canonigos. Don Francisco Simon Roces, viceprior: 1. ${ }^{\circ}$ Renta anterior 5251 (reales) 20 (maravedís); 2..$^{\circ}$ Dotacion actual 4900 (reales); 3. ${ }^{\circ}$ Percepcion en cuenta; $4 .^{\circ}$ Haber liquido 4900 (reales); 5..$^{\circ}$ Percivido a cuenta; $6 .^{\circ}$ Falta para su completo 4900 (reales). Don Carlos Ramirez de Arellano, ausente. 
firma del sanador concordato de 1851, para que al fin la venerable institución fuera cancelada definitivamente ${ }^{78}$.

Por las respuestas generales del catastro de Ensenada, en el año 1753, se conoce el desamparado paraje en el que estaba situada la colegial. Se trataba de un término realengo de cortas dimensiones, con exigua población y algo peculiar, pues la justicia la ejercía, por no haber vecino lego, el propio abad. Por entonces las piezas eclesiásticas eran la abadía, el priorato, la tesorería, la chantría y nueve canonicatos, aquélla de nominación soberana y las restantes de nombramiento del prelado de Arbas y refrendo real. Los habitantes de la villa eran los prebendados, sus dependientes y el que asistía al hospital. Económicamente era un típico territorio de alta montaña, dedicado a la ganadería, sin árboles frutales, con algunos prados y, sobre todo, bosques y pastizales, en los que residía su principal valor material. Estos se arrendaban a ganados forasteros como los del monasterio jerónimo de Santa María de Guadalupe, en Extremadura, o los de los duques de Alburquerque. Con tales ingresos se mantenía el culto y clero colegial. El caserío resultaba mínimo, se reducía a trece casas. Lo más relevante era, por lo tanto, la propia fábrica de la colegiata. No existía ninguna clase de industria ni actividad artesanal, salvo la que revela la existencia en el término de tres molinos harineros, dos de ellos propiedad del hospital ${ }^{79}$.

De la titularidad de los establecimientos benéficos dependientes de Arbas era el coto de Lindes, una pequeña demarcación señorial situada en el extremo meridional del municipio realengo de Quirós ${ }^{80}$. Una vez más hay que recurrir al catastro de Ensenada para conocer con detalle las características de esta jurisdicción. De sus respuestas se deduce que Lindes no era una gran cosa, pero lo suficiente para que fuera considerado una alhaja estimable por los abades y canónigos de la colegiata, auténticos y efectivos señores del coto, como administradores de sus hospitales ${ }^{81}$.

Nota. Si bien don Francisco Simon Roces como canónigo no gozaba mas que una renta de 4751 reales 20 maravedis, según el año común del quinquenio de 1829 a 1833 [tachadura] por la cualidad de viceprior [tachadura] recibia el aumento de 500 reales annuales [tachadura] asignados por el servicio que exerce de la cura de almas durante la vacante de la dignidad prioral, y por consiguiente escede el todo de su renta a la dotación de la ley, razón por que al respecto de ella se le pone en la nomina».

78 García Lobo, Santa María de Arbas, págs. 84-85. González Novalín, Las visitas, pág. 190.

79 Véase apéndice documental II. Cfr. García Lobo, Santa María de Arbas, págs. 169-173: Informe del visitador don Jacinto Díaz de Miranda, chantre de la catedral de Oviedo, Madrid, 27 de octubre de 1789.

80 Ya consta cómo en la Alta Edad Media este territorio de Lindes pertenecía a la iglesia de Santa María de Arbas. Aparece en un diploma del rey Alfonso IX de León a favor de esta institución y sus hospitales. AHN, Consejos, 11546, núm. 682: Instancia de don Pedro de Miranda Ronzón, cura párroco de Santa María de Bermiego (Quirós), en nombre de su pupilo don Diego de Miranda Ronzón, sobre la incorporación del coto de Lindes (siglo XVIII).

81 García Lobo, Santa María de Arbas, pág. 79. 
Su población en 1752 no alcanzaba más allá de siete vecinos ${ }^{22}$, para los que existía una parroquia, bajo la advocación de Santo Tomás, cuya erección se había debido a la munificencia de los Miranda en el siglo Xvi ${ }^{83}$. La mayor parte del terreno era inculto y sin utilidad, por su quebrada geografía. Había poca horticultura y predominaban las praderías y los pastizales. Los términos susceptibles de pasto se arrendaban a los jerónimos de San Lorenzo de El Escorial, y con este ingreso se mantenían los hospitales de Arbas. Por razón del señorío pagaba cada vecino un cordero al año, pero ninguno de los habitantes estaba sujeto a otra fiscalidad o tributo, salvo el de naturaleza canónica ${ }^{84}$.

En 1581 el cabildo colegial había aforado el coto a la familia más ilustre de la comarca, y en quien confiaba la recta administración de sus rentas ${ }^{85}$. Se trataba de una de las ramas de la casa de Quirós, aunque utilizara por apellidos comunes los de Miranda Ponce de León ${ }^{86}$. Por esta razón, el linaje

82 La población del coto siempre fue muy corta. Si a mediados del siglo XVIII tenía siete vecinos, en 1688 poseía los mismos hogares. AHN, OM, Santiago (S), 5345, Pruebas de don Rodrigo de Miranda y Quiñones, alcalde de Casa y Corte (años 1687-1688), f. 85, Lindes, 13 de febrero de 1688: «El mesmo dia, por no aver en la cortedad del lugar (que no pasa de siete vecinos) [...]».

83 AHN, OM, S, 5345, f. 85-85 vto, Diligencia en la iglesia parroquial de Santo Tomás de Lindes, Lindes, 13 de febrero de 1688: «[Al margen: Parrochia de Lindes] Luego incontinenti pasamos a las casas de morada del lizenciado don Juan de Miranda cura propio de la parroquia de Santo Thomas deste lugar de Lindes, y le requerimos nos exibiesse los libros de bautiçados, casados y difuntos que parasen en su poder, aviendole hecho nos manifestó uno de quartilla con cubierta de pergamino en que están asentados los bautiçados, confirmados, casados y difuntos que se començo a escribir el año de seiscientos y setenta, y en el están puestos algunos asientos de bautiçados que andaban en ojas sueltas por mandado del visitador, y en el por ser tan moderno no hallamos la fee de bautismo de don Rodrigo de Miranda abuelo materno del pretendiente, y pidiendo al dicho cura los libros antiguos, juro in verbo sacerdotis, que aunque ha algunos veynte y quatro años que es cura de dicha parroquia, no hallo en ella libro alguno, no sabe a donde puedan parar. Y en un misal que tiene dicha parroquia, en la parte interior de la tabla del se halla una certificación de Melchor Alvarez de Cienfuegos de cómo lunes veynte y uno de agosto octavario de la Asumpcion de Nuestra Señora año de mil quinientos y ochenta y quatro se dixeron las primeras misas en la iglesia de Santo Thomas de Lindes en que dice se hallaron presentes los ylustres señores Martin de Miranda y doña María del Busto Ribera su muger fundadores de la dicha iglesia, y para que conste lo firmamos junto con el dicho cura que se hallo presente [al margen: Los rebisabuelos maternos fundadores de la parrochia de Lindes] [Firmado: Alonso Antonio de Heredia] [Firmado: Toribio Zienfuegos] [Firmado: Juan de Miranda Quiros y Salas]».

84 Véase apéndice documental I.

85 En 1581 el cabildo colegial de Arbas aforó el coto a Martín de Miranda, vecino de Llanuces (Quirós), por 12000 maravedíes al año y una vaca y ternero de entrada. Vicente José González García, La casa de Quirós: historia del concejo de Quiros, Oviedo, 1958, pág. 189. AHN, Consejos, leg. 11546, núm. 682: Instancia: «[...] una ynformazion hecha de orden del referido gobernador de Obiedo ante Bartholome Albarez Manzano juez hordinario en 15 de henero deste año de 1708 de que resulto que la jurisdicción del coto de Lindes, la poseía el rreferido Diego de Miranda Ronzon, i sus antezesores de tiempo inmemorial por foro perpetuo que habían fundado, a favor del expresado hospital de Arbas pagándole cada año 120 maravedis y que los bezinos de esta jurisdicción no pagaban cantidad alguna por razón de vasallaje, sino es que siempre se llevaban renta la hazienda como en las demas partes realengas».

86 Numerosos datos sobre esta familia de los Miranda, señores, o mejor dicho, foreros del coto de Lindes, se pueden ver en el expediente para ingreso en la orden de Santiago de don Rodrigo de Miranda y Quiñones, alcalde de Casa y Corte, citado en la nota 81. Su madre doña María de Miranda era hija de don 


\section{en los siglos XVII y XVIII se titulaba con el señorío de Lindes, como dueños del dominio útil ${ }^{87}$, coto que incorporó a sus mayorazgos ${ }^{88}$. Pero en 1737 , y}

Rodrigo de Miranda Ponce, señor de Lindes, y de su mujer doña Leonor Morán de Rivera. El 28 de octubre de 1700 fue agraciado con el título de conde de San Pedro, con facultad de designar sucesor, pues no tenía hijos. AHN, Consejos, 8975, A. 1700, exp. 138: Real despacho de concesión de la merced de conde de San Pedro, con facultad de nombrar sucesor por no tener hijos, a don Rodrigo de Miranda y Quiñones, previa la cancelación del título previo de vizconde de Añe, 28 de octubre de 1700. Cfr. Luis de Navia-Osorio y Castropol, Datos para la historia del concejo de Navia, I, Oviedo, 1981, págs. 305, 308 y 310.

87 AHN, OM, S, 5345, ff. 30-32 vto.: Diligencia de los padrones del concejo de Quirós, Bermiego (Quirós), 1 de febrero de 1688. Padrón del concejo de Quirós del año 1644, sexma de Muriellos y Coañana: «Rodrigo de Miranda señor del coto de Lindes hijodalgo notorio de casas y solares conocidos de armas poner y pintar descendiente de las casas de Quiros y Miranda». AHA, PL, 10372: Protocolo del año 1691. Escribano Juan García Campomanes, ff. 144-145 vto.: Testamento de don Gabriel de Miranda, vecino de las Casas de Ronzón (Lena) y señor de Lindes. Casas de Ronzón, 5 de octubre de 1691, f. 144: «Don Gabriel de Miranda señor del coto y jurisdizion de Lindes y vecino de las casas deste concejo de Lena». AHN, Consejos, leg. 11546, núm. 682: Instancia: «Dice que se alla siendo tutor y curador de la persona y vienes de don Diego de Miranda Ronzon vecino del concejo de Elena señor del coto y jurisdizion de Lindes». AHA, PL, 10375: Protocolos de los años 1699-1700. Escribano Juan García Campomanes, f. 99: Licencia otorgada por don Fernando de Miranda Ronzón, regidor perpetuo de Lena y señor de la casa de Ronzón y del coto de Lindes a su cuñado don Miguel González de Lena, vecino del Peridiello (Lena) y a sus caseros, Pedro Fernández, Toribio García Barroso, Martín de la Rua y Antonio de la Rua, para que los ganados de aquel puedan pastar en los montes y puertos de Lindes por espacio de cuatro años por renta de 50 reales anuales. Torre y Casas de Ronzón, 29 de mayo de 1700: «Don Fernando de Miranda Ronzon regidor perpetuo de este concejo señor de estas casas y del coto y jurisdizion de Lindes»; f. 100-100 vto.: Licencia otorgada por don Fernando de Miranda Ronzón, regidor perpetuo de Lena y señor de la casa de Ronzón y del coto de Lindes a Domingo Suarez, vecino de Cornellana, a su criado Domingo de Llanes, Diego Bernaldo, vecino de Cornellana, Domingo la Fuente, de Tíos, Juan Fidalgo, de Palacio, Juan Fernández, de Palacio, su yerno, y Juan Alonso de las Campas, todos vecinos del concejo de Lena, para que puedan cortar leña y madera y sus ganados pastar en los términos de Lindes, por tiempo de cuatro años, a razón de setenta y seis reales anuales. Torre y Casas de Ronzón, 29 de mayo de 1700, f. 100: «Don Fernando de Miranda Ronzon señor de esta dicha casa y del coto y jurisdizion de Lindes regidor perpetuo de este dicho concejo». AHA, PL, 10376: Protocolos de los años 1703-1704. Escribano Juan García Campomanes, ff. 48-49 vto.: Escritura otorgada por don Fernando de Miranda Ronzón, señor de la casa de Ronzón y del coto de Lindes, y regidor perpetuo del concejo de Lena, en nombre de la Justicia y Regimiento de este municipio, en la que arrienda al real monasterio de San Lorenzo de El Escorial, representado por José Casillas, vecino de la villa de Aldeavieja, jurisdicción de la ciudad de Segovia, los puertos y majadas de Vallalampayos y Carbajal, sitos en La Vallota, en el concejo de Lena, y las cuestas y colgadas de Retuerto y Acebos, por espacio de nueve años, y renta de 4400 reales cada uno de ellos. Casa de Ronzón (Lena), 4 de septiembre de 1704, f. 48: «Don Fernando de Miranda Ronçon señor de estas casas y del coto de Lindes, y regidor perpetuo de este concejo».

88 AHA, PL, 10372: Protocolo del año 1691. Escribano Juan García Campomanes, ff. 144-145 vto.: Testamento de don Gabriel de Miranda, vecino de las Casas de Ronzón y señor de Lindes. Casas de Ronzón, 5 de octubre de 1691, f. 145-145 vto.: «Ytem digo que yo hize y otorgue una escriptura matrimonial para casarse dicho don Fernando mi sobrino con la dicha doña María Francisca por testimonio de Francisco Alvarez Vazquez escribano del numero deste concejo de Lena la qual apruebo y ratefico de la manera que en ella se contiene y della constara aber yo vinculado en fabor del dicho mi sobrino y de dicho matrimonio cantidad de vienes raizes [...]. Bolvio a añadir que la dicha mejora que hice a fabor de dicho mi ssobrino fue del coto dicho de Lindes con todo lo a el anejo y otros vienes a cuya mejora agrego ahora el mi castañedo de la Cueba del Gato sito en términos del lugar de Villar de Çienfuegos del dicho coto de Quiros para que con el dicho coto de Lindes vaya de mayor en mayor y no se pueda vender ni enajenar y en casso que dicho coto salga de poder de dicho don Fernando mi sobrino y mas sus descendientes o de don Diego de Miranda difunto mi hermano en tal casso no vaya con dicho coto dicho castañedo». 
merced a la política incorporacionista de la Corona, los Miranda lo perdieron al reintegrarse la plenitud de los derechos en la colegiata y sus instituciones hospitalarias ${ }^{89}$. El quebranto debió ser dolorosísimo para la estirpe, y así en 1780 lo recordaba don Fernando de Miranda: «[...] que todo el mayoradgo principal de su baronia que hera la casa y coto de Lindes lo perdió em pleito letigado y contencioso en el supremo consejo de la cámara donde le gano el real hospital de Arbas» ${ }^{90}$.

Es indudable que el gran valor de este territorio no era la jurisdicción, sino los derechos solariegos y de pastos y montes, los cuales, todos en globo, con el patronato de la parroquial, en el año 1700, se habían tasado en 8000 ducados:

El lugar de Lindes con sus casas horrios, tierras, y prados y molinos iglesia parroquial, montes, puertos, coto, y jurisdiçion civil y criminal, pastos, y derechos de que ninguna otra persona en dichos montes y puertos puede entrar e pastar ganados ni cortar leña, ni madera alguna ni sacarla y el que lo haze es prendado y penado en seiscientos maravedís por cada prenda como esta definido por rreales sentencias y cartas executorias, linda con este concejo de Lena, y con el de Quiros y esta amoxonado y bien conozido y el patronato ynsolidum y en todo tiempo de la dicha yglesia y de su curato tasase en ocho mil ducados ${ }^{91}$.

Por un pleito de hidalguía en la chancillería de Valladolid litigado en los años de 1794 y 1795 por los hermanos Fernando, Francisco y José Arias, vecinos del coto de Lindes ${ }^{92}$, conocemos cuál era la situación de esta jurisdicción a finales del siglo XVIII. El escribano del Ayuntamiento de Quirós Francisco Álvarez Cienfuegos certifica:

Como en el coto de Lindes incluso en este concexo de Quiros jamás se formaron padrones a calleita entre hidalgos y pecheros, no hay en el archivo no se executan listas de repartimientos contribuciones alojamientos, ni bagajes de que se hallan esentos los vecinos de dicho coto por hallarse tenidos y reputados en el

89 González García, La casa, pág. 189.

90 AHA, PL, 10426: Protocolo del año 1780, s. fol., Pola de Lena, 14 de octubre de 1780: Escritura de poder otorgada por don Fernando de Miranda Ponce de León, señor de la casa y torre de Ronzón y regidor perpetuo del concejo de Lena, a favor de Agustín García Gutiérrez, procurador del número de la Audiencia de Asturias para que le represente en la causa que contra él sigue su hijo natural don Francisco de Miranda Ponce, vecino del coto de Olloniego, al reclamarle alimentos por decir que era inmediato sucesor de sus mayorazgos.

91 Ibídem, 10375: Protocolo de los años 1699-1700, s. fol.: Partición de los bienes de don Diego de Miranda Valdés y de su esposa doña Mayor Álvarez de Ronzón, señores de la casa de Ronzón y del coto de Lindes. Vega del Ciego (Lena), 22 de mayo de 1700-Pola de Lena, 12 de junio de 1700.

92 Archivo de la Real Chancillería de Valladolid (ARCHV), Sala de Hijosdalgo (SH), 1005-26. 
concepto de nobles i asimismo certifico como los vecinos del indicado coto handan unidos con los de este concexo para el anual reemplazo de las milicias urbanas de este principado, lo mismo para los sorteos estraordinarios que ocurren y quintas que acaecen ${ }^{93}$.

\section{Y el nombramiento del único juez que existía para tan corto vecindario era competencia de la colegiata:}

En el coto de Lindes incluso en este concexo de Quiros pone un juez noble la real colegiata de Santa Maria de Arbas del Puerto, cuio empleo ya años lo exerce don Pedro Antonio de Haza vecino de la villa de la Pola capital del consejo de Lena, quien por carta o recado, sin otro requisito pone teniente, que en dicho coto no se celebran elecciones de oficios de xusticia, no hay en el regidores, procuradores de uno ni otro estado, personero del común, diputados ni otro miembro de xusticia, tampoco hay escribano, ni fiel de fechos ${ }^{94}$.

Por ser el abad y cabildo de Arbas, como gestores de sus hospitales, grandes propietarios en el término y su única e inmediata autoridad administrativa, no es extraño que los testigos afirmen que los individuos de la colegiata eran los

93 Ibídem, f. 16-16 vto.: Certificación de Francisco Álvarez Cienfuegos, escribano de número y ayuntamiento del concejo de Quirós, Bárzana (Quirós), 24 de octubre de 1795. En el concejo de Quirós, con el que el coto de Lindes andaba unido para ciertos efectos a finales del XVII, el estamento nobiliario era unánime. AHA, PL, 10375: Protocolos de los años 1699-1700. Escribano Juan García Campomanes, f. 101-101 vto.: Poder otorgado por don Martín de Miranda Quirós y Ponce, señor de la casa de Llanuces (Quirós), y don Fernando de Miranda Ronzón, señor de la casa de Ronzón y del coto de Lindes a favor de don Rodrigo de Miranda, conde de San Pedro, del Consejo de Castilla, para que los represente en la petición sobre que se cumpla lo ya proveído en la elección de las justicias del concejo de Quirós. Ronzón, 29 de mayo de 1700, f. 101: «Por quanto a instancia de la justiçia y rreximiento del dicho concejo de Quiros se ocurrió al rreal consexo y se hiço rrelaçion çierta que el dicho concejo se conponia de veinte lugares en que avia mas de ochoçientos vecinos y siempre se avia gobernado por dos alcaldes o jueçes hordinarios con ygual jurisdiçion uno del estado noble y otro del estado llano y que al presente se avian estinguido muerto y ausentado todos los vecinos pecheros de dicho estado llano de calidad que no se allaba ningún vecino deste estado en el dicho concejo hábil para el uso y exerçiçio de su vara de tal alcalde hordinario y que solo se nombraba el alcalde del estado noble en que se avia experimentado carecer el dicho concejo de administraçion de justicia por ser dilatado de casi quatro leguas y diferentes valles muy distantes dichos lugares y no poder dicho alcalde solo acudir con la pronptitud que se necesitaba a la administración de justiçia y execuçion y cunplimiento della concluiendo con pedir y suplicar se mandase despachar rreal provisión para que en el interin que en dicho concejo avia vecinos vastantes del estado llano que pudiesen servir la dicha vara se eliguiese en la forma hordinaria y con efecto se libro y despacho justamente dicha rreal provisión para que por ahora y sin perjuicio del derecho de dicho estado llano para quando le hubiese en dicho concejo se nonbrase en el dos alcaldes del estado de hixos de algo con igual jurisdiçion como mexor y mas largo constara de dicha rreal provisión de diez de marzo deste presente año».

94 Ibídem, f. 15 vto.: Informe de Francisco Álvarez Cienfuegos, escribano de número y ayuntamiento del concejo de Quirós, Bárzana (Quirós), 24 de octubre de 1795. 
dueños despóticos del coto y jurisdicción ${ }^{95}$. Así pues, en esta manera, llegó el diminuto enclave señorial a principios del siglo XIX, cuando un caballero ilustrado, dispuesto a ser un patricio de los de alto coturno, como eran los grandes próceres de la aristocracia, se convirtió en señor despótico de Lindes.

\section{Un asunto de familia}

Como se ha visto, en los tiempos ilustrados, ni la colegiata de Arbas, ni sus hospitales, ni la titularidad señorial sobre Lindes eran realidades dignas de conservar. Para la Corona, la dignidad abacial bajo su derecho de presentación suponía una única ventaja. Como era un beneficio dotado con cierta opulencia su provisión representaba una forma de premiar servicios o atender compromisos sociales y cortesanos ${ }^{96}$. El disfrute de la pieza, apetecida por sus emolumentos, tenía el inconveniente del lugar de su ubicación ${ }^{97}$.

95 Ibídem, ff. 20 vto.-23: Testimonio de Gaspar Fernández, vecino del coto de Lindes, Bárzana (Quirós), 10 de julio de 1794, f. 22: «El cabildo y colexiata de Arvas de el Puerto, como dueño espotico de dicho coto y jurisdizion»; ff. 23-24 vto: Testimonio de Francisco Campomanes, vecino del coto de Lindes, Barzana, 10 de julio de 1794, f. 24: «Abadia de Arbas y sus individuos, como dueños espoticos de dicho coto».

96 Al morir don Ignacio Álvarez Brasón, al que nos vamos a referir a continuación, debió de ser nombrado abad de Arbas don Antonio Cidrón y Bernal. A éste, García Lobo lo hace ya prelado en 1828. AHA, PL, 10530: Protocolo del año 1829. Escribano Pedro Antonio de Aza Muñiz, f. 63-63 vto.: Escritura de poder otorgada por don Antonio Cidrón y Bernal, abad, don Domingo Antonio de la Robla y Redonda, don José Suarez Quirós, chantre, don Juan García Campomanes, don Francisco de Abol, don Domingo de Vega y don Pedro de Vega, canónigos, todos prebendados de la colegiata de Nuestra Señora de Arbas del Puerto de Pajares, a favor de don Gregorio Menéndez, también prebendado de la misma iglesia. Campomanes (Lena, Asturias), 24 de febrero de 1829. A Cidrón y Bernal se refiere don José Arias Teijeiro en sus interesantes diarios: Documentos del reinado de Fernando VII, III, Arias Teijeiro. Diarios (1828-1831), I, Pamplona, 1966, pág. 158 (18 de junio de 1829): «Calvo [oficial de los Voluntarios Realistas], que habla por boca del hijo de su vecino Echauru [don Luis García de Pando Echaburu, tesorero de la Colecturía General de Expolios y Vacantes], tesorero de espolios [cuyo realismo afectado conocemos], me alabó mucho al abad de Arvas, que está en casa de aquél: que va y viene al Sitio, y que lo harán consejero de Órdenes. No pude impedirme de defender con calor al obispo de Oviedo [el absolutista don Gregorio Ceruelo de la Fuente, que se enfrentó con Calomarde por causa de la presentación regia de Sánchez Caro o Caso, un clérigo comprador de bienes desamortizados, para un arcedianato en la diócesis de Oviedo al que el prelado por irregularidad canónica negaba la posesión] públicamente, y de hacer callar con la verdad a Calvo. No hay duda que tiene favor en el Sitio, que ha estado mucho con Calomarde, etc. (V. D. Juan). Un recomendado del deán Barreiro [don Juan Antonio Barreiro, deán de la catedral de Oviedo] dijo también a N que el Abad era un santo, etc. Sí, el sabe engañar, pero ¡tales son los engañados!». Archivo Capitular de Oviedo, Pruebas: Genealogía y Limpieza de Sangre, tomo IV, exp. 5: Pruebas de limpieza de sangre de don Juan Antonio Barreiro y Alfonso Rodríguez Valledor, nombrado deán de la catedral de Oviedo (1828). Vicente CÁRcEL OrTi, Correspondencia diplomática del nuncio Tiberi (1827-1834), Pamplona, 1976, págs. 75, 94, 106, 124, 132, 238-239, 257 y 260. GARCíA Lово, Santa María de Arbas, pág. 113.

97 Los documentos fechados durante la larga prelacía de don Ignacio Álvarez Brasón aseguran que la administración estaba por lo común en manos de sus apoderados. Sólo en muy pocos figura el abad presente en Arbas y sus contornos. Véase por vía de ejemplo: AHA, PL, 10518: Protocolo del año 1802. Escribano Pedro 


\section{A finales del siglo XVIII, tras un periodo de turbulencias y discusiones en el}

que, según hemos visto, la colegiata estuvo a punto de desaparecer, la Corona presentó para la abadía a un clérigo ovetense, cuyo nombre y apellidos nos indican la íntima relación que tenía con nuestro hacendista ${ }^{98}$. Se trata de don

Antonio de Aza Muñiz, f. 224 -224 vto.: Escritura de poder otorgada por el licenciado don Ignacio Álvarez Brasón, abad de la colegiata de Nuestra Señora de Arbas del Puerto a favor del procurador Bernardo García Castañón, que lo es del número del juzgado ordinario de Pola de Lena, para pleitos. Pola de Lena, 22 de noviembre de 1802; f. 225-225 vto.: Escritura de poder otorgada por el licenciado don Ignacio Álvarez Brasón, abad de la colegiata de Nuestra Señora de Arbas del Puerto, a favor de don José Fernández Caso, procurador del número en el Consejo Real, para que los represente en el litigio que tiene con los vecinos de San Mames de Cubillas, en el concejo de la abadía sobre la presentación del beneficio curado de este lugar. Pola de Lena, 22 de noviembre de 1802. AHA, PL, 10491: Protocolo del año 1816. Escribano Fernando González Escalada, ff. 86 vto.-87 vto.: Escritura de poder otorgada por el licenciado don Ignacio Álvarez Brasón, abad y administrador principal del Real Hospital de Arbas, don Domingo Antonio de la Robla y Redonda, don José Suarez Quirós y don Juan García Campomanes, canónigos, todos prebendados de la colegiata de Nuestra Señora de Arbas del Puerto, a favor de don Juan González de Lena y don Juan Menéndez, vecinos de la villa de Pajares, para que hagan las gestiones convenientes a fin de que el Real Consejo de la Cámara les dé licencia para aforar la mortera de prado monte y matorral llamada de Pajares. Río de Argayo, términos del Puerto de Pajares (Asturias), 10 de septiembre de 1816. AHA, PL, 10492: Protocolo del año 1818. Escribano Fernando González Escalada, s. fol.: Escritura de poder otorgada por el licenciado don Ignacio Álvarez Brasón, abad, don Francisco Díaz, don José Suarez Quirós, don Juan García Campomanes, don José Martínez de Vega, don Juan Álvarez Castañón, don Juan Fernández Cienfuegos y don Gregorio Menéndez, canónigos, todos prebendados de la colegiata de Nuestra Señora de Arbas del Puerto, a favor del doctor don Pedro Pertierra, para que los defienda en un litigio que tiene con los vecinos del concejo de la Abadía, sobre la ejecución de una sentencia que condenaba al abad y capitulares que habían sido de la referida iglesia. Rodregaio, términos de Pajares (Asturias), 7 de junio de 1817. AHA, PL, 10492: Protocolo del año 1817, s. fol.: Escritura de poder otorgada por el licenciado don Ignacio Álvarez Brasón, abad de la colegiata de Nuestra Señora de Arbas del Puerto, a favor de don Nicolás Cordero Solís, vecino de Murias (Aller, Asturias), para que administre los bienes raíces pertenecientes a la dicha abadía en el referido concejo de Aller. Rodregayo, términos de Pajares (Asturias), 7 de junio de 1817. AHA, PL, 10492: Protocolo del año 1818, s. fol.: Escritura de poder otorgada por el licenciado don Ignacio Álvarez Brasón, abad de la colegiata de Nuestra Señora de Arbas del Puerto, a favor de don Tomás Figuero, procurador del número de la Real Chancillería de Valladolid, para que acuda a este tribunal y pida la habilitación necesaria para proceder a los apeos de los bienes de la dicha abadía en los reinos de Castilla y León. Pajares (Asturias), 1 de septiembre de 1818. AHA, PL, 10528: Protocolo del año 1825. Escribano Pedro Antonio de Aza Muñiz, f. 66-66 vto.: Escritura de poder otorgada por don Ignacio Álvarez Brasón, abad de la colegiata de Nuestra Señora de Arbas del Puerto, a favor de don Isidro Fernández Blanco, secretario de la Real Chancillería de Valladolid, en materia procesal. Pola de Lena, 29 de marzo de 1825. AHA, PL, 10528: Protocolo del año 1825. Escribano Pedro Antonio de Aza Muñiz, f. 170-170 vto.: Escritura de poder otorgada por don Ignacio Álvarez Brasón, abad de la colegiata de Nuestra Señora de Arbas del Puerto, a favor de don Jerónimo Fernández para que administre los bienes y derechos de la referida iglesia, sus memorias y hospitales, sitos en la villa de Mayorga de Campos y sus términos. Pola de Lena, 3 de diciembre de 1825.

98 No se ha podido encontrar el año en que comenzó la prelacía de don Ignacio Álvarez Brasón. García Lobo pone como abad anterior a él a don Santiago de Robles Castañón, muerto el 23 de enero de 1787, pero como la nómina de este abadalogio dista mucho de ser completa, no se sabe si fue aquél su sucesor inmediato. Lo cierto es que tras el fallecimiento de Robles Castañón hubo un tiempo largo de vacante que continuaba el 11 de mayo de 1791, pues en esta fecha se titula el canónigo don Juan de Robles «vicario general pro capitulo sede abacial vacante». Por esto hay que suponer que don Ignacio fue su sucesor. La causa de la tardanza en cubrir esta vacante se debió a que por entonces se estaba tratando de suprimir la colegiata para dotar las cátedras de la Universidad de Oviedo (García Lobo, Santa María de Arbas, págs. 105 y 113). 


\author{
Ignacio Álvarez Brasón ${ }^{99}$ y Canga Argüelles ${ }^{100}$, es decir, su primo hermano, hijo \\ de doña María Josefa y del esposo de ésta don Gregorio Álvarez Brasón y de \\ Ororvia ${ }^{101}$.
}

99 En la documentación de los siglos XVIII y XIX, la principalmente empleada en este trabajo, se escribe el apellido del abad como Blasón. Sin embargo, ésta no es la forma originaria y auténtica. Los documentos más antiguos que se conservan, del siglo XVI, unánimemente lo ponen como Brasón. De ahí que aquí se adopte esta forma. ARCHV, Registro de ejecutorias, caja 241, 26: Ejecutoria en el pleito entre Fernando Álvarez Brasón, vecino del concejo de Somiedo, y Juan de Muros, vecino de San Juan de Leñapañada. 13 de octubre de 1509. AHN, Inquisición de Toledo, 268, 8: Pruebas de limpieza de sangre de Lorenzo Álvarez Brasón, vecino de Toledo y natural de El Coto de Buenamadre (Somiedo, Asturias), para el oficio de notario del tribunal de la Inquisición de Toledo (1640-1641). A partir del siglo XVIII, aunque con alguna manifestación en el anterior sobre todo en documentos de fuera de Asturias, comenzó a generalizarse la forma Blasón, que parece ser una forma castellanizada del apellido. Archivo General de Indias, Sevilla, Patronato, 152, N. 12, R. 1: Información para el Consejo de Indias sobre los méritos y servicios del capitán de infantería Pedro Menéndez Blasón, alcaide del castillo de Portovelo en Panamá, promovida por su viuda doña Francisca de Cuvillas. Panamá, 22 de mayo-3 de julio de 1628.

100 APSTO, Libro IV de Bautismos de la parroquia de San Tirso El Real de Oviedo, f. 192 vto.: «[Al margen: Ignacio Leoncio Álvarez Blasón. 357] En trece de setiembre de mil setecientos sesenta y un años, don Juan Menendez Camina, presbítero, bautizo solemnemente con mi especial licencia, en esta iglesia parroquial de San Tirso el Real a un niño que nació el día doce del mismo mes, y se llamo Ignacio Leoncio, hijo legítimo de Gregorio Álvarez Blasón, bautizado en la parroquia de San Saturnino de la ciudad de Pamplona, y de Josefa Canga Argüelles, su mujer, bautizada en ésta de San Tirso. Fue su padrino don Felipe Canga Argüelles, tio del bautizado, a quien se advirtieron las obligaciones que contrajo. En cuya fe lo firmo como cura propio de esta dicha parroquia [Firmado: Licenciado Francisco Rodriguez Castañon]».

101 Este don Gregorio Álvarez Brasón y de Ororbia había nacido en Pamplona el 17 de julio de 1734 y falleció en Oviedo el 24 de mayo de 1769. El apellido de la madre de éste era el navarro Ororbia, y no Orbiz. Cfr. Emilia Lareo Sola, «El archivo familiar Fernández Blanco y Sierra Pambley. Retrato de un fondo documental único», Ideas reformistas, pág. 363. Archivo de la Parroquia de San Saturnino, Pamplona, Libro 6. ${ }^{\circ}$ de Bautizados, f. 23 vto.: «[Al margen: Alexo Gregorio Albarez] En diez y ocho de julio del año de mil setecientos treinta y cuatro yo el vicario infraescrito de la parrochial de San Saturnino de esta ciudad bautize a un niño llamado Alexo Gregorio hijo legitimo de Thomas Albarez y de Maria Joachina de Ororbia natural de Artajona coniuges residente en esta parrochia: nació dicho niño en diez y siete de dicho mes y año: fue su padrino Gregorio Osacar natural de esta ciudad a quien adverti la cognación espiritual y firme [Firmado: Licenciado Joachin de Muru]». APSTO, Libro II de Matrimonios, f. 111 vto.: «[Al margen: Velaronse] Gregorio Alvarez Blason y María Josefa Canga Argüelles. En trece de diciembre de mil setecientos cincuenta y ocho años don Diego Peon Solares, arcipreste de Oviedo, cura propio de San Pedro del Otero, en virtud de licencia y despacho del señor provisor y vicario general de este obispado, a que me refiero, asistió al matrimonio que solemnemente contrajeron entre si Gregorio Alvarez Blason, hijo legitimo de Tomas Alvarez Blason y de Joaquina de Ororbia, vecinos de la parroquia de San Isidoro de esta ciudad, y Maria Josefa Canga Argüelles, hija legitima de Jose Canga Argüelles y de Maria Perez de la Sala, vecinos de esta de San Tirso el real, habiéndose dispensado por el citado despacho las tres proclamas que el Santo Concilio de Trento manda. Fueron testigos de este matrimonio don Manuel del Riego Faes y don Agustin Obañez, vecinos de esta dicha parroquia de San Tirso. En cuya fe y en virtud de certificacion del referido don Diego, que queda con el despacho en mi poder, la firmo como cura propio de ella [Firmado: Francisco Rodriguez Castañon]». APSTO, Libro III de Difuntos, f. 66: «Gregorio Alvarez Blason. En veinte y cuatro de mayo de mil setecientos y sesenta nueve, falleció don Gregorio Alvarez Blason, marido de doña Josefa Canga Argüelles, de cuyo matrimonio quedaron hijos legitimos Ignacio, Francisco y Juaquina. No recibió los Santos Sacramentos por no haber dado lugar el accidente de que falleció, ni hizo testamento. Enterrose en el convento de San Francisco, con mi licencia. De todo lo cual, doy fe y lo firmo [Firmado: Bernardo Perez Noriega]». Archivo de la parroquia de San Isidoro El Real de Oviedo (APSIO), Libro 6. ${ }^{\circ}$ de Difuntos (1790-1833), f. 122 vto.: «Doña Francisca Canga. En veinte y 
No hay duda de que la ventajosa promoción de este eclesiástico se debió a las influencias y recomendaciones que en la Corte pudo mover su familia materna, entonces presente en los altos círculos de la administración. Se da además la circunstancia de que estos parientes colaterales de don José figurarían con relevancia en los anales del liberalismo español ${ }^{102}$. Prima carnal del hacendista y hermana también del abad fue doña Joaquina ${ }^{103}$, esposa de don Felipe de Sierra Pambley, que sería ministro de Hacienda durante el Trienio Liberal ${ }^{104}$.

\footnotetext{
tres de octubre de mil setezientos nobenta y nuebe fallecio en esta parroquia doña Francisca Canga viuda de don Gregorio Blason y vezino de ella socorrido de los Santos Sacramentos de Penitencia Sagrada Eucharistia y Extremaunzion pero sin hacer testamento dejo por sus hijos lexitimos al lizenciado don Ygnacio Albarez Blason abad de la Colexiata de Arbas y a doña Joaquina. Diose sepultura a su cadaber en la yglesia de los regulares de nuestro padre san Francisco de esta ciudad el dia veinte y cinco siguiente y para que conste lo firmo [Firmado: Don Josef Antonio Cuerbo]». Don Gregorio y doña María Josefa tuvieron al menos cuatro hijos, doña María Francisca, don Ignacio, don Francisco Javier y doña Joaquina. APSTO, Libro IV de Bautismos, f. 180 vto.: «[Al margen: Maria Francisca Alvarez Blason. 271] En diez y ocho de setiembre de mil setecientos cinquenta y nueve años don Juan Menendez Camina escusador, bautizo solemnemente en esta iglesia parroquial de San Thirso el Real a una niña que nació el dia diez y siete del mismo mes, y se llamo Maria Francisca del Carmen, hija legitima de Alexos Gregorio Alvarez Blason y de María Josepha Canga Argüelles, su muger: fueron sus padrinos Joseph Canga Argüelles y Joachina Olorvia, avuelos de la bautizada: en cuya fe lo firmo como cura propio de esta dicha parroquia [Firmado: Lizenciado Francisco Rodriguez Castañon]»; f. 207 vto.: «[Al margen: Francisco Xavier Alvarez Blason. 444] En veinte y siete de setiembre de mil setecientos sesenta y tres años don Alvaro Menendez, mi escusador, bautizo solemnemente en esta iglesia parroquial de San Thirso el Real a un niño, que nació en veinte y seis de el mismo y se llamo Francisco Xavier, hijo legitimo de Gregorio Alvarez Blason, bautizado en la de San Sarturnino de la ciudad de Pamplona, y de Josepha Canga Argüelles su muger, bautizada en esta de San Thirso, mis feligreses: fueron sus padrinos don Domingo Suarez tonsurado, y doña Francisca Requexo Tineo, que no contraxo, vecinos de esta ciudad, a quienes se advirtieron sus respetivas obligaciones: en cuya fe yo el lizenciado don Francisco Rodriguez Castañon, cura propio de esta dicha parroquia de San Thirso, lo firmo [Firmado: Lizenciado Francisco Rodriguez Castañon]». APSTO, Libro de Difuntos (1753-1798), f. 156 vto: «[Al margen: Don Francisco Alvarez Blason. 428] En quatro de agosto de mil setezientos noventa y dos años murió en la parroquia de San Tirso el Real de la ciudad de Oviedo don Francisco Blason, mi feligres, natural de esta dicha parroquia hixo lexitimo de don Gregorio Blason, difunto, y de doña Josefa Canga Argüelles su muxer: no recibió el sagrado viatico por hallarse de unos meses a esta parte con la mente turbada, y asi recibió la extremaunción, y sub conditione el sacramento de Penitencia, y se dio con mi licencia sepultura a su cadáver al siguiente dia en la yglesia de San Francisco de esta dicha ciudad en cuya fe lo firmo como cura propio de la referida de San Tirso [Firmado: Doctor don Sebastian Velez de Cossio]».

102 Cfr. Isabel Cantón Mayo, La Fundación Sierra-Pambley. Una institución educativa leonesa, León, 1995, págs. 28-35 y 39-86.

${ }_{103}$ APSTO, Libro IV de Bautismos, f. 250: «Joaquina Juana Alvarez Blason. 166. En ocho de mayo de mil setecientos sesenta y nueve, yo don Bernardo Perez Noriega, presbítero tenente cura de esta parroquia de San Tirso el Real bautice solemnemente una niña que nacio el dia siete de dicho mes y se llamo Joaquina Juana, hija legitima de don Gregorio Alvarez Blason, natural de la parroquia de San Saturnino de Pamplona, y de doña Josefa Canga Argüelles, natural de esta de San Tirso. Fue su padrino Thomas Alvarez Blason, abuelo de la bautizada. Y lo firmo dicho dia [Firmado: Bernardo Perez Noriega]».

104 Fue nombrado ministro de Hacienda el 28 de febrero de 1822 (Gaceta de 2 de marzo de 1822). Lo desempeñó hasta el 5 de agosto del mismo año. García Madaria, Estructura, pág. 297. Cantón Mayo, La Fundación, pág. 29. E. de DiEgo Garcia, «Felipe Sierra Pambley: una figura leonesa en la política liberal de 1820 a 1822», Tierras de León, 61 (1995), págs. 3-13.
} 
Los Brasón o Álvarez Brasón eran una familia patricia del asturiano concejo de Somiedo, que terminaría por avecindarse en Oviedo ${ }^{105}$. Eran titulares de un mayorazgo fundado en 1640 por Pedro Álvarez Brasón ${ }^{106}$. En Somiedo, a lo largo de los siglos XVI y XVII formaban parte de la cúspide de la nobleza comarcana, enlazada con otras estirpes de solares conocidos como los Flórez, Alba Valcarce, Buelta Lorenzana, Peláez de Caunedo, Miranda, Arias de la Pola o Cuenllas Lorenzana ${ }^{107}$. En el siglo XVIII, Tomás Álvarez Brasón ${ }^{108}$ pasó a Oviedo ${ }^{109}$ y, a pesar de sus orígenes, lo cierto es que su posición en la capital a

105 Archivo del Ayuntamiento de Somiedo, caja 4, leg. 12: Padrón del concejo de Somiedo del año 1717. Parroquia de San Miguel de la Llera, Coto de Buenamadre: «Lorenzo Albarez Brason hijodealgo notorio»; caja 5, leg. 1: Padrón del concejo de Somiedo del año 1766. Parroquia de San Miguel de la Llera, Coto de Buenamadre: «Pedro Albarez Brason hijodalgo notorio y este hijo de Lorenzo Albarez Brason que vive este tiene la misma facultad que el de arriba por heredarlo de el que se dice. Thomas Albarez Brason hijodalgo notorio e hijo de el de arriba y asi mismo se alista por tal hijodalgo notorio al Gregorio Albarez Brason por ser este hijo del dicho Tomas y nieto de Lorenzo Albarez Brason y todos con la igualdad conformidad ydalgos notorios en lo que aprueban los contadores a mi presencia de que doy fee y dicho Gregorio tiene por sus hijos ciertos aunque en la ciudad de Oviedo a Ignacio y Francisco por lo que les tienen y reputan por la igualdad de sus padres y abuelos».

106 Archivo de la Casa y Mayorazgo de Abol Brasón. Sin catalogar. Escritura de venta otorgada por doña Joaquina Álvarez Brasón, con licencia de su marido el licenciado don Felipe de Sierra Pambley, vecinos de Villablino, de los bienes del mayorazgo de los Brasones a favor de Pedro de Abol, vecino del El Coto de Buenamadre (Somiedo, Asturias), primo de doña Joaquina, y de la hija de éste, Isidora de Abol, residente en Torre (Babia de Arriba, León), por cantidad y precio de 3300 reales: «Dijo que en el lugar de Coto de Buenamadre concejo de Sumiedo en el Principado de Asturias y por cesión que en escritura de capitulaciones le hizo su hermano el señor don Ygnacio Alvarez Blason abad de la yglesia colegiata de Arbas del Puerto posee un vinculo que fundo Pedro Alvarez Blason su causante sobre varios y diferentes vienes raizes que resultan de su testamento que paso a testimonio de Diego Perez escribano de aquella xurisdicion en veinte y ocho de diciembre de mil seiscientos y cuarenta». Villablino (Laciana, León), 12 de enero de 1806.

107 Al trasladarse una línea de esta estirpe a Oviedo hubo de probar su nobleza en 1758. AAO, B-38. Justificaciones de hidalguía de los años 1740-1780, ff. 632-639: Pruebas de nobleza de Tomás Álvarez Brasón y Rodríguez de Cuenllas (año 1758). AAO, B-47, 1. Padrón de la ciudad de Oviedo del año 1766, feligresía de San Isidoro, calle de Puertanueva, f. 91 vto.: «Thomas Alvarez Blason, hijodalgo». AAO, B-47, 2. Padrón de la ciudad de Oviedo del año 1773, feligresía de San Isidoro, calle de Puertanueva, f. 20: «Thomas Alvarez Blason, hijodalgo». AAO, B-47, 3. Padrón de la ciudad de Oviedo del año 1780, feligresía de San Isidoro, calle de Puertanueva, f. 25 vto.: «Thomas Alvarez Blason hijodalgo». Véanse también los alistamientos citados en la nota 51.

108 AHDO, 56. 5. 1. Libro de bautizados de la parroquia de San Miguel de la Llera (Somiedo) (16901755), f. 25 vto.: «Thomas. En cuatro de octubre de mil setecientos y quatro años io don Rodrigo de Mirandsa Argüelles cura de la parroquia del Coto y su anejo en el concejo de Somiedo bauptice solemnemente un niño que se llamo Thomas hijo legitimo de Lorenzo Alvarez Blason y Ana Rodriguez Quenllas, fueron sus padrinos Juan Alvarez y María Lana vecinos de esta parroquia y por ser verdad lo firmo dicho dia mes y año [Firmado: Rodrigo de Miranda Argüelles]».

109 Archivo de la Casa y Mayorazgo de Abol Brasón, sin catalogar: Escritura otorgada por doña María Manuela Ponce de León, abadesa, y la comunidad de monjas cistercienses del real monasterio de Santa María de las Huelgas de Avilés, y por Tomás Álvarez Brasón, vecino de Oviedo, en la que las primeras dan en foro la mitad de la tierra llamada La Corradona en términos de El Coto de Buenamadre (Somiedo) al segundo por tiempo de vidas de tres reyes y por renta anual de una anega de trigo y tres libras de manteca cocida. Portería principal del real monasterio de San Bernardo de las Huelgas de Avilés, 4 de marzo de 1761: «Thomas Albarez Brason, vezino de la ciudad de Obiedo, y oriundo de el Coto de Buena Madre, en el consejo de Somiedo». 
mediados de la centuria no superaba un discreto pasar: era estanquero al por menor de tabacos, mayoral del hospicio y además, para completar sus ingresos, daba posada a los transeúntes. Disponía de servicio doméstico, lo que indica cierto acomodo ${ }^{110}$.

La denominada desamortización de Godoy dio ocasión a un trasvase de propiedad importante ${ }^{111}$. En este caso no todos los que fueron enajenados se consideraron por la autoridad civil eclesiásticos, y sí afectos a la beneficencia. Un monarca tan catolicísimo como Felipe II se había visto obligado a la alienación de derechos de la Iglesia valido de la autoridad pontificia ${ }^{112}$. La operación no suponía que las instituciones afectadas quedaran sin rentas, sino que los ingresos que hasta entonces percibían procedentes de bienes raíces se convertían en un derecho sobre la Real Hacienda ${ }^{113}$. La enajenación, en los casos que se creyó imprescindible, contaba con la licencia de la Santa Sede, pues el papa Pío VI como administrador supremo del dominio canónico la había concedido ${ }^{114}$. Sin embargo amplios sectores de la sociedad acogieron esta desamortización con notorio desagrado, la acusaron de vulnerar el derecho de propiedad e incluso la calificaron de impía ${ }^{115}$. No hay duda de que las circunstancias de la época hicieron virulentas opiniones que en otro tiempo no hubieran sido tan radicales. Y posiblemente lo que terminó por conseguir un juicio tan adverso fue la pésima

AAO, B-38. Justificaciones de hidalguía de los años 1740-1780, ff. 632-639: Pruebas de nobleza de Tomás Álvarez Brasón, vecino de Oviedo (1758).

110 AAO, B-128. Oviedo. Tomo 1. Ciudad de Oviedo y su concejo. Copia del Libro Segundo de Seglares. Oviedo, 30 de mayo de 1753, f. 111-111 vto.: «Thomas Albarez Blason, estanquero por menor de tabacos hijodalgo de quarenta y seis años, casado con Joachina Olorbia, tiene a Gregorio de diez y siete Antonia y Agustina menores sus hijos y a Maria Fernandez su criada que la da de comer y sesenta y seis reales tiene de sueldo por dicho estanquillo mil quatrocientos y sesenta reales. Es maioral de el hozpizio porque le pagan seiscientos ochenta y siete reales y dos maravedís, dedicase a dar posada por que le regulan quarenta reales que todo haze al año mil ochocientos ochenta y siete y dos maravedís». AAO. B-136. Oviedo. Tomo 9. Respuestas particulares, ff. 6989 vto.-6990: Bienes de Tomás Álvarez Brasón, vecino de Oviedo. Los únicos bienes con los que figura son diecisiete cabezas de ganado mayor en los concejos de Oviedo y Morcín dados en aparcería. Se ve que la vivienda en la que vivía en Oviedo no era de su propiedad. Sí consta que tenía bienes inmuebles, entre ellos los de su mayorazgo en el concejo de Somiedo. APSIO, Libro núm. 5 de Difuntos (17711790), f. 108: «[Al margen: Thomas Alvarez Blason] En la calle de la Magdalena de esta parroquia de San Ysidoro el Real de la ciudad de Oviedo a diez y siete días del mes de septiembre de mil setecientos ochenta y dos años murió Thomas Alvarez Blason, viudo de Joaquina Ororvia, recibió los santos sacramentos, testo por testimonio de Juan de la Escosura escrivano de esta ciudad, dejo dos hijas, doña Antonia y doña Agustina, eligio sepultura en el convento de San Francisco, en donde se le enterro, y para que conste lo firmo [Firmado: Doctor don Joseph Antonio de Lago]».

111 Sobre la normativa civil y canónica — cuando ésta se consideró necesaria — véase principalmente:

Martí Gilabert, La Iglesia, págs. 239-240. Friera Fernández, La desamortización, págs. 97-117.

112 FaYa Díaz, Los señoríos, págs. 255-257.

113 Friera Fernández, La desamortización, págs. 99, 107 y 110.

114 Martí Gilabert, La Iglesia, págs. 239-240. Friera Fernández, La desamortización, págs. 106 y 110.

115 Friera Fernández, La desamortización, págs. 173-177. 
gestión y los nefastos resultados a que dio lugar, cuando la Corona apenas obtuvo provecho y las instituciones desamortizadas muy tempranamente dejaron de recibir sus rentas ${ }^{116}$. Los únicos que se beneficiaron fueron los compradores. Esto último dio a la operación un tono de corrupción y fraude que hizo que algunos de sus gestores pagaran con su vida la participación en tal acto. En el fatídico año 1808, con la caída de Godoy, la persecución y el crimen recayó sobre ellos ${ }^{117}$.

El propio Sierra Pambley, primo político de Canga Argüelles, se vio amenazado y tuvo que sufrir los desaires que entonces padecieron los amigos del ministro caído ${ }^{118}$. Tanto en la ciudad de León como en la provincia se produjeron desordenes muy serios en los que fueron gravemente molestados, no sólo el propio don Felipe, juez comisionado para la venta de los bienes desamortizados, sino los subalternos ${ }^{119}$.

La discutible desamortización del reinado de Carlos IV afectó también sustancialmente a la colegial de Arbas. Entre los bienes que se vendieron por la Corona se incluyó, precisamente, el coto de Lindes ${ }^{120}$. Con ello se asestó un golpe letal a la decadente labor hospitalaria que desempeñaba la colegiata $^{121}$. El traspaso de la titularidad tuvo lugar en $1808^{122}$ y el comprador fue precisamente don José Canga Argüelles, primo hermano del señor administrador saliente, es decir don Ignacio Álvarez Brasón. Todo quedaba por lo tanto en familia. Y hasta tal punto este negocio fue doméstico y hogareño que el propio don Felipe de Sierra Pambley también se ocupó de desamortizar los bienes de los hospitales de Arbas ${ }^{123}$.

\footnotetext{
116 Martí Gilabert, La Iglesia, págs. 253-254. Friera Fernández, La desamortización, pág. 177.

117 Friera Fernández, La desamortización, págs. 197- 200.

118 Waldo MErino, Los orígenes del régimen constitucional y la resistencia leonesa a Napoleón. La Junta Superior del reino: 1808-1813, León, s. a., s. p.

119 Carantoña Álvarez, «De la Ilustración», pág. 28.

120 González García, La casa, pág. 189.

121 Tuñón Escalada, Don Agustín, pág. 206. El hospital de Arbas siguió subsistiendo, como se desprende de la documentación, pero en un estado de postración creciente. AHA, PL, 10492: Protocolo del año 1817. Escritura otorgada por don Francisco Díaz, canónigo de la colegiata de Nuestra Señora de Arbas del Puerto, nombrado tesorero de dicha iglesia por su abad don Ignacio Álvarez Brasón y con refrendo de Su Majestad, y mayordomo de los reales hospitales dependientes de ella, como principal, y por Melchor Díaz, Juan Menéndez, mayor, Juan Díaz, vecinos de Pajares, y Francisco Díaz, vecino de Llanos (Lena), como fiadores, por la que aseguran el ejercicio de aquellos empleos de tesorería y mayordomía. Pajares, 9 de octubre de 1817.

122 Fermín Canella Secades, «Quirós», Asturias, III, Gijón, 1900; ed. facs. 1987, pág. 454.

123 AHA, PL, 10492: Protocolo del año 1817. Escribano Fernando González Escalada, s. fol.: Escritura otorgada por Pedro Delgado, vecino de Sotiello (Lena), en la que traspasa a su convecino Martín Fernández Cienfuegos el prado llamado de Moniella, sito en términos del referido Sotiello, por la cantidad que le dio para pujar en la subasta de varios raíces que de la colegiata de Nuestra Señora de Arbas del Puerto se hizo por orden del licenciado don Felipe de Sierra Pambley, comisionado regio en el partido y reino de León para
} 
Por aquel entonces los Canga Argüelles, los Álvarez Brasón y los Sierra Pambley, tan estrechamente relacionados familiarmente, formaban parte de los círculos sociales que se aprovecharon de estas ventas. Empresa que no sólo estaba de acuerdo con su mentalidad ilustrado-liberal, sino también, y más, con sus ansias de enriquecimiento y de superar la situación de hidalguía provinciana.

Sobre lo que pensaba don Ignacio de los establecimientos de Arbas tenemos un testimonio valioso. En 1797 pasó por la colegiata Jovellanos ${ }^{124}$ y allí le recibió el abad ${ }^{125}$. El polígrafo gijonés nos da cuenta de la librería que tenía y de algunas de sus opiniones. En efecto, el prelado consideraba que la subsistencia de Arbas en aquellas escarpaduras era un anacronismo, por lo que hay que deducir, además de por su propio entorno familiar, que estaba imbuido de las ideas renovadoras. Sin embargo, Jovellanos pensaba que carecía de suficiente

la venta de bienes de hospitales, hospicios, casas de misericordia y otras fundaciones pías. Sotiello (Lena), 20 de diciembre de 1807. AHA, PL, 10490: Protocolo del año de 1808. Escribano Fernando González Escalada, s. fol.: Testimonio de anotación en el oficio de hipotecas de los raíces pertenecientes al hospital de Arbas en la jurisdicción de Pajares, subastados y rematados por don Antonio de Robla, canónigo de la colegiata de Nuestra Señora de Arbas del Puerto, por orden del licenciado don Felipe de Sierra Pambley, comisionado real para la venta de los bienes de hospitales y hospicios. Pajares, 2 de abril de 1808. En la documentación de la época don Felipe aparece como abogado de los Reales Consejos, juez comisionado regio de los obispados de León, Astorga y Oviedo, de puertos al sur, vicaría de San Millán y jurisdicciones vere nullius para la enajenación y venta de predios rústicos y urbanos de capellanías y segregación y venta de la séptima parte de los demás predios concedidos por autoridad apostólica, juez especial para la venta de los bienes de las obras pías de la provincia de León, en virtud de concesión papal, y contador principal de la Real Caja de Consolidación de León. El juez subdelegado era su propio padre, don Ángel, que figura con este oficio para la formación de los expedientes de las obras pías. Véanse las numerosas escrituras, por vía de ejemplo, contenidas en el Archivo Histórico Provincial de León. Protocolos de Laciana, 6726 y 6832.

124 Jovellanos, según testimonia en sus diarios, pasó varias veces por Arbas: Gaspar Melchor DE Jovellanos, Diarios, I, Oviedo, 1953, pág. 122: «[5 de septiembre de 1790] [...] poco antes Arbas, a dos tiros de fusil, compuesto todo este camino por los canónigos»; II, Oviedo, 1954, pág. 25: «[15 de abril de 1795] [...] aún más allá de Arbas. Veremos si son las peñas que pasamos por Puerto Tuero; el suelo arenoso. Nos apeamos para ir a Arbas; siguen los demás; nosotros a pie por el camino de arriba; el río interpuesto; el puente a la derecha, lejos; el de la izquierda, aunque cercano, no se puede buscar por falta de senda; gritos para llamar a quien nos pase; aparecen unos muchachos; vuelven con noticia de que nadie quiere venir; Liaño pasa montado sobre un palancón que está atravesado sobre el río, con su casaca arremangada; no me atrevo a otro tanto; el palo se mueve, cargado de ropa y papeles, no acierto a prepararme; no hay remedio: exigua prohibemur aqua; Liaño nada quiere ver; vuelve cada uno por su orilla a buscar el camino y los caballos. A corto trecho el canónigo don Francisco; instancias, a lo menos, para la vuelta; que [...] veremos»; pág. 455: «[16 de noviembre de 1797] Se pasa el puerto con algún fresco, pero sin molestia; nos recibe el abad, prior, chantre y canónigo Gutiérrez, de Arbas; Baltasar y Acebedo tiran a Busdongo. Aquel irá temprano a La Robla. En Arbas de día. Gran frío; llueve. A escribir en el Expediente reservado. Bulla. Viene Joaquín Velarde; trae el coche que ha de llevarme. Carta de Cabarrús; que me buscará en Valladolid; que Meléndez está en León; que Cabarrús va a una embajada. Yo al fin, quedaré solo, sin amigo, sin consejo, y abandonado a mi pobre y desabritado espíritu. Cena; en la cama a las once. Viernes, 17 [de noviembre de 1797]. Salimos al rayar el día. Mañana fría y húmeda; nos acompañan los que nos recibieron; se van Posada y Velarde. Tomamos por Peñagotera, para evitar la Collada».

125 García Lobo, Santa María de Arbas, págs. 82-83. 
ímpetu para acometer reformas, pues lo consideraba un genio apocado y pusilánime $^{126}$. En realidad fue un eclesiástico gris y sin mayor relevancia ${ }^{127}$. El obispo de Oviedo, el ultra Ceruelo de la Fuente, no le debió de profesar ninguna simpatía. Éste en 1816 era firme partidario de trasladar la colegial a Pola de Lena, así además favorecía a sus queridos diocesanos de este municipio, conocidos por sus ideas absolutistas ${ }^{128}$. Don Ignacio moriría en Oviedo — no había peligro

126 Jovellanos, Diarios, II, págs. 446-447: «[12 de octubre de 1797] En la Pola de Gordon nos recibe el abad de Arbas, y don Francisco, el canónigo. Seguimos por el camino de La Vid; dos veces vadeando el río; puede evitarse, tomando el camino en la otra garganta, que sale a Beberinos. Alguna piedra caliza; después toda cuarzosa. Se sube y baja bastante. Muchas estrechuras, que piden enormes desmontes. El paso de Peña Gotera, al parecer, insuperable, estrechísimo por más de 170 pasos. De nuevo se vadea el río dos veces, y aun otras dos. Villasimpliz. Adelante. En Villamanín a la una y media. Se come así. A caballo a las cuatro y media. Viento frio; luego más frío. Anochece en Busdongo. Más y más frío. Llegamos por fin helados. Buen cuartito del abad; sus libros, la Historia Eclesiástica, del Fleury, en latín, 82 volúmenes; el Antiguo y Nuevo Testamento, de Calmet, 4; la Biblioteca portátil de los padres y varios de facultad. Conversación sobre los teatros, o más bien disputa. Ítem sobre el uso del vino. Es tímido y escrupuloso. Viernes, 13 [de octubre de 1797]. Cama regalada. En pie a las ocho. A las nueve, a ver la garganta que desde la casa de Tibigratia sale a Arbas; me acompañan el abad y el arquitecto Prunedita; es un grande atajo y se evitan las ánades de la entrada de la Perruca; pero no concibo como se puede hacer por allí camino; la subida es en extremo agria; las laderas, en extremo pendientes; el valle intermedio, en extremo profundo respecto de ellas y lleno de aguas; el terreno áspero y pedregoso y deleznable; creo que se deba renunciar a tal pensamiento; veranle, sin embargo, los arquitectos a su tiempo. A ver la iglesia colegial; antigua, obscura, humeda, fría, insufrible. ¿De qué sirve en este desierto tal congregacion de clérigos secuestrados (o segregados) del trato humano? ¿De qué las limosnas dadas a holgazanes o vagamundos? ¿De qué el llamado hospital, que sólo sirve para alojarlos y atraerlos? ¿No estaría mejor trasladado a un lugar poblado del camino? De esto hablé mucho con el abad; pero aunque lo desea, no tiene espíritu para emprenderlo. Al cabo mejor pensada estaba la supresión. Comida muy aseada; temo que el tiempo se revuelva, y determino partir a caballo a las tres, con el abad y el canónigo don Francisco. Otro temple doblado el puerto. Nos acompañan hasta más acá de Flordeacebo».

127 Hay, sin embargo, que notar, que durante su abadía se realizaron algunas obras de consideración en Arbas, necesarias tras los desperfectos que ocasionaron los franceses durante la guerra de la Independencia. AHA, PL, 10491: Protocolo del año 1816. Escribano Fernando González Escalada, f. 37- 37 vto.: Escritura otorgada por los maestros de carpintería Fabián García Palacios y don Justo Bardón, vecinos respectivos de las parroquias de Piñera y Llanos, sitas en el concejo de Lena, en la que se obligan a realizar las obras que se describen en la casa del abad de Arbas, afectada por los sucesos de la guerra de la Independencia, según comisión que don Ignacio Álvarez Brasón, abad de la colegiata de Nuestra Señora de Arbas del Puerto, otorgó a favor de don Antonio de la Robla y Redonda, canónigo en la misma iglesia. Sotiello (Lena), 5 de marzo de 1816. AHA, PL, 10491: Protocolo del año 1816. Escribano Fernando González Escalada, f. 80-80 vto.: Escritura otorgada por José Roces Menéndez, vecino de Oviedo, Francisco Roces, que lo es de la villa de Noreña, y don José Argüelles Muñiz, de Campomanes (Lena), fiador, por la que se obligan como maestros de carpintería y tallistas a hacer la cajonería de la sacristía y dos retablos colaterales de la colegiata de Nuestra Señora de Arbas del Puerto, según lo tienen tratado con el licenciado don Ignacio Álvarez Brasón, abad de la referida iglesia. Campomanes, 15 de agosto de 1816.

Durante la prelacía de Álvarez Brasón, el 3 de enero de 1802, el rey reconoció a la abadía la calidad de vere nullius y a su titular jurisdicción omnímoda. Por esta época se modificó el trazado de la carretera o camino real, que trascurría algo alejado de la iglesia, y que desde entonces quedó fijado por delante de la colegiata y entre ésta y el hospital. También parece que a principios del siglo XIX se construyeron las casas para canónigos, al pie de la carretera. García Lobo, Santa María de Arbas, págs. 82-83 y 106.

128 Tuñón Escalada, Don Agustín, pág. 207. 
de que el fatal suceso le sorprendiera residiendo en su abadía ${ }^{129}$ - en $1827^{130}$. Por los papeles personales que dejó, y a falta de testamento auténtico, parece que legaba todos sus bienes a la Iglesia; sin embargo quienes al fin le heredaron fueron sus sobrinos carnales, los Sierra Pambley ${ }^{131}$, constitucionales de pro en

129 Por lo común aparece avecindado administrativamente en Oviedo. AAO, B-48, 1. Padrón de la ciudad de Oviedo del año 1794. Parroquia de San Tirso, calle del Rosal, f. 19: «Don Ygnacio Alvarez Blason canonigo en la colegiata de Santa Maria la Real de Covadonga, hijodalgo». AAO, B-49, 1. Padrón de la ciudad de Oviedo y sus arrabales del año 1801. Parroquia de San Tirso, calle del Rosal, f. 24 vto.: «El señor don Ygnacio Alvarez Blason abad de la real colegiata de Arvas hijodalgo». AAO, B-50, 1. Padrón de la ciudad de Oviedo del año 1815. Parroquia de San Tirso, calle del Rosal, f. 22: «Don Ygnacio Alvarez Blason presbítero abad de la real colegiata de Arbas hijodalgo».

130 APSIO, Libro 6. ${ }^{\circ}$ de Difuntos (1790-1833), f. 394: «El licenciado don Ygnacio Alvarez Blason abad de la real colegiata de Arvas. En diez y siete de abril de mil ochocientos veinte y siete a las doce menos tres minutos de la noche fallecio en esta parroquia de San Ysidoro el Real de la ciudad de Oviedo de la que soy cura interino en vacante el licenciado don Ygnacio Alvarez Blason presbitero abad de la real colegiata de Santa Maria de Arvas del Puerto; haviendo recibido los Santos Sacramentos de Penitencia Eucaristia y Extremauncion; su cadaber fue sepultado al dia siguiente a las siete de la tarde en la yglesia parroquial de San Julian de los Prados extramuros de esta ciudad. No se sabe si tiene o no testamento autentico, solo se hallaron dos disposiciones testamentarias en simple firmadas y escriptas de su puño por las que entre otras cosas deja a la fabrica de la yglesia e dicha Real Colejiata todos sus haver y vienes; y para que conste lo firmo [Firmado: Juan Antonio Ynfanzon]». A Álvarez Brasón debió de sucederle en la prelacía el citado Cidrón y Bernal, del hábito de Calatrava, cuyo oficio García Lobo lo documenta en los años 1828 y 1832. En pos de éste vino como abad don Manuel Flórez de Valdés, de la casa de Carvallo, en Cangas del Narcea, que fue el último. Cuando la extinción del cuerpo colegial, debió de pasar al cabildo catedral de Oviedo, en donde ocupó el arcedianato de Gordón. Falleció el 7 de julio de 1859. Don Francisco de Abol, que también era pariente lejano de Flórez de Valdés, fue el último chantre, y al suprimirse la colegiata pasó a disfrutar una canonjía en Covadonga, en donde falleció. García Lobo, Santa María de Arbas, pág. 113. Cecilia Melendez de Arvas, Prosapias de Asturias, Oviedo, 1989, pág. 50. Justo García SÁnchez, El título «Abad de Covadonga», dignidad en la catedral de Oviedo: aportación a un centenario, Oviedo, 2001, págs. 70 y 95.

131 AHA, PL, 10529: Protocolo del año 1828. Escribano Pedro Antonio de Aza Muñiz, ff. 138-139 vto.: Escritura otorgada por don Luis Díaz Faes, vecino de Pola de Lena, don Marcos Fernández Blanco y don Damián José de la Vega, mayordomo de la fabrica de la iglesia parroquial de Pola de Lena. Don Luis y don Florencio Álvarez, vecino de Pola de Lena, habían sido arrendatarios del préstamo de la parroquia de Pola de Lena entre los años 1818 y 1820, cuyas rentas debían satisfacer al abad de la colegiata de Nuestra Señora de Arbas del Puerto, don Ignacio Álvarez Brasón, difunto. El citado don Florencio no pagó su parte, debiendo abonar 2716 reales, por lo que los herederos del citado abad, don Marcos Fernández Blanco, en su nombre y en el de su cuñado don Segundo de Sierra Pambley, la reclamaron a la viuda doña Rita de la Vega y al hermano de ésta, que era fiador, don Damián José de la Vega. Don Luis Díaz Faes terció en la diferencia y se comprometió, previa suspensión de la causa judicial, a pagar 2716 reales, que eran parte de la deuda de 4195 reales que debían don Marcos y don Segundo a la fábrica de la parroquial de Pola de Lena y a su mayordomo don Damián José. En la presente escritura don Luis se compromete a pagar en los plazos fijados la cantidad de 2716 reales al mencionado don Damián José, sin renunciar a su derecho de repetición. Don Damián José se separa por la cantidad de 2716 reales que le deben don Marcos y don Segundo, y éste, en su nombre y en el de su cuñado, decaen en la reclamación que tenían contra don Damián José (Pola de Lena, 24 de febrero de 1828). AHA, PL, 10529: Protocolo del año 1828, Escribano Pedro Antonio de Aza Muñiz, ff. 141-142: Obligación otorgada por don Francisco Álvarez, alias Nozaleza, y don Agustín del Fueyo, vecinos de la parroquia de Puente de los Fierros, y su hijuela Congostinas, en Lena, en la que se comprometen a pagar el 31 de diciembre del año corriente a don Marcos Fernández Blanco, por sí y como apoderado de su cuñado don Segundo de Sierra Pambley, únicos herederos de don Ignacio Álvarez Brasón, difunto, abad que fue de la colegiata de Nuestra Señora de Arbas del Puerto, la cantidad de 7539 reales y 26 maravedíes, que es la que deben 
tierras leonesas, que terminarían por vincularse a la Institución Libre de Enseñanza $^{132}$. Siendo prelado de Arbas, siguió la práctica común en estos casos y protegió a uno de sus parientes, bisnieto de su tía abuela María Álvarez Brasón y Rodríguez de Cuenllas, don Francisco Antonio de Abol y Álvarez Cánones, al que tuvo consigo en Arbas y que terminaría por ser canónigo de la colegiata y su último chantre ${ }^{133}$.

El matrimonio entre doña Joaquina Álvarez Brasón y Canga Argüelles y don Felipe de Sierra Pambley tuvo lugar a principios del siglo XIX ${ }^{134}$. Y

como arrendatarios que han sido del préstamo de la parroquia de Murias (Aller, Asturias), según contrato que los otorgantes habían suscrito con el dicho abad (Pola de Lena, 24 de febrero de 1828). AHA, PL, 10529: Protocolo del año 1828. Escribano Pedro Antonio de Aza Muñiz, f. 176-176 vto.: Escritura de poder otorgada por don Gregorio Menéndez, canónigo, mayordomo y fabriquero de la colegiata de Nuestra Señora de Arbas del Puerto, a favor de don Marcos Fernández Blanco, vecino de Hospital de Órbigo y sobrino del abad difunto de dicha iglesia don Ignacio Álvarez Brasón, y como tal persona interesada, para que tome y liquide cuentas con don Manuel Pérez, a cuyo cargo estuvo hasta el año de 1825 la pensión que aquella colegiata tenía sobre la mitra y obispado de Ávila (Pola de Lena, 18 de marzo de 1828). AHA, PL, 10533: Protocolo del año 1834. Escribano Pedro Antonio de Aza Muñiz, f. 269-269 vto.: Carta de pago otorgada por don Domingo de Vega, canónigo de la colegiata de Nuestra Señora de Arbas del Puerto, como apoderado de don Marcos Fernández Blanco, vecino de León, procurador a Cortes, comisario de Guerra y heredero de don Ignacio Álvarez Brasón, difunto, abad que ha sido de la citada iglesia, a favor de don Lorenzo González Pérez, vecino de Campomanes (Lena), de la cantidad de 10970 reales que éste debía a don Ignacio, como arrendatario del préstamo de la parroquial de Pola de Lena (Campomanes, 10 de noviembre de 1834).

132 Cantón Mayo, La Fundación, págs. 87-91. Pablo Celada Perandones, «Paco Sierra: hombre público, político y parlamentario», Ideas reformistas, págs. 315-326. José María MARco, Francisco Giner de los Ríos. Pedagogía y poder, Madrid, Ciudadela Libros, 2008, pág. 315.

133 AHA, PL, 10492: Protocolo del año 1818. Escribano Fernando González Escalada, s. fol.: Sustitución de poder otorgada por don Juan Fernández Cienfuegos, presbítero y canónigo de la colegiata de Santa María de Arbas del Puerto, del que le había otorgado el licenciado don Ignacio Álvarez Brasón, abad de la dicha iglesia, a favor de don Francisco Antonio de Abol, presbítero y familiar de dicho abad, residente en la mentada colegiata (Campomanes, 17 de julio de 1818). AHA, PL, 10492: Protocolo del año 1818. Escribano Fernando González Escalada, s. fol.: Escritura de poder otorgada por el licenciado don Ignacio Álvarez Brasón, presbítero y abad de la colegiata de Nuestra Señora de Arbas del Puerto, a favor de don Francisco de Abol, presbítero, su familiar y residente en la referida colegiata (Pajares, [roto el día y mes] de 1818). AHA, PL, 10493: Protocolo del año 1819. Escribano Fernando González Escalada, s. fol.: Escritura de poder otorgada por el licenciado don Ignacio Álvarez Brasón, abad de la colegiata de Nuestra Señora de Arbas del Puerto, a favor de don Norberto Fernández Barbado, vecino del concejo de Lena, a todos los efectos y en lo que toca a los bienes y derechos de la referida abadía, con suspensión del concedido a su familiar don Francisco de Abol (Pajares, 12 de enero de 1819). AHA, PL, 10529: Protocolo del año 1828. Escribano Pedro Antonio de Aza Muñiz, f. 352-352 vto.: Poder otorgado por don Francisco de Abol, canónigo de la colegiata de Nuestra Señora de Arbas del Puerto, a favor de don Andrés Quintana y Clariana, agente de número de España e Indias, residente en Madrid, para que le represente en el pleito pendiente en el tribunal de la Nunciatura Apostólica, con don Casto García Sanfrechoso, cura de la parroquia de San Juan de Beleño (Ponga, Asturias), sobre el beneficio curado de Santiago de Pigüeces y su anejo Santullano, en Somiedo (Pola de Lena, 23 de septiembre de 1828).

134 Afirma Carantoña que se acordaron estos esponsales en 1801. En efecto, en Villablino el 21 de mayo de 1801, don Ángel de Sierra Pambley y Boto y su mujer doña Javiera Fernández Téllez de Cuenllas y Meléndez Lorenzana dieron licencia a su hijo don Felipe para que contrajera matrimonio con doña Joaquina Álvarez Brasón y Canga Argüelles. De este enlace hubo dos hijos que llegaron a la madurez, doña María 


\section{estamos de nuevo ante una estirpe de patriciado ${ }^{135}$ modesto e incluso poco relevante $^{136}$. Procedentes del concejo de Cangas del Narcea y del montuoso}

(1805-1845), que casó en 1824 con don Marcos Fernández Blanco y Martínez, y don Segundo (1807 o 1808 1873), que permaneció soltero. En 1817 figura otra hija, doña Vicenta, de la que no se tiene más noticia, por lo que parece deducirse que debió de fallecer tempranamente sin tomar estado. Los citados don Marcos y doña María fueron padres de don Pedro (1832-1883), don Francisco (1827-1915), que fue el instituyente de la Fundación Sierra Pambley —ambos fallecieron solteros_, y doña Victorina (1829-1888), esposa de don Juan Posada Herrera (1812-1855), que tuvo descendencia. Doña Joaquina Álvarez Brasón falleció tempranamente, pues en 1817 ya se la considera muerta en la documentación. AHN, Estado, Carlos III, exp. 1801: Pruebas de don Felipe de Sierra Pambley y Fernández Téllez de Cuenllas, ff. 23-25: Diligencia con Lázaro de Lama, escribano del número de Laciana. Villablino, 16 de junio de 1820, f. 24-24 vto: Escritura otorgada por don Ángel de Sierra Pambley y su esposa doña Javiera Fernández Téllez, vecinos de Villablino (Laciana, León), en la que otorgan licencia matrimonial a su hijo don Felipe para que celebre nupcias con doña Joaquina Álvarez Brasón, residente en la colegiata de Nuestra Señora de Arbas, en casa de su hermano, el abad de dicha iglesia don Ignacio; ff. 33-35: Diligencia sobre los padrones del concejo de Laciana. Rioscuro (Laciana), 16 de junio de 1820, f. 34 vto.: Asientos del padrón del concejo de Laciana del año 1817. Cantón Mayo, La Fundación, págs. 25-39. Lareo Sola, «El archivo familiar», pág. 358. Carantoña Álvarez, «De la Ilustración», pág. 25. Elena Aguado Cabezas, «Segundo Sierra Pambley y Fernando de Castro. Dos liberales leoneses en la era isabelina», Ideas reformistas, pág. 202.

135 Don Felipe de Sierra Pambley fue nombrado caballero numerario de la orden de Carlos III por decreto de 26 de mayo de 1820. Hechas las pruebas, fueron aprobadas el 17 de agosto siguiente. Por ellas demostró su nobleza, limpieza de sangre y limpieza de oficios.

136 Los autores suelen repetir el origen noble por parte paterna y materna de don Francisco Fernández Blanco de Sierra Pambley, último señor de la casa de los Sierra Pambley de Villablino. Evidentemente no nos encontramos, otra vez, ante una estirpe de la primera esfera. Los Fernández Blanco se incorporaron al estamento hidalgo cuando ya la división estamental estaba experimentando una indiscutible decadencia. A mediados del siglo XVIII, Antonio o José Antonio Fernández — abuelo paterno de don Marcos Fernández Blanco, esposo de doña María de Sierra Pambley y por ende yerno de don Felipe, y padre del citado don Franciscotodavía está alistado como pechero y arrendatario de rentas eclesiásticas. El ingreso de los Sierra Pambley en el estamento nobiliario del concejo de su residencia, Laciana, en las montañas de León, también fue tardío. Don Ángel de Sierra Pambley, padre de don Felipe, consiguió sentencia ejecutoria de hidalguía en Valladolid el 15 de julio de 1782. A partir de entonces y en los padrones de aquel municipio de los años 1787, 1797 y 1817 figuran alistados como hidalgos notorios de armas pintar. No obstante la abuela paterna de don Felipe, doña Magdalena Boto, no pertenecía a la nobleza, y en los padrones de 1787 y 1797 está anotada como noble, pero no por derecho originario, sino consorcial o matrimonial. En el interrogatorio de la información de don Felipe para la orden de Carlos III sólo se pedía la cualidad patricia de su padre y madre, y por lo tanto de sus abuelos paterno y materno. A mediados del siglo XVIII, en las respuestas particulares del catastro del marqués de la Ensenada figura Pedro de Sierra, vecino de Villablino, abuelo paterno de don Felipe, como noble. Estaba entonces alistado con el «ejercicio arriero y labrador». Esta última ocupación, como todo empleo agrícola, era considerada compatible con la caballería; más dudosa era la simultaneidad entre la arriería y la condición ecuestre. Sobre la hidalguía de los Sierra Pambley de Laciana hay dos pleitos en la Sala de Hijosdalgo de Valladolid. El primero de ellos fue incoado por Tomás de Sierra, natural del coto de Leitariegos y vecino de Caboalles de Arriba (Laciana), en 1749. Esta causa, a la muerte de Tomás, fue seguida por su viuda, en nombre de sus hijos, y a ella también se incorporó Magdalena Boto, esposa que había sido de Pedro de Sierra, en representación de su hijo Ángel de Sierra. Sin embargo el litigio no pudo terminar peor. Se descubrieron diversas falsificaciones documentales, y semejante fraude impidió que los Sierra se pudieran alistar definitivamente como hidalgos en Laciana. El segundo de los pleitos fue comenzado por Ángel de Sierra en 1777, y en él requirió la copia de otra causa de hidalguía, sustanciada entre 1665 y 1668 por Juan de Sierra, natural del coto de Leitariegos y vecino de Caboalles de Abajo, en la que éste consiguió ser reconocido como noble. En este segundo caso Ángel obtuvo, como se ha dicho, sentencia favorable en 1782. De estos documentos se deduce que los Sierra Pambley de Villablino, apellido éste compuesto que también fue una resurrección 
coto de Leitariegos ${ }^{137}$, bajaron a Villablino, en Laciana, en donde tuvieron su gran oportunidad cuando la desamortización. El itinerario de esta familia en las tierras leonesas describe con gran verosimilitud el relevo del viejo patriciado notorio, cada vez más postrado, por esta nueva aristocracia de profesión mercantil. Entre los bienes que el padre de don Felipe, don Ángel —abastecedor de carnes del cabildo de la ciudad de León en 1805 y administrador de doña Catalina de Cuenllas ${ }^{138}$ _, compró, se cuentan los pertenecientes a

tardía, porque siempre habían sido Sierra a secas, pertenecían a una estirpe muy poco calificada. Aunque, sin prueba documental alguna, se dicen descendientes de los solares de Pambley y su dependiente Onon, ambos en Sierra, alfoz de Cangas de Tineo. La escasa relevancia del linaje y lo poco que ellos mismos sabían de sus ancestros fueron la causa de los percances que padecieron sus deseos de alistarse como hidalgos.

ARCHV, SH, 1253-3. Pleito de hidalguía incoado por Tomás de Sierra, vecino de Caboalles de Arriba (Laciana). (1749-1767); 276-5. Pleito de hidalguía de Angel de Sierra, vecino de Villablino (Laciana). (17771782).

Archivo de la Casa de Carvallo. Cangas del Narcea (Asturias). Documentos de don José Luis Ferreiro Blanco Flórez Valdés, Árbol de la casa de Sierra de Llamas de Mouro. Estudio para un árbol genealógico de la casa de Pambley.

AHN, Estado, Carlos III, exp. 1801, ff. 25-32 vto.: Ejecutoria de nobleza librada por la Real Chancillería de Valladolid a favor de don Ángel de Sierra Pambley. Valladolid, 15 de julio de 1782; ff. 33-35: Diligencia de los padrones de distinción de estados del concejo de Laciana. Rioscuro (Laciana), 16 de junio de 1820.

137 Don Felipe de Sierra Pambley nació en Villablino, de donde eran vecinos sus padres, don Ángel y doña Javiera Fernández Téllez, el 26 de mayo de 1774, siendo bautizado en la iglesia de San Miguel de Laciana el siguiente día 31. Su padre fue acristianado en la misma parroquial el 31 de marzo de 1753, figurando como hijo de don Pedro de Sierra Pambley y doña Magdalena Boto. Este don Pedro nació en el lugar de Brañas del coto de Leitariegos el 29 de junio de 1719, y recibió las aguas bautismales en la parroquial de Santa María de Brañas el 5 de julio siguiente. Eran sus padres Juan de Sierra y María Cosmen. Don Pedro contrajo matrimonio con doña Magdalena en San Miguel de Laciana el 27 de noviembre de 1748; ella era hija de Patricio Boto y de su mujer Josefa Fernández, vecinos de Villablino, en cuya parroquial de San Miguel se la acristianó el 8 de mayo de 1730. AHN, Estado, Carlos III, exp. 1801, ff. 18 vto.-20 vto.: Diligencia en el archivo parroquial de San Miguel de Laciana, 16 de junio de 1820; ff. 59 vto.-61: Diligencia en el archivo parroquial de Santa María de Brañas, del coto de Leitariegos, Santa María de Brañas, 19 de junio de 1820.

138 Don Ángel de Sierra Pambley y Boto fue administrador de doña Catalina de Cuenllas — perteneciente a una ilustre familia con solar en La Cueta de Babia, y al parecer procedente de la casa de Lorenzana-, esposa del mayorazgo y titular vincular de los Gómez de Las Rozas en Laciana. Única hija de este matrimonio fue doña Ana María Gómez de Cuenllas, que contrajo matrimonio en 1786 con don Claudio de Quijada y Quiñones, III marqués de Inicio y IV conde de Rebolledo, hijo de don Luis José de Quijada Quiñones y Moreno, anterior titular de estas mercedes, y de su mujer doña Josefa de Quiñones Álamos. AHN, Consejos, 10024, exp. 10: Instancia de don Luis José de Quijada Quiñones y Moreno, marqués de Inicio y conde de Rebolledo, por la que solicita licencia para que su hijo y de su esposa doña Josefa de Quiñones Álamos, don Claudio, se case con doña Ana María Gómez de Cuenllas. Instancia del Corregidor de León sobre este asunto (26 de agosto de 1786). ARCHV, Pleitos Civiles (PC), Pérez Alonso, Fenecidos, 3762-2: Pleito entre doña Ana María Gómez de Cuenllas, marquesa de Inicio, don Antonio, don Juan y don Pedro de Quijada, vecinos de León, sobre preferencia en el cobro de unas deudas procedentes de los bienes de doña María Antonia López (1829-1830). Ibídem, 3773-5: Pleito entre doña Catalina de Cuenllas, vecina de León, doña Ana María Gómez de Cuenllas, marquesa de Inicio, de la misma vecindad y el monasterio de Nuestra Señora de la Asunción de las Huelgas Reales de Avilés, sobre la propiedad de un prado situado en términos de la Cueta (Babia de Arriba) (1828-1834). Archivo Histórico Provincial de León, Protocolos Notariales, Babia, 6601, s. fol.: Padrón de moneda forera del concejo de Babia de Suso o de Arriba del año 1680. Lugar de Lago: «Diego de Cuenllas escribano del numero deste concejo hijodalgo notorio de cassa y solar conozido 
una de las grandes casas de la tierra, la de los Álvarez del Campillo de Las $\operatorname{Rozas}^{139}$.

Tanto don Felipe como su progenitor fueron eficaces funcionarios en la desamortización anterior a la guerra de la Independencia ${ }^{140}$, con la particularidad de que la familia no sólo aparece como gestora oficial, sino también como adquirente ${ }^{141}$. De esta manera los que habían bajado de los montes al valle de Laciana, con no muchos caudales, también se convirtieron en grandes propietarios. A pesar de su ideología, imitaron los gustos de la vieja nobleza, hasta el punto de colocar arbitrariamente el escudo de los Sierra de Llamas de Mouro en sus casas principales de Villablino ${ }^{142}$. No puede resultar sor-

y armas pintar». Lugar de la Cueta Alta: «Diego de Cuenllas el biexo escribano del numero deste concejo hidalgo notorio de cassa solar conozido y armas pintar. Lope de Cuenllas su ijo de la calidad de su padre. Juan de Cuenllas hidalgo notorio de casa y solar conozido y armas pintar. Josephe de Cuenllas hidalgo notorio de cassa y ssolar conozido y armas pintar [...]. Francisco de Cuenllas escribano del numero deste concejo hidalgo notorio de cassa y solar conozido y armas pintar. Francisco de Cuenllas hijo del dicho Francisco de Cuenllas de la misma calidad que su padre».

En la casa de los Cuenllas del lugar de Lago se encuentra el escudo de esta familia y a su lado esta inscripción: «Armas de la casa de los Diazes y Lorenzanas que tocan a la casa de los Cuenllas por parte paterna. Año de 1690». El solar de este linaje estaba en los términos de La Cueta, según se puede comprobar por una escritura del año 1565. AHPL, Protocolos de Babia, 6807: Carta de pago otorgada por doña Catalina de Prado, vecina de la parroquia de Cibea (Cangas de Narcea, Asturias), viuda de Diego Menéndez de Cangas, madre y tutora de Álvaro, Juan, Luis, Francisco y doña Urraca Flórez y doña Inés y doña Catalina (Lugar de Cuenllas [Babia de Arriba, León], 27 de agosto de 1565). Merino, Los orígenes, s. p.

139 ARCHV, SH, 285-2: Pleito de hidalguía de don José Álvarez del Campillo, vecino de Piedrafita (Babia de Arriba, León) (1817-1820). Diligencia. Villablino (Laciana, León), 13 de octubre de 1818, f. 27-27 vto.: «En el referido dia me constituyi en compañía de dicho procurador en casa de doña Javiera Fernandez Tellez viuda de don Angel de Sierra vecina de Villablino distante medio quarto de legua a quien entere de la real provisión a instancia del don Josef y en su obedecimiento me puso de manifiesto un legajo de escrituras de adquisizion de los vínculos de los Alvarez Campillo de las Rozas [...]»; ff. 29 vto.-30: «Conviene con su original registro que volvió a recoger la doña Jabiera Fernandez Tellez, viuda de don Angel de Sierra y Pambley comprador de el mayorazgo de los Campillos».

140 Merino, Los orígenes, s. p. Cantón Mayo, La Fundación, pág. 28. Carantoña Álvarez, «De la Ilustración», págs. 25-26.

141 Cantón Mayo, La Fundación, pág. 28.

142 En una de las fachadas de las casas principales de los Sierra Pambley en Villablino todavía se conserva el escudo — debajo del cual está inscrito el año 1774—, de excelente factura, de los antiguos dueños del edificio. Los signos heráldicos labrados son los de la casa de Llamas de Mouro, en el concejo de Cangas del Narcea, cuyo apellido común era el de Sierra, aunque también utilizaron el de Sierra Osorio. Sin embargo, si se admite que el tronco del linaje es el de los Sierra Pambley, como aparentemente se deduce de los pleitos de hidalguía ya señalados, no son estas señales las que le corresponden, sino las de la casa de Pambley, también en el citado concejo asturiano, que son distintas. El solar de Pambley tiene diverso origen, a lo que se conoce, del de Llamas, y también del de Jarceley, éste presumiblemente una rama de los Alfonso de Llano. Tanto los vástagos de la matriz de Pambley como los de la de Jarceley, ambos en el partido de Sierra, lo mismo que la de Llamas, se apellidaron comúnmente con el toponímico de Sierra, por la situación donde se encontraban, y en numerosas ocasiones añadían el del lugar en que estaban ubicados los solares, Pambley o Jarceley. El causante, o al menos el que contribuyó a consolidar este error, fue el cronista rey de armas don Pascual Antonio de la Rua Ruiz de Naveda que, con fecha 1 de octubre de 1782, firmó una carta de armas en que las describe así: «Campo de plata y en él castillo negro con llamas que le abrasan, y a su puerta un hombre 


\section{prendente que el último señor de este solar, don Francisco Fernández Blanco}

de Sierra Pambley, quisiera devolver a la humanidad el fruto de tan tortuosas maniobras $^{143}$.

armado de espada y rodela, impidiendo su entrada, viéndose en la punta del escudo una barca con tres remos sobre ondas azules y de plata». Este escudo, que figura como una variedad del de Sierra de Llamas de Mouro, no es exactamente idéntico al de la citada casa de Villablino.

En las casas lacianiegas se pintó el blasón de los Sierra de Llamas de Mouro, en vez del de los Pambley, que es, al parecer, el que verdaderamente les correspondía. Esto confirma lo que ya está dicho, que los Sierra Pambley de Villablino carecían de tradición nobiliaria alguna y que este ahidalgamiento tardío responde a su vanidad familiar, carente de precedentes suficientemente informados. Fue una manera de dorar su acceso a la clase de propietarios con blasones propios del Antiguo Régimen. Se ve que querían sobresalir por todos los conceptos posibles. No está de más decir que el escudo como signo distintivo no supone el disfrute de la nobleza, pues también podía ser utilizado por los plebeyos. Lo que resultaba común en el Antiguo Régimen es que las señales heráldicas, en su forma nobiliaria, solían ser empleadas por los patricios más eminentes. La mayor parte de los nobles asturleoneses no los utilizaban, sin que por ello estuviera menoscabada su calidad. En suma el escudo, más que una señal de hidalguía, tenía sólo un valor inicial o conjetural, era una muestra en el estamento de cierta superioridad económica, social y política.

El escudo de los Sierra de Llamas de Mouro y de los Pambley de este lugar: Meléndez de Arvas, Prosapias, págs. 129, 130, 131 y 147. Cantón Mayo, La fundación, pág. 26. Bernabé Moreno de Vargas, Discursos de la nobleza de España, Madrid, 1636, ed. facs. 1977, ff. 108 vto.-111, discurso Xix. Manuel Caballero, Noticias documentales y genealógicas de las Asturias de Tineo, Tineo, 1995, págs. 75 y 98-102. Martín DE RiqueR, Heráldica castellana en tiempos de los Reyes Católicos, Barcelona, 1986, págs. 19-24. Francisco Sarandeses, Heráldica de los apellidos asturianos, Oviedo, 1966, ed. facs. 1994, págs. 271-272 y 338-339; escudos núms. 1128-1133 y 1490-1500. Alfonso de Ceballos-Escalera y Gila, marqués de la Floresta, Heraldos y reyes de armas en la corte de España, Madrid, 1993, pág. 252.

143 Como ya se ha dicho, los Sierra Pambley adquirieron bienes desamortizados en tiempos de Carlos IV. Volvieron a hacerlo durante el Trienio Liberal, por lo que tuvieron, al restaurarse los poderes íntegros de Fernando VII, que devolverlos. En 1835 les fueron restituidos, al menos en parte. En las operaciones desamortizadoras durante el reinado de Isabel II, de nuevo se les ve como compradores. De todo esto se deduce que una parte muy considerable del patrimonio tuvo su origen en estas iniciativas. No es necesario insistir en las irregularidades que se cometieron en ellas y en el grave daño que produjeron al común de la población, y sobre todo a su parte menos heredada, por el nulo sentido social con que se realizaron. De todas maneras, parece que la mentalidad de esta familia, antes de la actividad filantrópica de don Francisco Fernández Blanco de Sierra Pambley, era de un clasismo riguroso. Como reconoce Carantoña, basado en un informe de don Felipe de Sierra Pambley de septiembre de 1802, éste se opone a los derechos de los llevadores de los bienes raíces, tal como los había reconocido la legislación ilustrada, por lo que su postura perjudicaba al campesinado. Su propia actitud ante los revoltosos que el 28 de marzo de 1808 se manifestaron en León ante su casa, festejando la caída de Godoy y protestando contra la venta de los bienes de las obras pías, demuestra a las claras su desdén por las clases populares. Parece que entonces tiró por la ventana una hogaza de pan, como para dar de comer al hambriento.

Si se tiene en cuenta la propiedad inmueble que a mediados del siglo XVIII poseían tanto los Fernández Blanco (en torno a 4,86 hectáreas), como los Sierra Pambley (aproximadamente 6,35 hectáreas), se puede deducir con toda evidencia el notable enriquecimiento que les produjo la desamortización. Por todo ello, la esplendidez dadivosa de don Francisco pudo ser el desenlace reparador de unas adquisiciones de discutible moralidad, bajo la forma del rigorismo ético, de cierto sabor jansenizante y de una religiosidad despersonalizada, característica del generoso benefactor. AHPL, Catastro del marqués de la Ensenada, caja 8915, núm. 1161: Autos obrados por don Gaspar Antonio de La Vandera y Ponze de Leon, subdelegado para las diligencias de la unica contribucion en este concejo de Laciana, 9 de septiembre de 1752, ff. 20 vto.-29 vto.: Bienes de Pedro de Sierra, vecino de Villablino. Cantón Mayo, La Fundación, págs. 28 y 55-56. Aguado Cabezas, «Segundo Sierra Pambley», pág. 210. CARantoÑa Álvarez, «De la Ilustración», págs. 26, 28 y 56. 
No es posible ignorar este enrarecido ambiente a la hora de estudiar las prácticas desamortizadoras, y por lo tanto dejar de situarlas en las circunstancias en las que se realizaron. Todo ello explica el lógico y popular aborrecimiento que causaron, sentimiento que no sólo nació de una divergencia ideológica en materia político-económica, sino también de un juicio moral. Habida cuenta, por ende, el clima en que se desenvolvió la desamortización de Godoy es comprensible que Canga Argüelles se apresurara a sacar provecho de circunstancia tan favorable. En la tasación de Lindes no se valoró la jurisdicción «por considerarla de ninguna utilidad; pero sí en siete ducados los siete corderos que pagaban los vecinos del coto por razón de vasallaje». La documentación del XIX asegura que el señorío no sólo comprendía derechos de naturaleza pública, sino que también poseía la calidad de solariego, en donde residía su verdadero valor ${ }^{144}$.

\section{Y, por fin, señor de los de verdad}

La conversión de Canga Argüelles en señor de vasallos se produjo al tiempo del declive trágico de aquel remedo de monarquía tradicional que era la realeza borbónica en España. El efervescente descontento que propició la abdicación de Carlos IV y que puso sus esperanzas en el hasta entonces heredero del trono, ahora Fernando VII, poseía una alta dosis de condena de la desamortización.

Las masas populares reaccionaron irasciblemente ante los propugnadores de una política cuyo tono burgués y ejecución dolosa había sacrificado los intereses de una beneficencia estrafalaria. Éste es un aspecto que no se puede soslayar, ni incluso aunque el historiador quiera encapsularse en una mera formalidad jurídica o estudio institucional. Se trata de una primera manifestación del disfraz progresista con que a lo largo del siglo XIX se embozó el liberalismo para servir las pretensiones de unos pocos. Resulta evidente que los sucesos del año 1808 fueron popular y masivamente una réplica a la línea política seguida en el reinado que entonces fenecía. Los más notoriamente identificados con las corrientes renovadoras hubieron de atravesar tiempos de zozobra. El común de la sociedad podía ser todo lo inculto e inerte que se quiera - la especie de un pueblo tiranizado por la nobleza y fanatizado por el clero no es cierta-, pero no era tan estúpido que dejara de darse cuenta de la dirección que hasta entonces se impulsaba desde el gobierno de la nación y desde las élites ilustradas. De alguna manera vislumbró el clasismo que se estaba preparando desde el poder y que se conseguiría establecer a raíz del triunfo liberal. Y en este cambio, el cuerpo

144 Canella Secades, «Quirós», págs. 454-455. 
social no iba a resultar beneficiado, sino todo lo contrario. La sospecha sobre la probidad económica de los gestores públicos no era un juicio temerario, y estaba relacionado con una idea que con el tiempo se haría realidad: la formación de una clase social que fuera el sostén del nuevo orden ${ }^{145}$. Es evidente que muchos, no todos, prohombres ilustrados antes de 1808 ya eran liberales, aunque hasta entonces no explayaran al completo sus ideas por la sujeción que imponía el sistema monárquico. No es creíble que en ellos, de la noche a la mañana, creciera la planta del constitucionalismo como una generación exótica y sorprendente.

Los que en los tumultuosos sucesos de los años 1808 a 1814 se distinguieron por sus ideas constitucionales podían caer bajo la sospecha de cierta conducta poco patriota, cuando no abiertamente traicionera. Si a esto se une el sesgo económico, parcialmente esbozado por la Ilustración, se puede encontrar la clave razonable de la aversión social a los cambios radicales. Aquellas minorías ilustradas, o más o menos liberales, quedaban estigmatizadas por la doble acusación de la infidencia y el fraude.

Resulta lógico que don José Canga Argüelles, e incluso su padre, sufrieran en los primeros tiempos de la Francesada serios ataques sobre su patriotismo o su probidad económica. El primero de ellos, desde su intendencia de Valencia el 15 de noviembre de 1809, se ve obligado a elevar a la Junta Central una expresiva instancia, con toda la retórica grandilocuente propia de los nuevos tiempos, defendiéndose a sí mismo y a su padre ${ }^{146}$. El acusador fue, en este caso, don José Antonio de la Cerda y Marín de Resende, conde de Contamina ${ }^{147}$, por

145 Es más interesante estudiar la desamortización civil y eclesiástica desde el punto de vista práctico y de sus consecuencias que en su vertiente legal y jurídica. El mero estudio formal no ofrece la visión veraz de la operación. Aunque hubo formulaciones sobre que su ejecución se hiciera de tal modo que favoreciera a las clases más modestas, la verdad es que, y con toda intencionalidad, se llevó a la práctica fomentado mayores diferencias económicas en la sociedad. En efecto, una cosa fue la teoría y otra la realidad. No es por eso sorprendente que el común de la población mostrara su disconformidad con ella y se mantuviera al margen — se orilló y lo orillaron- del sistema liberal que la llevó a cabo. Resulta lógico que, frente al principio de sufragio universal masculino establecido por la Constitución de 1812, la revolución terminara por defender criterios restringidos. A lo largo de todo el reinado de Isabel II, ni los moderados ni los progresistas, pese a algunas proclamas, se atrevieron a imponerlo. El aspecto económico tuvo una estrecha conexión con el político. En ambas realidades se impuso una solución desafortunada, bajo la apariencia sofística del progreso, y que fue la causa de la intrincada trayectoria española. La institución que más perdió, materialmente, fue la Iglesia, cuyo patrimonio fue enajenado con escaso provecho social. La exclaustración de los regulares, medida necesaria para nacionalizar sus bienes, se hizo con las miras de crear una clase social que fuera fervorosamente liberal. Cfr. Manuel Revuelta González, La exclaustración (1833-1840), Madrid, Edica, 1976.

146 Véase el apéndice documental IV.

147 Se trata del VII conde de Contamina, nacido en Valencia el 29 de abril de 1771 y muerto en la misma ciudad el 26 de julio de 1825. Por entonces todavía no era conde de Parcent, sería el sexto titular de esta merced a la muerte de su padre. Pertenecía a una familia de grandes. Sus progenitores se llamaban don José María de la Cerda y Cernesio, V conde de Parcent (Madrid, 23 de abril de 1747-Madrid, 17 de septiembre de 1811), y doña María del Carmen Marín de Resende Francia y Fernández de Heredia, V condesa de 
medio de una representación del 28 de octubre anterior. Los cargos que hacía al caballero asturiano eran muy graves, entre ellos los de malversación de caudales públicos y afición a innovaciones. Don Felipe era consejero de Castilla, y como ya se sabe este alto organismo se había mostrado en exceso condescendiente con los franceses ${ }^{148}$. Era entonces su decano otro asturiano, don Arias de Mon y Velarde Prada, que después de plegarse a las exigencias extranjeras terminaría por declararse patriota, lo que le valió el destierro y la muerte en París $^{149}$. El supremo consejo estaba aferrado a un formal juridicismo — claro legado de la ilustración dieciochesca- y, con titubeos y reconocimientos muy poco honorables, sobrevivió como pudo a la coacción de las autoridades napoleónicas, pero no pudo librarse del desprestigio ${ }^{150}$. Es perfectamente explicable

Bureta († Valencia, 25 de febrero de 1784). Habían contraído matrimonio en la iglesia de San Miguel de los Navarros de Zaragoza el 17 de noviembre de 1768.

El VII conde de Contamina el 28 de diciembre de 1793 se casó en Madrid con doña María Ramona de Palafox y Portocarrero, hija de don Felipe de Palafox y Croy (San Sebastián, 3 de enero de 1739-Madrid, 24 de octubre de 1790) y de su mujer doña María Francisca de Sales Portocarrero y Fernández de Córdoba (Madrid, 10 de abril de 1754-Logroño, 15 de abril de 1808), la ilustrada y famosa condesa de Montijo. Era por lo tanto hermana del VIII conde de Montijo, don Eugenio, que tanto figuró durante la guerra de la Independencia.

148 AHN, Consejos, 5525, exp. 2: Expediente sobre la comunicación que se hizo al Consejo de Castilla sobre la propuesta hecha por el emperador Napoleón I a favor de su hermano mayor José, rey de Nápoles, para la Corona de España (copia: Madrid, 18 de julio de 1808). Consulta del Consejo, 13-14 de mayo de 1808: «Lo que deseaba el Consejo para manifestar de algún modo su profundo reconocimiento, y no hallaba términos con que conciliar su obediencia con lo que exige la ley que no pende de su afeccion ni de su arbitrio. Pero ya que esta ha de quedar ilesa por parte del Consejo según dicha real orden y que conforme a su letra han de quedar asi mismo preservados los derechos a la succesion de esta Corona de los señores don Carlos Quarto y su hijo el principe de Asturias con los demas a quienes pueda pertenecer, desde luego le parece que en execucion de lo resuelto por su majestad ymperial podría recaer la elección para rey de las Españas en Josef Napoleon rey de Napoles; pues aunque el Consejo no tiene el honor de conocerle sabe su soberana condecoración y que siendo hermano mayor del emperador de los franceses y rey de Ytalia y habiéndose grangeado por sus altas y generosas prendas su singular estimación, no puede menos de estar adornado de sus mismas virtudes, actividad y talentos. Esta oportuna reflexión la ha visto el Consejo calificada en este dia por las noticias uniformes que se le han proporcionado de sujetos políticos que no pueden ignorarlas. No quisiera sin embargo agraviar con esta preferencia a las demas personas ymperiales y reales de esta augusta familia pues a todas las considera mui dignas y acredoras: por cuya razón sugeta el Consejo su opinión a las superiores luces y grandes conocimientos del emperador de los franceses y rey de Ytalia a cuio superior discernimiento experiencia y dotes para gobernar ymperios y hacer feliz a la humanidad, no intenta de modo alguno alcanzar el Consejo. Madrid y mayo catorce de mil ochocientos y ocho». En estas circunstancias uno de los consejeros que asistió a estas proposiciones y consultas fue, según aparece en los documentos, don Felipe Canga Argüelles.

149 Javier PÉREz DE RADA, Relación de los poseedores del castro y palacio de Priaranza del Bierzo de alguno de sus allegados y descendencia de ellos, Madrid, 1999, pág. 202. AHN, OM, Calatrava, mod. 72: Pruebas de don Fernando de Mon Velarde Prada y Argüelles Quiñones (1814), ff. 38 vto.-42 vto.: Discernimiento de la tutela y curaduría de los hijos de don Arias de Mon Velarde Prada, a favor de la viuda de éste doña María del Rosario de Argüelles Quiñones y Velarde Prada. San Martín de Oscos, casa principal de Mon (San Martín de Oscos), 4 de julio de 1812. En esta escritura se afirma cómo el decano del Consejo de Castilla falleció en París el 1 de enero de 1811. Cfr. AHN, OM, Expedientillos, 12569 y 18983: Pruebas de don Fernando de Mon Velarde Prada y Argüelles Quiñones para la orden de Calatrava (1814-1815).

150 Artola, La España, págs. 71-76. 
que se sospechara de la fidelidad de don Felipe. Y esta reserva debió subsistir con peligrosa persistencia en aquellos años confusos. En 1813 su viuda, doña Paula de Cifuentes Prada, pediría la certificación sobre que había pertenecido a la Junta de Defensa de Madrid ${ }^{151}$, constituida el 1 de diciembre de 1808 para proteger la capital del ataque del mismo Napoleón ${ }^{152}$, y que por lo tanto tras notorias vacilaciones se había comportado heroicamente.

En lo que no debía ser don José sincero — en su defensa de 1808 frente al conde de Contamina-, era cuando afirmaba su inmovilismo político. Aunque, acusado de ansia de mando y de gusto por las novedades, replique que «fundo toda mi vanidad en que Fernando VII me encuentre quando vuelva a España del mismo modo que me ha dexado», resulta indudable que no iba a ser así.

Poco después, ya siendo ministro de Hacienda, fue de nuevo acusado de poca limpieza administrativa; en este caso se le atribuían ciertas irregularidades en materia económica a favor de su amigo don Vicente Beltrán de Lis ${ }^{153}$.

Convertido don José en un flamante señor de vasallos, pasó a formar parte de la élite nobiliaria, aunque fuera en términos bien exiguos. Muy poco después el Estatuto de Bayona y los decretos promulgados por Napoleón, tras su

151 Véase apéndice documental v.

152 AHN, Consejos, 5526, exp. 5: «Nota. Hoy primero de diciembre de 1808 estando el Consejo pleno compuesto de los señores del margen, se trató lo conveniente que sería crear una junta militar y política que con motivo de las críticas circunstancias en que se halla la Corte acordase las providencias convenientes a las urgencias que ocurrian, y que a este fin fuese permanente: y en su virtud proveyó el decreto siguiente:

Madrid primero de diciembre de 1808.

Se crea una junta compuesta del capitan general de esta provincia, del teniente general don Tomas de Morla, del gobernador de la plaza y del de la Sala de Alcaldes, del corregidor de Madrid, del yntendente de exercito, de los generales y oficiales del exercito, de quatro ministros del Consejo, de otros tantos regidores de esta villa que elijan el señor presidente del Consejo y los tenientes generales marques de Castelar y don Tomas de Morla y del ministro mas antiguo de todos los demas consejos a cuya Junta presidida del señor presidente del Consejo se comete todo el gobierno politico y militar de Madrid, deviendo ser permanente para el mas cabal desempeño de sus funciones. Publiquese su establecimiento y pasense los avisos competentes. [Rubricado]

A consecuencia de esta providencia acordó el Consejo que la Junta se formase en la casa de Correos por ser el sitio mas a proposito por estar en el centro del pueblo y con este obgeto se paso a los directores generales de Correos el oficio de que se acompaña minuta.

Ademas de los señores nombrados en este decreto nombro su excelencia por lo tocante al consejo a los señores ministros Vilches, Lardizabal, Canga y Moyano, y la Junta al señor conde de Montarco, don José Justo Salcedo, a los tres señores ynspectores generales de caballeria infanteria y milicias, al señor conde de Montijo, principe de Castelfranco, y don Bartolome Tobar y tambien concurrieron a ella los señores decanos de los demas consejos a consecuencia de los oficios que en el mismo instante se les paso por su excelencia el señor decano [Rubricado]».

La resistencia de Madrid fue poco más que testimonial, falta de medios militares y cercada por el ejercito más poderoso de Europa. El día 4 de diciembre las tropas francesas, previa capitulación, ocuparon la Corte. Artola, La España, pág. 139.

153 Fonseca Cuevas, Un hacendista, pág. 48. 
entrada en Madrid, el 4 de diciembre de 1808 abolían los derechos feudales ${ }^{154}$. Las Cortes de Cádiz los días 3 y 4 de agosto de 1811 aprobaban la supresión del régimen señorial en sus aspectos jurisdiccionales y derechos monopolísticos y proclamaban el respeto a las facultades solariegas y territoriales, bajo el rótulo de la propiedad. La Regencia lo promulgó por decreto de 6 de agosto siguiente $^{155}$. Sin embargo la transitoria eficacia de las providencias revolucionarias, a partir del retorno de Fernando VII en 1814, dejó la cuestión señorial en una situación ecléctica. Ahora, por real cédula de 9 de agosto de 1814 se declararon extintas las prerrogativas de derecho público y las monopolísticas y se mantuvieron las facultades solariegas, según su antigua terminología ${ }^{156}$. Este extremo permitirá al antiguo ministro, pese a la persecución de que fue objeto por sus ínfulas liberales, seguir titulándose señor de Lindes. La reacción de 1814 le había costado la prisión en Madrid. La sentencia definitiva de su proceso, con fecha 18 de agosto de 1815, lo condenó a ocho años de presidio en el castillo de Peñíscola, a la pérdida de la mitad de su sueldo y a la inhabilitación ${ }^{157}$. Sus derechos con respecto a Lindes no los perdió, pues consta que en el año 1816 todavía nombraba alcalde del $\operatorname{coto}^{158}$.

Restablecido el texto constitucional gaditano el 7 de marzo de 1820, Canga Argüelles, una vez recobrada la libertad, vuelve a ser uno de los prohombres de la España liberal ${ }^{159}$ y a la vez continua en la titularidad del coto. En este tiempo se da una curiosa circunstancia: el dueño de Lindes es un prohombre liberal y, por eso, no es extraño que don Pedro Bernaldo de Quirós, señor del mayorazgo de la torre y casa de Ronzón, el descendiente vincular de los antiguos y despojados señores, sobresalga como uno de los más acérrimos absolutistas de Asturias ${ }^{160}$. Eventualidad que vuelve a ser realmente paradójica, sobre todo por cuanto de nuevo se pone en vigor el decreto de 6 de agosto de 1813. Una ley de 3 de mayo de 1823 pretendió solucionar los aspectos más espinosos en la aplicación de aquél ${ }^{161}$.

154 Moxó, La disolución, pág. 16.

155 Artola, La España, págs. 374-379. Moxó, La disolución, pág. 13. Rafael García Ormaechea, Estudios de la legislación y jurisprudencia sobre señoríos, Sangüesa (Navarra), 2002, págs. 5-29.

156 Moxó, La disolución, págs. 81-97.

157 Fonseca Cuevas, Un hacendista, pág. 93.

158 Canella Secades, «Quirós», pág. 455.

159 El 22 de marzo de 1820 fue designado ministro de Hacienda, oficio en el que cesó por exoneración regia el 2 de marzo de 1821. El 3 de diciembre de 1821 fue proclamado diputado por Asturias para las cortes de 1822-1823. Fonseca Cuevas, Un hacendista, págs. 52-57 y 63-66. Artola, La España, págs. 531-532 y 555. José Manuel Cuenca y Soledad Miranda, El poder y sus hombres. ¿Por quiénes hemos sido gobernados los españoles? (1705-1998), Madrid, 1998, pág. 425.

160 Carantoña Álvarez, Revolución liberal y crisis de las instituciones tradicionales asturianas, Gijón, 1989, pág. 266.

161 Moxó, La disolución, págs. 99-136. García Ormaechea, Estudio, págs. 30-38. 
De esta época hay un curioso documento, del año 1821, en el que el representante y gestor de don José otorga la sustitución de su poder, en virtud de una escritura firmada por éste en Peñíscola en 1817, en donde se titula «Del Consejo de Su Majestad, secretario con exercicio de decretos, ministro juvilado de capa y espada de el Consejo Supremo de Yndias, cavallero de la real y distinguida orden española de Carlos Tercero, señor de el coto y lugar de Lindes, patrono de su yglesia ${ }^{162}{ }_{»}$. La ostentación en pleno periodo constitucional de esta última titularidad, procedente de una antiquísima concesión señorial, no podía dejar de aparecer como un contrasentido. Pero ya entonces un sector del liberalismo se iba inclinando cada vez más hacia posturas en extremo conservadoras, en las que el orden público y la paz civil se habrían de sustentar sobre la clase de propietarios. La operación, que le resultó muy beneficiosa, incluyó la transformación de derechos señoriales en facultades dominicales de índole privada. En muchos casos fue un auténtico fraude, pero resultó el único modo para que un sector importante de la nobleza no se fuera al realismo primero, y al carlismo después.

Aunque hay muy pocos datos de la conducta de Canga Argüelles como señor de Lindes, las noticias aseguran que fue un administrador diligente: restauró la vieja iglesia parroquial de Santo Tomás, concedió viviendas y otras ventajas a los colonos y a los que se quisieran establecer en el remoto lugar y suscribió arriendos por nueve años. Dice Canella que éstos eran favorabílisimos, y que el prócer entonces manifestó sentimientos benéficos, y en todo fundado en principios sólidos de la Economía ${ }^{163}$.

Vuelto Fernando VII en 1823 a recuperar la plenitud de la soberanía, se torna a declarar, por real cédula de 15 de agosto de aquel año, subsistentes las facultades solariegas de los antiguos señores, que sin embargo no se ven reintegrados en los derechos públicos y exclusivos ${ }^{164}$. Lo que pudiera quedar de peculiaridad en Lindes tenía por lo tanto los días contados. La audiencia de Asturias pidió a Fernando VII que las demarcaciones señoriales de la provincia se unieran al concejo más próximo. Por real orden de 18 de diciembre de 1826 se ordenó que a partir del último día de dicho año todos los lugares particulares se anejaran a efectos de la administración y justicia, sin perjuicio del arreglo general, al municipio inmediato. En su virtud el Real Acuerdo incorporó el coto de Lindes al concejo de Quirós ${ }^{165}$.

162 Véase apéndice documental VI.

163 Canella Secades, «Quirós», pág. 455.

164 Moxó, La disolución, págs. 139-144.

165 Matías Sangrador y Vitores, Historia de la administración de justicia y del antiguo gobierno del Principado de Asturias y colección de sus fueros, cartas pueblas y antiguas ordenanzas, Oviedo, 1866, ed. facs. Capellades, Barcelona, 1989, págs. 278-279. 
A pesar de que ya Lindes dejó definitivamente de ser en sentido estricto un coto, el cambio no supuso una gran novedad para sus dueños. Permanecieron subsistentes los derechos que se consideraron privados, quedando subsumidos en las prerrogativas de la propiedad. De esta forma el linaje perseveró como el propietario por excelencia en la antigua jurisdicción.

La trayectoria de la estirpe desde que el exiliado don José, a partir de los últimos años del reinado de Fernando VII, adoptó la decisión de desandar los pasos que había dado contra la monarquía absoluta ${ }^{166}$, estuvo dirigida a incorporarse, en pleno derecho, a la alta sociedad del momento ${ }^{167}$. Con Isabel II, el 10 de diciembre de 1852, vendría la merced del condado de Canga-Argüelles, concedido al hijo del hacendista don Felipe Canga Argüelles y Ventades ${ }^{168}$, y su inclusión en la derecha dinástica, actitud que adoptó con notorio conservadurismo y especial profesión de religiosidad ${ }^{169}$. El II conde, don José María Canga Argüelles y Villalba, terminaría por pasarse al carlismo ${ }^{170}$ y fue uno de sus próceres más notables durante la época de Carlos VII ${ }^{171}$. Pero esta mudanza dinástica no fue consecuencia del convencimiento, sino del pavor ante una revolución, como la de 1868, que se les figuraba más atroz que cuantas hasta entonces habían acaecido. Las relaciones de los Canga Argüelles con la segunda familia de la reina gobernadora doña María Cristina de Borbón Dos Sicilias —típico

166 Al menos desde 1828 se observa en sus escritos, estando exiliado en Inglaterra, una mudanza radical. Defiende a Carlos IV y a Fernando VII, elogia a la Iglesia y se arrepiente de las exaltaciones políticas de antaño. Fonseca Cuevas, Un hacendista, págs. 109-116.

167 Aunque los autores no se ponen de acuerdo sobre cuándo volvió a España, Fonseca Cuevas se inclina a que el retorno ocurrió por el año de 1833, pues el 24 de octubre de 1833 don Francisco Zea Bermúdez signó la licencia de su repatriación. Durante el reinado de Isabel II, apartado de las luchas políticas, fue un alto funcionario de la Administración Central. Falleció en Madrid el 2 de diciembre de 1842. FonseCa Cuevas, Un hacendista, págs. 66-69, 117 y 143.

168 AHN, Consejos, Cancillería, Registro del Sello de Corte, 8984, año 1852, exp. 618: Real despacho por el que se concede la merced del titulo de conde de Canga Argüelles a don Felipe Canga Argüelles y Ventades (Madrid, 10 de diciembre de 1852). Cfr. AHN, Estado, 6319, exp. 37: Expediente sobre el nombramiento de caballero de la orden de Isabel la Católica a favor de don Felipe Canga Argüelles, oficial primero de la Sección de Aranceles en la Secretaría de la Dirección General de Rentas (1835); 6335, exp. 4: Nombramiento de caballero gran cruz de la orden de Isabel la Católica a favor de don Felipe Canga Argüelles, director de Fincas del Estado hecho el 28 de febrero de 1848 con fecha 1 de enero anterior (Madrid, 17 de enero de 1848). Fonseca Cuevas, Un hacendista, pág. 28, n. 29.

169 El I conde de Canga Argüelles ingresó en 1852 en la Real Academia de la Historia con un discurso titulado «Influencia de los institutos religiosos en los adelantos de la historia». Fonseca Cuevas, Un hacendista, pág. 28.

170 La desbandada casi general de los monárquicos isabelinos al campo de Carlos VII se recoge con vivos sentimientos en Antonio dE URbina, marqués de Rozalejo, Cheste o todo un siglo (1809-1906). El isabelino tradicionalista, Santander, 1939, págs. 229-248. El II conde figura como vocal, a principios de 1869 , de la Junta Central católico-monárquica que presidió el marqués de Villadarías, éste de una estirpe carlista de vieja ejecutoria.

171 En 1854 don José María Canga Argüelles fue diputado a las Cortes Constituyentes por el tradicionalismo representando al distrito de Burgo de Osma. Fonseca Cuevas, Un hacendista, pág. 29. 
hogar moderado- siempre habían sido muy cordiales ${ }^{172}$. Por eso, tras el paso de las violencias de la revolución, volvieron al redil conservador, eso sí, en las posiciones más circunspectas que pudieron ${ }^{173}$. Esta profesión política se anudaría cuando don Joaquín y doña Ana, hijos del II conde de Canga Argüelles, casaron en 1886 y 1890 con los también hermanos doña Eladia y don Fernando Muñoz y Bernaldo de Quirós, III duque de Riansares, nietos de la gobernadora ${ }^{174}$. Casi parece que las pillerías ilustradas y liberales de antaño habían sido, o una locura fruto de la inexperiencia y del idealismo destemplado, o una rocambolesca obra de la vanidad y la ambición. Y al fin, aquel último cambio —el paso al tradicionalismo - se puede explicar como un signo del miedo, del arrepentimiento y de la expiación, ante el desastre de la España liberal.

\section{Apéndices documentales}

Respuestas generales sobre el coto de Lindes, incluso en el concejo de Quirós, en Asturias.

Lindes (Quirós, Asturias), 22 de julio de 1752.

AGS. Respuestas generales. Catastro de Ensenada, ff. 601-606.

[f. 601] Coto de Lindes incluso en el concejo de Quirós.

Copia de las respuestas generales.

Respuestas generales.

En el coto y jurisdicion de Lindes a veynte y dos dias del mes de jullio de mil setezientos cinquenta y dos, concurrieron en la casa de Posada el señor don Diego Bruno Rivera subdelegado de dicho coto, y en el conzejo de Quiros y tres

172 AHN, Diversos, Títulos, Familias, 3406, leg. 133, exp. 2; 3414, leg. 150, exp. 1; 3428, leg. 190, exp. 1; 3439, leg. 221, exp. 1; 3544, leg. 8, exp. 44; 3545, leg. 9, exp. 12; 3562, leg. 26, exp. 22; 3564, leg. 28, exp. 26; 3568, leg. 32, exp. 1; 3570, leg. 34, exp. 12; 3575, leg. 43, exp. 3; 3576, leg. 44, exp. 12. (18471870). En estos legajos se contiene correspondencia muy interesante de los Canga Argüelles.

173 En la Restauración canovista los Canga Argüelles figuran en la Unión Católica de los Pidal, que terminaría por servir para que muchos católicos se incorporaran a la derecha conservadora y liberal.

174 Doña Eladia (Somió, 22 de marzo de 1863-Madrid, 3 de junio de 1933) y don Fernando (Somio, 2 de marzo de 1864-Madrid, 20 de marzo de 1913), III duque de Riansares, hijos de don Fernando Muñoz y Borbón (Madrid, 27 de abril de 1838-Somió, 7 de diciembre de 1910) y de su esposa doña Eladia Bernaldo de Quirós y González de Cienfuegos (Oviedo, 18 de febrero de 1839-Gijón, 31 de marzo de 1909), de la casa de los marqueses de Camposagrado, se casaron respectivamente el 1 de mayo de 1886 y el 30 de enero de 1890 con don Joaquín († junio de 1887) y doña Ana (Madrid, 26 de febrero de 1868-Madrid, 20 de julio de 1917), hijos de don José Canga Argüelles y Villalba, II conde de Canga Argüelles, y de su esposa doña Joaquina López Dóriga y Bustamante. 
sexmos que llaman de Arriva y en su presenzia y ante mi el presente escribano el señor Juan Fernandez juez por el estado noble en dicho coto don Diego Horbiz cura parrocho de el; Francisco Rodriguez Cienfuegos escribano de numero y ayuntamiento del referido concejo Juan Gonzalez y Juan Sanchez Peritos nombrados por dicho juez y a todos los expresados a excepcion de dicho parrocho dicho señor subdelegado por ante mi el escribano de la operazion recivio juramento que le hicieron por Dios nuestro Señor y una señal de cruz en forma, y vajo de el prometieron decir verdad de lo que supieren y les fuere preguntado, según han alcanzado en lo que reconocieron, y vieron y siendoles [f. 601 vto.] leido el ynterrogatorio de la Real Instrucción señalado con la letra A a cada una de sus preguntas depusieron lo siguiente.

[Al margen: $\left.1 .{ }^{a}\right]$ A la primera que este dicho coto se nomina Lindes el que es dependiente si solo sin que tenga union con coto ni conzejo alguno y que en quanto a rentas reales lebas y quintas de soldados, no paga cosa alguna.

[Al margen: 2. ${ }^{\mathrm{a}}$ ] A la segunda que dicho coto es de señorio: y que pertenece a los Reales Hospitales de la Colegizial de Santa Maria la Real de Arbas del Puerto en el Reyno de Leon, no saviendo por que motivo; y que por razon de señorio paga cada uno de sus vezinos y en cada un año un cordero al abad de dicha colegial y administrador de dichos Reales Hospitales.

[Al margen: $\left.3{ }^{a}\right]$ A la terzera que el termino de dicho coto ocupa dos leguas de lebante a poniente y otras dos menos quarto de norte al sur: y cinco y media de circunferenzia que se podran andar en catorce oras por lo aspero y montañoso del terreno sus linderos, y confrontazion por el oeste conzejo de Lena [f. 602] y sitio que llaman el Cueto de Mallada Vieja. Mediodia conzejo de Quiros y sitio que dicen la Cueva de Valseco. Poniente dicho concejo y hoio del Cuchillar de Rueda desde donde corta por la loma que llaman de las Tennas al norte por el que confronta con dicho concejo de Quiros y desde aquí sigue al sitio que dicen Lende la Gallina y Vega de Espinas en donde cierra el ovalo su figura la del marjen [al margen el dibujo].

[Al margen: 4..$\left.^{\mathrm{a}}\right]$ A la quarta que en el termino de dicho coto hay las especies de tierra de secano siguientes y ninguna de regadio:

[Al margen: $\left.1 .{ }^{\mathrm{a}}\right]$ Tierras de labor de dar pan una: $\mathrm{y}$ al siguiente abas negras.

[Al margen: 2. ${ }^{a}$ Prados de guadaña son de dar yerva y pazion de otoño o solo yerva.

[Al margen: $\left.3 .^{\mathrm{a}}\right]$ Tierra inculta en abertal que sirve de pasto a los ganados.

[Al margen: 4. $\left.{ }^{a}\right]$ Tierra inculta por naturaleza de montes de ayas espinos riscos peñas peladas y maleza que no producen utilidad alguna.

Y se nota que no hay tierra alguna en el termino que produzca mas que una cosecha al año, ni tampoco con año de intermedio y el producir de año 
en año seguidamente consiste en el continuo abono con que los venefician sus labradores.

[f. 602 vto.] [Al margen: 5. ${ }^{\text {a] }}$ A la quinta que en las dos especies de tierra primeras que han declarado hay las calidades de buena media y en las demas solo la ynfima.

[Al margen: 6. $\left.{ }^{\mathrm{a}}\right]$ A la sexta que no hay plantio alguno de arboles frutales en las tierras que han declarado.

[Al margen: $7 .^{\mathrm{a}}$ y $\left.8 .^{\mathrm{a}}\right]$ A la septima y octava que se remiten a lo que tienen declarado en la antecedente.

[Al margen: 9. ${ }^{a}$ ] A la novena que la medida de tierra que se usa en dicho coto es por dias de bueyes que es la que esta dada generalmente por la Justicia y regimiento de la ciudad de Oviedo y se ussa en la maior parte de este Principado la que se compone de veinte y quatro baras claberas de frente y quarenta y ocho de costado o largo, teniendo cada una de estas varas, cinco quartas castellanas con que viene a componerse el frente de cada dia de bueyes de treynta varas castellanas, y sesenta de largo y en el termino que ocupa un dia de bueyes de la citada medida se siembran quatro copinos de pan de escanda y el año siguiente otros quatro de abas negras siempre alternatibamente en todas las calidades.

Y se nota que cada fanega de dicho coto se compone de dos celeminos que hazen seis copinos y medio por la fanega de la ciudad de Oviedo, y trece zeleminos castellanos.

[f. 603] [Al margen: 10] A la dezima que en el termino de dicho coto hay como cosa de onze mil nuevecientos y ochenta y un dia de bueyes en esta forma: sesenta y cinco de tierras de labor, seis de buena calidad. Doze de mediana y quarenta y siete de ynfima, ciento y noventa y tres de prados y segadios. Veynte de baja calidad treynta y uno de mediana y ciento quarenta y dos de ynfima. Dos mil dias de bueyes de pastos para los ganados merinos y nuebe mil setezientos veynte y tres al cumplimiento del total inporte de tierra ynculta por naturaleza de montes y peñas, sin que de ello percivan utilidad alguna y en quanto al medio de medidas que se piden al fin de la pregunta de cada una de las especies que se siembran en dicho termino se remiten a las respuestas quarta y nona que antezeden.

[Al margen: 11] A la once que en el termino de dicho coto solo se cogen las especies de frutos que se refieren en la respuesta quarta.

[Al margen: 12] A la doce que la medida de un dia de bueyes sembrado con quatro copinos de pan en tierra de buena calidad produce con ordinaria cultura y veneficio unos años con otros dos fanegas de pan en el de mediana una y media y en el de ynfima una. Y el dia de bueyes que al siguiente año se siembra de abas negras (pues nunca sembrarse maiz en dicho coto respecto de no ser a 
proposito el terreno para esta semilla) produce en tierra de [f. 603 vto.] buena calidad dos fanegas y en la de mediana una y en la de ynfima media. El dia de bueyes de prado de buena calidad produce quatro corzas de yerba que hacen un carro y pazion de otoño el de mediana de un carro con la misma pacion, y el de ynfima medio carro con la misma pacion de otoño a excepcion de quarenta dias de bueyes que quitado el primer pelo quedan en avertal de esta calidad.

[Al margen: 13] A la trece que no hay nada de lo que contiene.

[Al margen: 14] A la catorce que el valor que ordinariamente tiene la fanega de pan de escanda es el de diez y ocho rreales vellon la de abas negras que se compone tambien de doce copinos por la referida medida de este coto a nueve reales el carro de yerba lo mismo y la entrada o suerte correspondiente a su terreno de pacion de otoño la estiman en tres rreales siendo de buena calidad en dos la de mediana y en uno la de ynfima y el que produce para merinas en veinte y quatro maravedis y un quarto de otro.

[Al margen: 15] A la quince que sobre las tierras y heredades de dicho coto solo se halla ympuesto el derecho de diezmo que es de diez uno y el de primicia que es un copin de pan cada vezino y que perteneze uno y otro solo al parrocho.

[Al margen: 16] A la diez y seis que el derecho de diezmo y primicia en el referido coto $[f$. 604] suele montar un año con otro a quatro fanegas de pan el de primizia a siete copinos y el de abas negras a quatro fanegas todo por la referida medida. De manteca diez libras, de lana tres, componiendose cada libra de veinte y quatro onzas; de miel y zera quatro rreales de ganados maiores y menores como son terneros corderos cabritos, y tocino que por otro nombre llaman abenencia veynte y dos rreales.

[Al margen: 17] A la diez y siete que no hay alguno de los artefactos que contiene.

[Al margen: 18] A la diez y ocho que en el termino de dicho coto hay esquilmo de leche de bacas, terneros, y terneras, potrancos, borregos, cabritos, zerdos, miel zera, y manteca: y que no hay esquileo alguno pues que cada vezino esquila en su casa. Y que de aquellos esquilmos se regula la utilidad para sus dueños en este modo: a cada baca un quartillo de leche al dia, manteniendo su ternero, y como las bacas regularmente estan un año de cria, y leche, y el otro no, se reputa por medio quartillo de leche cada dia, no perciviendo maravedies algunos por ello el vecindario respecto no haver costumbre en dicho coto de benderse; y necesitarlo para el gasto de sus casas, y por lo mismo regulan el esquilmo de cada baca y en cada un año en quatro libras de manteca a dos reales cada libra; [f. 604 vto.] y que en esta consideracion regulan a cada ternero mientras mama en treynta y dos reales, considerandose asi unas bacas lecheras 
con mas que no lo son tanto; y unos y otros terneros buenos con malos a un potranco mientras mama en quarenta y quatro reales y una potranca en sesenta y como las bacas, y yeguas regularmente paren de dos en dos años, biene a quedar el esquilmo de cada baca en diez y seis reales cada año exclusa la manteca. Y el de cada yegua teniendo potranco en veynte y dos reales y con potranca en treynta, y que pertenece a sus dueños tenederos, y aparceros según que cada uno lo expresara en su relacion. A cada borrego quatro reales regulandose a cada caveza mayor de ovejuno media libra anualmente de esquileo y a real cada libra. A un cabrito tres reales: a un zerdo de cria quatro: regulando a cada zerda que este parida tres mamones, a uno de matanza treynta y tres reales. Y por lo que mira al esquilmo de cada cubo de abejas, o colmena bien atendida el estilo del pais que es matar las que tiene el cubo para aprovecharse de dicho esquilmo lo que hacen de tres en tres años por ser preciso este tiempo para que [f. 605] produzcan nuebos enjambres consideran la cera y miel de cada cubo de abejas quando las matan en seis reales que corresponde dos en cada un año. Y en quanto al numero de ganados que hay en el termino de dicho coto propio de vecinos se reduce a veynte y ocho bacas veinte y ocho terneros y terneras diez y nuebe novillos, y novillas quatro bueyes: una yegua, un potro, sesenta ovejas, treynta y dos corderos; quatro carneros, diez y seis cabras; ocho cabritos; dos zerdas paridiegas; quatro guarros y diez y ocho para la proxima matanza. Y de ganados de forasteros recivido en aparceria por los vecinos de dicho coto se reduce su numero a veynte y una bacas, diez y ocho terneros y terneras, trece novillos, y novillas, un buey, un potro, quatro cabras, dos cabritos, y una zerda para criar, y dado en aparzeria fuera del coto, una baca y un ternero, y regulan un par de bueyes de labranza en veynte y quatro ducados.

[Al margen: 19] A la diez y nueve que en dicho coto hay veynte colmenas: tres Juan Fernandez; quatro Francisco Gonzalez; y trece Luisa Fernandez.

[Al margen: 20] A la veynte que en dicho coto hay cinco especies de ganado que son cavallar, bacuno, lanar, cabrio y de zerda y que ningun vezino [f. 605 vto.] tiene cavaña, revaño, yeguada, ni bacada alguna.

[Al margen: 21] A la veynte y una que en dicho coto hay el numero de siete vecinos en que se incluye una viuda.

[Al margen: 22] A la veynte y dos que hay quatro casas abiertas y una arruinada, y que ningun vecino paga en particular cosa alguna a dicho abad por razon del suelo.

[Al margen: 23] A la veynte y tres que dicho coto tiene de propios las yerbas de los puertos llamados Vallin y Rueda que se hallan dentro de sus terminos y pastan en ellos mil setecientos y veynte y una cavezas de ganados merinos del real monasterio de San Lorenzo del Escorial cuio producto absciende en cada 
un año a mil setezientos veynte y un reales vellon según andan arrendados los referidos pastos y pertenece a dichos Reales Hospitales de dicha colegial quien los percive.

[Al margen: 24 asta 34] A la veynte y quatro hasta la treynta y quatro inclusive que no hay nada de lo que contienen.

[Al margen: 35] A la treynta y cinco que en dicho coto hay travajadores del campo maiores de diez y ocho años y que para los labores que se ofrecen a sus vecinos se llaman y ayudan unos a otros sin mas ynteres que la comida pero si no tuvieran entre si esta correspondenzia [f. 606] buscarian jornaleros y en este caso se pagaria un real a cada uno y la comida regulando esta en otro real por lo que se considera cada jornal de hombre que travaja en el campo en dos reales cada dia.

[Al margen: 36 y 37] A la treynta y seis, y treynta y siete que no hay nada de lo que contienen.

[Al margen: 38] A la treynta y ocho que en dicho coto no hay mas clerigo que el parrocho.

[Al margen: 39 y 40] A la treynta y nueve y quarenta en que consiste el real ynterrogatorio que no hay cosa alguna de lo que contienen.

Y despues de concluidas dichas quarenta preguntas de que se compone el real ynterrogatorio de letra A se leio todo lo en ellas contenido y puesto por todos los declarantes quienes dijeron a una voz no tenian que añadir ni quitar y que por lo mismo se afirmavan y ratificavan en dicho declarado so cargo del juramento que hicieron y lo firmaron los que supieron junto con dicho señor subdelegado y por los que dijeron no saber un testigo que lo fue Melchor Suarez vezino de la parrochia de Cienfuegos Diego Antonio de Rivera = Melchor Suarez $=$ Francisco Rodriguez Cienfuegos $=$ Ante mi $=$ Antonio Bernardo .

[Firmado: Saavedra]

[Firmado: Francisco de Alvares]

Respuestas generales sobre la villa de Santa María de Arbas del Puerto (León).

Santa María de Arbas del Puerto (León), 14 de julio de 1753.

AGS. Respuestas generales. Catastro de Ensenada, ff. 133-139 vto.

[f. 133] Copia de respuestas generales de la villa de Santa Maria de Arbas del Puerto. 
En la villa de Santa Maria de Arbas del Puerto a catorce dias del mes de julio de mil setecientos cinquenta y tres su merced el señor lizenciado don Juan de Valcarze abogado de los Reales Consejos juez subdelegado por su majestad (Dios le guarde) para las diligencias en que debe fundarse la unica contribucion estando en su compañía el señor doctor don Santiago de Robles Castañon colegial maior de San Yldefonso de Alcala abad perpetuo de esta real colegiata; don Alonso de la Vega Ravanal prior y canonigo de ella, y Thoribio Gutierrez residente en esta villa, y de este su [f. 133 vto.] merced por ante mi el escribano recivio juramento que le hizo por el nombre de Dios nuestro señor y una señal de cruz en forma, y siendo preguntado por el real ynterrogatorio a cada una de sus preguntas dijeron lo siguiente.

[Al margen: $1 .^{\mathrm{a}}$ ] A la primera que esta villa se llama la villa de Santa Maria de el Puerto.

[Al margen: 2. ${ }^{a}$ A la segunda que es realengo, y con pribativa jurisdicion reservandose la dignidad abacial para si la autoridad de justicia por no haver yndibiduo lego a quien poner sin que por esta razon tenga mas renta ni efecto que la correspondiente a su dignidad.

[Al margen: 3. $\left.{ }^{\mathrm{a}}\right]$ A la tercera que el terreno propio de esta villa ocupa desde el oriente al poniente media legua larga, de norte a mediodia tres quartos de legua, y de circunferencia dos [f. 134] leguas y media, linda al oriente termino de el lugar de Vega que lo es suio pesquisurio y jurisdicion [al margen un dibujo de los límites del término de Santa María de Arbas] poniente termino de San Miguel de el Rio, y camino que llaman de Pandoto, norte termino de Pajares y de el concejo de Lena, y mediodia termino de el lugar de Viadangos su figura la de el margen.

[Al margen: $\left.4{ }^{a}\right]$ A la quarta que en este terreno solo ay algunos prados regadios, y secanos de un pelo solo de guadaña cadañeros y algunos secanos de otoño, puertos de pasto para ganados, finos, y campos publicos para otros ganados y monte de aya y roble de mediano cuerpo en que tienen el derecho de cortar sus maderas los vecinos del referido lugar de San Miguel de el Rio y todos los de el conzejo de la Tercia ay [f. $134 \mathrm{vto}$.] tambien hortaliza de secano.

[Al margen: 5. ${ }^{\mathrm{a}}$ A la quinta que en los prados de guadaña ay de buena mediana y ynfima calidad, como tambien en los de ganados finos, y los prados otoñeros secanos y huertos de hortaliza son de unica calidad.

[Al margen: $\left.6 .^{a}\right]$ A la sexta que no ay arbol frucifero alguno ni demas especies que los referidos.

[Al margen: 7. $\left.^{\mathrm{a}}\right]$ A la septima que estos estan en montes ondos, aguas vertientes al Principado de Asturias.

[Al margen: 8. ${ }^{a}$ A la octava que no tienen mas formalidad que el arvitrio de la naturaleza formando una espesura de bastante considerazion. 
[Al margen: 9. ${ }^{\mathrm{a}}$ ] A la novena que para recurir los granos de qualquiera especie que sean la medida de que ordinariamente [f. 135] se usa la que llaman emina compuesta de quatro celemines castellanos, que tres de estas hacen una fanega, y doze una carga, y no se responde mas a su contenido.

[Al margen: 10. ${ }^{a}$ ] A la diez que no se puede asegurar las eminas de campo que ay de cada expecie en este terreno por lo que se remiten al reconocimiento echo por el agrimensor, perito y su acompañado.

[Al margen: 11] A la onze que solo se coje yerva.

[Al margen: 12] A la doze que cada hemina de prado de buena calidad produce problablemente dos forcados de yerva, uno y medio la de mediana, y uno la de ynfima, y en quanto a las eminas de puerto no aseguran quanto puede utilizar cada emina sin embargo de que los ganaderos tienen [f. 135 vto.] el arbitrio de pastarlo todo porque lo mas dello no es provechoso para aquel ganado. En cuio supuesto solo se refiere el util general que se ynfiere de las escripturas de arriendo y cada emina de hortaliza doze reales de producto anual; y los prados secanos tres reales por el otoño cada año.

[Al margen: 13] A la trece que de los arboles no se saca utilidad alguna aquí.

[Al margen: 14] A la catorce que cada forcado de yerba vale siete reales regularmente.

[Al margen: 15] A la quince que de nada se paga diezmo alguno por que todos los efectos de el terreno se distribuien en la mesa capitular y no se paga primicia ni voto de Santiago.

[Al margen: 16] A la diez y seis no tienen que responder.

[Al margen: 17] A la diez y siete que ay un molino en el casco de esta poblacion arinero [f. 136] de una muela que muele con agua del arroyo de los Pozos, este es propio del real hospital de esta villa y atendiendo a que solo muele en las crecientes del ynbierno utiliza cada año dos fanegas y media de trigo; tambien tiene otro dicho hospital en la raya que divide el termino de Vega Lamosa que muele con agua del mismo arroio y por que esta desmejorado, ay poco pan que moler solo utiliza ocho reales cada año tambien ay otro que llaman rio de Murias propio de Manuel Tascon vecino de Vega Lamosa, y atendiendo a que tambien muele muy poco tiempo por el rigor de el tiempo y falta de granos utiliza cada un año otros ocho reales, y no ay otro artefacto alguno.

[Al margen: 18] A la diez y ocho que no ay casa [f. 136 vto.] de esquileo destinada.

[Al margen: 19] A la diez y nueve que no ay colmena alguna.

[Al margen: 20] A la veinte que ay bueies, vacas, ovejas, carneros, yeguas, y algun cavallo de carga, y cada vaca considerando la alternatiba de su parto 
utiliza al año diez y seis reales cada oveja que pare por el cordero cinco reales y uno por una libra de lana, cada carnero por el vellon que se regula en dos libras de lana dos reales, cada yegua que unas veces se sirve de el contrario, y otras del natural, utiliza cada año consideradas las contigencias de su parto cinquenta reales cada año; el valor ordinario de los bueies que le tienen igual que las vacas es a cien reales cada uno y de ninguna expecie ay cavaña dentro ni fuera de el termino.

[Al margen: 21] A la veinte y una que no ay [f. 137] vecino alguno lego y solo un abitante que asiste al hospital y los familiares que tiene el señor abad y canonigos.

[Al margen: 22] A la veinte y dos que ay trece casas abitables y ninguna arruinada y no se paga nada por su establecimiento.

[Al margen: 23] A la veinte y tres que esta villa y su real colegiata percive anualmente de el Puerto que compone la piedra y los pozos mil y doscientos reales por los ganados finos que en ellos pagan de la cavaña de Guadalupe por el ganado que pasta de la excelentisima casa de Alburquerque en Vallemadera y Ofellina mil reales cada año; cuios efectos se concedieron perpetuamente por los monarcas antecesores y en expecial por el santo rey don Fernando para efecto de que con maior comodidad se pudiese conservar el culto [f. $137 \mathrm{vto}$.] divino en esta real colegiata; y es cierto que estos ni los demas efectos aplicados a este fin superabundan porque aunque todos los predios y rentas que se distribuien a cada canonigo se beneficien o arrienden con el maior cuidado no asciende su producto a mil y quatrocientos reales cada año, y de esto se ha de mantener con los seglares de su asistencia.

[Al margen: 24] A la veinte y quatro que no disfruta otro arvitrio aunque en terrenos forasteros tiene la comunidad otros efectos de que se ha dado razon pero con todos y su distribuzion no tiene mas renta que la referida.

[Al margen: 25] A la veinte y cinco que de comunidad se satisfacen los derechos de utensilio y no otra cosa.

[Al margen: 26] A la veinte y seis que la comunidad [f. 138] tiene mil ducados de censo contra si a favor de la dignidad abacial que se saco para litigar un pleito con la villa de Pajares por defender el derecho de un pedazo de terreno que les querian usurpar.

[Al margen: 27] A la veinte y siete que no se paga servicio real.

[Al margen: 28] A la veinte y ocho que no se pagan alcavalas.

[Al margen: 29] A la veinte y nueve que no ay taberna ni otro abasto alguno.

[Al margen: 30] A la treinta que ay un hospital real que sirve para el socorro de qualquiera persona transeunte de qualquiera calidad que sea con la precisa pension de dar a cada uno tres libras de pan de trigo cada dia si permaneciese, 
y si estubiese enfermo asistirle a proporcion [f. 138 vto.] todo el tiempo que estubiese, y si el transeunte fuese de distincion o necesitado, de maior edad se le socorre ademas de el pan con un par de huebos y un quartillo de vino, y sopa a todos en general con cama prevenida cuios gastos se conservan con las rentas que les tiene concedidas los monarcas a este fin en diversos lugares de que se ha dado relazion: tambien ay otro refugio, y casa como de hospital aguas vertientes a Asturias que sirve para lo mismo de recoger los pasajeros aunque no se distribuie cosa alguna.

[Al margen: 31$]$ A la treinta y una que no ay cambista ni mercader.

[Al margen: 32] A la treinta y dos que no ay nada de su contenido.

[f. 139] [Al margen: 33] A la treinta y tres que no ay ofizial alguno de su contenido.

[Al margen: 34] A la treinta y quatro que no ay nada de su contenido.

[Al margen: 35] A la treinta y cino que no ay jornalero alguno y los labradores ganan de jornal quatro reales al dia de su trabajo.

[Al margen: 36] A la treinta y seis que no ay pobre de solemnidad alguno.

[Al margen: 37] A la treinta y siete que no ay persona alguna que tenga trafico en el mar.

[Al margen: 38] A la treinta y ocho que esta real colegiata de compone de un señor abad que es caveza puesto por su majestad (Dios le guarde) un prior, thesorero, chantre y otras mueve plazas de canonigos todos sacerdotes, cuias vacantes propuestas por la dignidad abacial confirma su majestad.

[Al margen: 39] A la treinta y nueve no ay mas convento de religion.

[Al margen: 40] A la quarenta que a su majestad (Dios le guarde) no se le contribuie con finca de alguna circunstancia.

Esto dijeron y declaro dicho Toribio Gutierrez so cargo de el juramento fecho en que se afirmaron ratificaron y firmolo dicho señor abad y prior con su merced y en fee de ello lo firme = Lizenciado don Juan de Valcarzel = Don Santiago de Robles $=$ Don Alonso de la Vega Ravanal $=$ Ante mi Francisco Antonio Sanchez .

[Firmado: Guiralde]

[Firmado: Francisco de Alvarez]

Partida de bautismo de don José Canga Argüelles y Cifuentes Prada.

Oviedo, 11 de septiembre de 1771.

APSIO. Libro de bautismos núm. 11 (1770-1781), f. 30 vto. 
[Al margen: Jose Antonio Pio] En la yglesia parroquial de San Ysidoro el Real de esta ciudad de Oviedo a onze dias del mes de julio año de mil setezientos setenta y uno, yo el ynfra escripto teniente bautize solennemente y puse los santos oleos a un niño que dixeron habia nazido el mismo dia, y se le puso nombre Joseph Antonio Pio, hixo lexitimo del doctor don Phelipe Ignazio Canga Argüelles, bautizado en San Tirso el Real de esta ciudad, y de doña Antonia Paula Cifuentes Prada bautizada en la villa de Jixon, fueron padrinos don Joseph Antonio Canga Argüelles y doña Maria Francisca Fernandez Mieres, la qual no toco ambos abuelos del referido niño, adbertile las obligaciones y cognazion, y en fe de lo dicho lo firmo.

[Firmado: Jazinto Antonio Garcia]

Exposición de don José Canga Argüelles, contador principal del reino y ejército de Valencia, a la Junta Suprema Central Gubernativa del Reino.

Valencia, 15 de noviembre de 1809.

AHN. Estado, 47, D.

Señor

Don Jose Canga Argüelles contador principal de este exercito y reyno encargado de la yntendencia del mismo en todos sus ramos hace presente a vuestra majestad que han llegado a esta ciudad varios traslados de la representacion que con fecha de 25 de octubre proximo hizo a vuestra majestad el excelentisimo señor conde de Contamina, en la qual se le acusa de poco patriotismo; se me atribuye parte en la mala versacion de los caudales del rey, se supone que mi anciano y desgraciado padre ocupa un puesto eminente en la Corte del intruso rey; y se pretende hacerme autor de las desavenencias que dice han ocurrido en este reyno.

Seria un delinquente contra la patria contra el honor y contra los respetos devidos a los destinos que ocupo por la bondad del rey nuestro señor y de vuestra majestad si divulgadas en esa ciudad y en esta unas especies tan denigrativas a mi conducta me mantuviera pasivo. Ynmediatamente que tuve noticia de ellas acudi a esta Junta Superior de Observacion pidiéndole permiso para separarme de ella y de la Comision de la Yntendencia que vuestra majestad me ha confiado exigiendo que se me formase la causa correspondiente, y poniendo mi persona a disposición del Gobierno: mas la Junta por oficio de 10 del corriente me contexto en los términos siguientes. 
«La Junta Superior de Observacion y Defensa de este reyno ha leído con dolorosa atención el oficio de vuestra señoria de ayer y la copia de la representación del señor conde de Contamina hecha a su majestad en la que entre otras cosas acusa a vuestra señoria de poco patriota y de mal administrador de las rentas de su majestad. La separación que vuestra señoria pide a la Junta del Cargo de la Yntendencia y de asistir a las sesiones de la misma es efecto de la delicadeza de vuestra señoria de su honor y de sus principios; pero la junta que esta altamente convencida de los patrióticos sentimientos de vuestra señoria y que ha visto con el mayor agrado los grandes esfuerzos y el sagrado ardor con que vuestra señoria se ha conducido en los asuntos que ha tenido a su cargo no puede consentirlo. La Junta pues que lleva acordado ya los pasos que debe dar en desagravio de vuestra señoria quiere que vuestra señoria continue al frente de los negocios de la Real Hacienda como hasta ahora y que asista vuestra señoria también a sus sesiones pues no la queda duda de que en ambos destinos necesita la patria del zelo integridad expedición y conocimientos de vuestra señoria.»

El honor propiedad sagrada del hombre que la indemniza de los derechos que perdió al constituir las sociedades, es imprescriptible e inenagenable y esta libre de toda dependencia: defenderle es un deber, asi como dejar que se pierda es abandonar la halaja mas preciosa. Por ello me disculpara vuestra majestad el que le moleste con esta reverente representación dirigida a vindicar mi honor por los medios que la ley señala y que sabiamente se han substituido a los que en los siglos de nuestras glorias había introducido el pundonor de los nobles para repeler los ataques individuales.

La patria, señor, no puede exigir de sus hijos sacrificios de honor que envilenciendolos los haría perder aquel carácter firme y decidido sin el qual ni hay sociedad, ni hay patria, ni se pueden emprender las grandes acciones que conducen el Estado al colmo del poder. El abatimiento desgraciado con que en los días del ultimo reynado hemos visto mancillar nuestro honor y nuestro decoro, nos llevo a la triste situación en que nos miramos: pero vuestra majestad substituyendo el imperio de la razón al de la arbitrariedad y del embilecimiento en su augusta instalación nos ha ofrecido «que mandaria la voz sola de la ley fundada en la utilidad general», y esta voz de la ley es la que me lleva a los reales pies de vuestra majestad.

Hago la justicia al señor conde de Contamina de creer que una idea equivocada nacida de siniestros informes dados por algunos sujetos de torcida intencion le habrá obligado a acusarle de un modo tan terrible. Porque si no, ¿cómo pudiera caber en la nobleza de su cuna el que se ensangrentare tan cruelmente contra un sujeto que ni por injurias ni por beneficios le esta unido? ¿Contra mi 
que en la eleccion para diputado tube el gusto de darle mi voto? ¿Cómo pudiera caber en su fina educacion y en la liberalidad de sus principios el dirigir sus tiros contra mi anciano padre? ¿ $\mathrm{Ni}$ como era posible que el señor conde hubiese callado quando la Suprema Junta a mi regreso de Madrid me declaró buen patriota y me confió el despacho de los negocios de la yntendencia y solo trate de acusarme de trahicion y de faccioso, quando la Junta Superior de Valencia usando de los derechos que cree asistirle ha nombrado vocal que la reemplace en la Central?

El patriotismo del señor conde es demasiado notorio para que hubiese dexado sepultadas en el silencio unas noticias que tanto podian conducir al bien de la patria. Por ello repito que informes malos y siniestros le habran hecho creer que soy delincuente: por ello el vindicarme es un deber de que no puedo dispensarme para convencimiento del señor conde para el de vuestra majestad, para el de este reyno y para mi tranquilidad.

Se dice que «soy hijo de un padre que ocupa un puesto eminente al lado del intruso rey». Esta es la primera noticia que he tenido de ello: y siento en el alma que no se me hubiese anticipado porque entonces hubiera visto vuestra majestad que se preferir el amor de la patria a el de mi padre; mas con documentos probaré que lejos de ocupar un puesto eminente, vive en la obscuridad y en la pobreza porque no sufraga ya para su manutencion el rendimiento de las fincas que me pertenecen en Madrid y le he dexado para el efecto, y que si reside en Madrid es porque sus achaques y ancianidad le impiden la salida sobre lo qual he representado a vuestra majestad por el Ministerio de Gracia y Justicia con fecha de 26 de marzo ultimo: ¡terrible situacion la mia de tener que sujetar a pruebas la conducta de un padre que se ha envejecido en el servicio del rey que se ha dado siempre a conocer por su patriotismo y por la entereza de su carácter!

Pero supongamos que ocupase un puesto eminente al lado del intruso rey: demos por cierto que por debilidad, por miedo, o por malicia se hubiese agregado a este partido (sobre cuyo particular juro por lo mas sagrado que ninguna idea tengo), ¿esto acaso puede influir sobre mi? Vuestra majestad tiene dicho lo contrario en la contestacion dada al conde de Someruelos y en su caso tendria vuestra majestad que separar de los exercitos a algunos que se distinguen en ellos por su valor y patriotismo.

Me acusa de autor de las desavenencias ocurridas en Valencia. Ni estas me son conocidas ni mi vida enteramente entregada al trabajo me dexa tiempo libre para dedicarme a las intrigas ni a confabulaciones precisas para el caso y agenas de mis ideas. Mi conducta es harto publica, y nadie dirá que se me halle en otra parte que en mi despacho o entre los negocios: por consiguiente no puedo 
dar otra respuesta a una imputacion que en la generalidad con que viene concebida lleva su desvanecimiento.

Añade que aun quando me anime el zelo mas patriotico mi ambicion de mando y los medios de que me valgo para lograrlo son subersibos.

Debe saber el señor conde porque lo sabe Valencia que si mi corazon acobijara la noble o vil pasion del mando la pudiera haber esplicado en las circunstancias terribles en que se ha visto el pueblo. Por el contrario con documentos irrefragables acreditare a vuestra majestad y a la nacion mi desprendimiento y mi moderacion: tengo documentos y testigos que depondrán sobre la resistencia que hize quando por la salida de este reyno de don Francisco Xavier de Azpiroz se me encargo la yntendencia: vuestra majestad sabe que no he pretendido la comision de ella y que la he renunciado por representación de 10 de mayo próximo: tengo en Sevilla y en esta ciudad sujetos que atestiguaran la repugnancia con que la tome y los deseos que he manifestado y manifiesto de dejarla; y los mismos podrán decir si he usado de intrigas ni de pretensiones quando la elección de diputados en la Central en el año próximo pasado en la qual solo dos votos la decidieron entre mi y el excelentisimo señor principe Pio. He fundado y fundo toda mi voluntad en que Fernando $7 .^{\circ}$ me encuentre quando vuelva a España del mismo modo que me ha dexado; y esta idea la manifeste desde el principio de la Santa Rebolucion y la procuro acreditar con los hechos.

Continua el señor conde que para obtener y conservar el mando me valgo de medios subersivos y antipoliticos solo buenos para dividir los animos. Desde que vuestra majestad se digno confiarme esta yntendencia en comision no he omitido diligencia medio ni arbitrio para mantener el sagrado entusiasmo en favor de la patria hallar fondos para atender a las urgencias del erario y para acallar los gritos de la necesidad desatendida saliéndome para ello de proclamas circulares exitaciones de que a su tiempo presentare exemplares; vuestra majestad la ha visto; vuestra majestad ha aprobado mis operaciones de un modo demasiado lisonjero, y esta es la mas cabal respuesta que puedo dar: nadie podrá probar que orden alguna dimanada de vuestra majestad no haya recibido el mas puntual cumplimiento por mi parte. Asi no entiendo sobre que puede recaer la tacha de subversión a no dar este nombre a la firmeza de mi carácter al respeto que profeso a las leyes a la eficacia con que procuro su observancia al desinteres con que me conduzco y al fuego que me anima por la libertad de mi patria.

Finalmente me atribuye el señor conde afición a innovaciones harto publica y notoria. Si por innovaciones entiende el deseo de que los negocios caminen por las reglas que la razón prescribe, siempre he sido amigo de ellas. Lo fui en efecto porque nadie se atrevió antes que yo a resistir las violentas pretensio- 
nes de la Francia: nadie oso luchar contra los agravios que recibimos en ella; y tengo la gloria infructuosa, pero que prueba mi amor al rey y a la nacion de haber procurado apartar al engañado Carlos $4 .^{\circ}$ del abismo en que le precipito su demasiado candor y condescencia, de lo qual tengo datos que presentare a vuestra majestad y al mundo: y a quien ha manifestado desde los primeros pasos de su carrera tanto amor a su patria y a su rey ¿sera justo que se le quiera hacer pasar como faccioso y como traydor ante vuestra majestad que es lo mismo que denunciarme como tal ante la nacion? Vuestra majestad no podrá consentir que queden sin justificación unos dichos tan negros; ni yo puedo menos de suplicar a vuestra majestad se sirva mandar se me forme causa y reciban las correspondientes justificaciones, no para pedir contra quien me acusa porque le considero engañado por falsos informes sino para que mis ideas queden descubiertas.

Si vuestra majestad se digna admitirme al mismo tiempo la dimisión del encargo de la yntendencia; la suspensión del empleo de contador que obtengo por gracia del señor don Carlos $4 .^{\circ}$ confirmada por el señor don Fernando, y la separación de la Junta Superior mientras me sincero, consultara vuestra majestad a mi decoro y a mis principios, y dara vuestra majestad satisfacción al publico con quien me debo considerar por sospechoso.

Siempre que el señor conde de Contamina en vista de mi causa quede convencido de mi hombría de bien de mis ideas distantes de mando y de facciones quedare satisfecho para con el: pero señor mi opinión y mi honor no son solamente mios, son de mis hijos, son de mis coetáneos, y de la nación entera; me costo trabajo adquirir la primera y he debido a Dios el segundo: sin embargo resignado siempre en la voluntad de vuestra majestad me conformare con la providencia que tuviere a bien acordar en el caso, que siempre será la mas acertada y la mas conforme a justicia.

Dios guarde a vuestra majestad muchos años. Valencia 15 de noviembre de 1809.

Señor

A los reales pies de vuestra majestad.

Orden de don Joaquín García Domenech, jefe político, en comisión nombrado por la Regencia del Reino, de la provincia de Madrid, a don Bartolomé Muñoz de Torres, secretario de su majestad de cámara más antiguo y de gobierno que fue del extinguido Consejo de Castilla, a instancia de doña Paula de Cifuentes Prada, viuda de don Felipe Canga Argüelles, ministro del extinguido 
Consejo de Castilla, para que certifique que el finado había formado parte de la Junta de Defensa de Madrid en 1808.

Certificación del citado don Bartolomé Muñoz de Torres, sobre la pertenencia de don Felipe Canga Argüelles a la Junta de Defensa de Madrid en 1808.

Madrid, 30 de septiembre-1 de octubre de 1813.

AHN. Consejos, 5526, exp. 5.

[Al margen: fecha en $1 .^{\circ}$ de octubre] Doña Paula Cifuentes de Prada, viuda del señor don Felipe Ygnacio Canga Argüelles, ministro que fue del extinguido Consejo de Castilla, me ha expuesto, necesita hacer constar en la Tesoreria Nacional, que el referido su difunto marido fue uno de los individuos nombrados para la Junta se estableció de orden superior, para la defensa de esta capital, cuyo nombramiento se halla en la Escribania de Gobierno del mismo Consejo del cargo de vuestra señoría. En su vista he acordado, que vuestra señoria se sirba dar a la expresada doña Paula, certificacion de lo que constare sobre dicho particular.

Dios guarde a vuestra señoria muchos años. Madrid 30 de septiembre de 1813.

[Firmado: Joaquin Garcia Domenech]

Señor don Bartolome Muñoz de Torres.

Don Bartolome Muñoz de Torres secretario de su majestad de camara mas antiguo y de gobierno que fue del extinguido Consejo de Castilla.

Certifico que con motibo de las circunstancias urgentisimas y perentorias, que motibaron la entrada de las tropas francesas en las inmediaciones de esta villa, el referido Consejo en pleno celebrado en $1 .^{\circ}$ de diziembre de 1808 acordó crear una junta compuesta del capitan general de esta provincia: del theniente general don Thomas de Morla: del governador de la plaza y del de la Sala de Alcaldes: del corregidor de Madrid: del yntendente de exercito: de los generales y oficiales del exercito: de quatro ministros del [tachadura] mismo Consejo: de otros tantos rejidores de esta villa que elijiesen el señor presidente del Consejo y los thenientes generales marques de Castelar y don Thomas de Morla; y del ministro mas antiguo de todos los demas consejos; a cuya Junta presidida del señor presidente del Consejo se cometio todo el Gobierno politico y militar de Madrid, deviendo su permanencia para el mas cabal desempeño de sus funziones y que se publicase como se publico su establecimiento. Y de los quatro señores [Al margen, [tachado: uno de los quatro] señores ministros del Consejo] [tachado: ministros] [entre lineas y tachado: del Consejo] elejidos por su excelencia el señor presidente para la citada Junta fue [entre lineas: uno] el señor 
don Phelipe Ygnacio Canga [tachado: como uno de los ministros de el] [entre lineas: mismo Consejo]. Y para que conste a instancia de la señora doña Paula Cifuentes de Prada viuda de dicho señor Phelipe Canga y en virtud de esta providencia lo firmo en Madrid a 1. ${ }^{\circ}$ de octubre de 1813.

Escritura de poder para litigar otorgada por don José Coello, contador del Crédito Publico de la provincia de Asturias, en nombre de don José Canga Argüelles, del Consejo de su majestad, caballero de la orden de Carlos III y señor del coto de Lindes, a favor de don Bernardo González Alberú, procurador de la Audiencia Territorial de dicha provincia.

Oviedo, 27 de noviembre de 1821.

AHA. Protocolos de Oviedo, 8545. Protocolo del año 1821. Escribano Pedro Álvarez, ff. 289-292.

En la ciudad de Oviedo a veinte y siete dias del mes de nobiembre de mil ochocientos veinte y uno ante mi escribano y testigos don Jose Coello contador de el Credito Publico de esta provincia dijo. Que por don Jose Canga Argüelles se otorgo el poder que con substitucion es de el tenor siguiente: Sepase por esta carta publica como yo don Jose Canga Argüelles de el Consejo de su majestad secretario con egercicio de decretos ministro juvilado de capa y espada de el Consejo Supremo de las Yndias cavallero de la real y distinguida orden española de Carlos Tercero señor del coto y lugar de Lines, patrono de su yglesia, residente en esta ciudad y plaza de Peñiscola otorgo: que doy todo mi poder cumplido lleno y bastante qual de derecho se requiere, y es necesario a don Jose Cancio oficial segundo de Contaduria General de Cruzada, residente en la villa de Madrid, ausente a este otorgamiento, y el cargo de este poder acceptante para que en mi nombre haga quantas gestiones fuesen oportunas para el percibo en en [sic] la Tesoreria Mayor de su majestad o en las de Exercito de qualesquiera ynteres que pueda corresponderme firmando los recivos o liquidaciones que se necesitaren $=$ Otrosi para que pueda cobrar los yntereses que puedan corresponderme en la particion de bienes de mi difunto padre asi en Madrid como en Asturias, interviniendo en ello, y tomando la posesion de lo que me perteneciere, otorgando las cautelas, y mas que fuere de el caso: Otrosi para que pueda cobrar quantos yntereses me correspondan como a heredero de mi difunta madre doña Pabla Cifuentes Prada en el Monte Pio de el Ministerio, y en qualesquiera otra parte, como igualmente todo lo que me perteneciere de mi señor 
hermano don Bernabe de Canga Argüelles formando de lo que perciviere los documentos que se le pidieren: Otrosi para tomar posesion de la caseria de la Reymua situada en el lugar de Roces concejo de Gijon en Asturias que se me ha cedido en pago de lo que me quedo a deber mi difunto padre. Otrosi para administrar las casas, y cobrar sus rentas que me pertenedcan en Madrid como conjunta persona de la señora doña Eulalia Ventades y Ventades: Otrosi para cobrar los reditos de los vales que dicha señora puso: Otrosi para reclamar de los arrendatarios de los cotos de Lindes y Ponton, y de el administrador de los vienes de la Bañesa que me pertenecen como a marido de la doña Eulalia, las rentas y frutos que produgeron: Otrosi para que en razon de lo que va espresado en esta escritura y demas que se ofredca siga todos y qualesquiera pleitos y causas civiles y criminales movidos y por mover asi demandando como defendiendo con qualesquiera personas particulares o comunes, y en ello y cada uno paredca ante su majestad que Dios guarde señores de sus reales consejos, audiencias, $u$ otros jueces, y justicias, que con derecho pueda y deba, y pida y demande, responda, y niegue, requiera, querelle, y proteste, saque escrituras testimonios y otros papeles que me pertenedcan, y los presente o ponga essecciones, decline jurisdicion, pida veneficios de restitucion, presente escrituras, pedimentos,y provanzas: tache, y contradiga lo en contrario, recuse jueces, letrados, y escribanos esprese las causas de las recusaciones, si lo necesitaren, y las jure, pruebe, y aparte de ellas, haga y pida se hagan por las partes comtrarias, y otros que convengan, pida egecuciones, prisiones, secuestros, de consentimientos de solturas, alce envargos, haga ventas o remates de vienes, acete traspasos, tome posesiones, y amparos, concluya pida, y oiga autos, y sentencias, interlocutorios, y difinitivas, consienta lo favorable, y de lo perjudicial apele, y suplique: Siga las apelaciones, y suplicaciones donde con derecho pueda y deba, gane provisiones, y cedulas reales, requisitorias, y mandamientos y los presente, y haga intimar, donde y a quien se dirigieren y ultimamente para que en todo quanto menester fuese conzerniente a otros asuntos pertenecientes al bien y utilidad de mis vienes, e intereses, pueda comparezer en el tribunal que le compitiere, y en el haga todos los actos que fuesen convenientes, pues para todo lo qual cada cosa, y parte con lo incidente, y dependiente le doy poder tan cumplido cual le tengo y el puedo dar, de forma que por falta de el o algún requisito que no estubiere espresado en este poder no ha de dejar cosa por obrar en lo que se le ofreciere, como yo mismo lo haría y hacer podría si presente fuere, con libre, franca y general administración y con facultad de enjuiciar substituirle en uno o mas procuradores, rebocar los substitutos y nombrar otros, y a todos relevo en forma, prometiendo hacer por firme todo cuanto el citado mi apoderado o sus substitutos en fuerza de este poder hicieren. Y a la firmeza obligo todos mis 
vienes havidos y por haver y doy poder a las justicias de su majestad en especial a las que de mis causas puedan y devan conocer, sometiéndome a su jurisdicion, renunciando mi domicilio y otro fuero que de nuevo ganare la ley si convenerit de jurisdictione ómnium judicum, la ultima pragmática de las sumisiones, y demas leyes y fueros de mi favor, y la general del derecho en forma para que me apremien a su cumplimiento como por sentencia pasada en autoridad de cosa juzgada y por mi consentida. Asi lo otorgo en esta ciudad de Peñiscola a los treinta días del mes de abril de mil ochocientos diez y siete siendo testigos Juan Antonio Barreda practicante de escribano y Juan Bautista Pedra vecinos de esta ciudad. Y el otorgante a quien yo escribano doy fee conozco lo firmo $=$ Jose Canga Argüelles = Ante mi don Juan Bautista Llaudis = Concuerda a la letra bien y fielmente este traslado con el original que se halla alargado en sello cuarto mayor en mi registro protocolo de escrituras publicas del presente año autorizadas por mi don Juan Bautista Llaudis escribano real por su majestad (Dios le guarde) de su corte, reynos y señoríos y de cavildo, y corregimiento de esta ciudad de Peñiscola, y de ella vecino (al qual me remito). Y en fee de ello a requerimiento del interesado doy este que signo y firmo en ella a los tres días del mes de mayo año de mil ochocientos diez y siete $=$ En testimonio de verdad don Juan Bautista Llaudis = Nos los escribanos reales del rey nuestro señor (que Dios guarde) públicos, domiciliados y avecindados en esta ciudad de Peñiscola, y villa de Benicarlo en el presente Reyno de Valencia que signamos firmamos y certificamos hacemos fee que don Juan bautista Llaudis de quien viene autorizada la escritura que precede, esta tenido asi mismo por otro de los escribanos públicos reales de esta dicha ciudad; que cuantas escrituras ante el han pasado y pasan se las ha dado y da, y deve dar entera fee, como hecho de escribano publico fiel, legal y de confianza; que el signo lo tenemos por el suyo propio, y el que ordinariamente practica y para que conste damos el presente a los tres días del mes de mayo de mil ochozientos diez y siete = Esta signado Francisco Llorach $=$ Corresponde con el poder original que me fue exivido por dicho don Jose Cancio de esta vecindad, a quien se le debolvi de que doy fee, y a el me refiero; y para que conste a su instancia, yo el infraescrito escribano de su majestad y del Colegio de esta heroica villa de Madrid doy el presente que signo y firmo en ella a diez y siete de febrero de mil ochozientos diez y ocho = Esta signado = Zacarias Delgado [al margen: Substituzion]. En la villa de Madrid a veinte de febrero de mil ochozientos diez y ocho ante mi el infraescrito escribano de su majestad y testigos, don Jose Cancio de esta vecindad a quien doy fee conozco dijo: Que usando del poder de la buelta y sus facultades, en la amplia forma que en el se expresa, las que tiene aceptadas y de nuevo acepta, le substituía y substituyo en don Jose Coello vecino de la ciudad de Oviedo y en 
los procuradores de aquellos juzgados que el mismo elija si hubiese necesidad de enjuiciar a todos y a cada uno insolidum a quienes relevo según lo es por dicho poder, obligo los vienes en el obligados y otorgo substitución en forma que firma siendo presentes por testigos don Isidro Gonzalez, don Estevan de Navia y don Francisco Martinez residentes en esta corte $=$ Jose de Cancio $=$ Ante mi Zacarias Delgado $=$ [al margen: Legalizacion]. Los infraescritos escribanos del rey nuestro señor y del Colegio de esta Corte, damos fee que don Zacarias Delgado por quien están autorizados el testimonio y substitución precedentes es igual escribano de su majestad individuo del propio Colegio, fiel legal y de toda confianza; por lo qual a cuantos documentos autoriza, siempre se ha dado, da y debe dar entera fee y crédito judicial y extrajudicial. Y para que conste lo signamos firmamos y sellamos en Madrid fecha ut retro = Esta signado. Dionisio Perez $=$ Esta signado . Ramon Atienza $=$ Esta signado. Jose Varela $=$ Esta sellado $=\mathrm{Y}$ usando de las clausulas de substitución que contiene dicho poder, y substitución a su favor le substituía y substituyo por lo que respeta a enjuiciar en don Bernardo Gonzalez Alberú procurador de la Audiencia Territorial de esta provincia con las mismas fuerzas que comprende. Asi lo otorgó y firmó siendo testigos don Vicente Gonzalez Alberú, don Jose Maria Alvarez, y don Fernando Ybañez, vecinos de esta ciudad a cuyo otorgante doy fee conozco.

[Firmado: Josef Coello]

Ante mi [Firmado: Francisco Alvarez]

Registrado libro primero numero 2026 folio 269 debe pagar de derecho fixo cuatro reales. Oviedo 29 noviembre de 1821.

Recivi [Firmado: Bernatoco]

[Firmado: Pedro Muñiz Miranda] 